\title{
Privaatrecht en rechtshandhaving
}

\author{
Caroline Cauffman \& Britt Weyts ${ }^{1}$
}

\section{Inleiding}

De 'rechtshandhavingsfunctie' van het privaatrecht is de laatste jaren vooral onder de aandacht gebracht door de Europese Commissie die de privaatrechtelijke handhaving (private enforcement) van het mededingingsrecht wil aanmoedigen. Meer bepaald wil de Commissie natuurlijke en rechtspersonen die nadeel ondervinden van mededingingsrechtelijke inbreuken aansporen om hiertegen in rechte op te treden door de nietigheid te vorderen van overeenkomsten in strijd met het mededingingsrecht en vooral door een vergoeding te vorderen van de schade die zij tengevolge van de schendingen van het mededingingsrecht hebben geleden. ${ }^{2}$ Op deze wijze zouden private (rechts-)personen bijdragen aan de handhaving van het mededingingsrecht, die tot op heden vooral in handen is van de Europese Commissie en de nationale mededingingsautoriteiten. In de mededingingsrechtelijke doctrine wordt uitvoerig gedebatteerd omtrent de wenselijkheid van dit initiatief van de Europese Commissie en omtrent de wijze waarop nader vorm zou kunnen worden gegeven aan de privaatrechtelijke handhaving (zie 2.3).

In Nederland breidde deze discussie zich de afgelopen jaren uit tot een algemeen privaatrechtelijk debat over de vraag die het privaatrecht kan en mag spelen bij de rechtshandhaving en hoe dat dient te geschieden. ${ }^{3}$ In de recente Belgische privaatrechtelijke doctrine is het hieromtrent in vergelijking met Nederland nog relatief stil gebleven. Toch is er ook in België reeds heel wat werk verricht op dit terrein. Bocken publiceerde reeds in de jaren 1970 over de vraag of het aansprakelijkheidsrecht naast of in plaats van het administratief recht kan bijdragen tot het bewerkstelligen van een optimale zorg voor het milieu. ${ }^{4}$ In de jaren I980 stelde Stuyck de verhouding tussen het strafrecht en het privaatrecht bij de handhaving van het levensmiddelenrecht

I. Caroline Cauffman is docent aan de Universiteit Antwerpen, Universitair docent aan de Universiteit en Advocaat; Britt Weyts is docent aan de Universiteit Antwerpen en Advocaat.

2. Groenboek - Schadevorderingen wegens schending van de communautaire antitrustregels (SEC(2005)I732) $/{ }^{\star} \mathrm{COM} / 2005 / 0672$ def., www.eurlex.europa.eu/LexUriServ/LexUriServ.do?uri= COM:2005:0672:FIN:NL:HTML; Witboek betreffende schadevergoedingsacties wegens schending van de communautaire mededingingsregels, $\operatorname{COM}(2008) \mathrm{I} 65,2.4 .2008$, www.ec.europa.eu/ comm/competition/antitrust/actionsdamages/files_white_paper/whitepaper_nl.pdf.

3. Zie bijv. J. Kortmann, The Tort Law Industry, Amsterdam, Vossiuspers Uva, 2009, 32 p.; Themanummer WPNR oktober 2008 en de referenties in het Nederlandse preadvies.

4. Zie H. Bocken, 'Aansprakelijkheidsrecht en milieubescherming', RW I973-74, II2I-II50; -, 'Sanctions de droit civil centre la pollution', T.Aann. I975, 67-89; -, Preventie, toerekening en herstel van schade door milieuverontreiniging. Preadvies voorde Nederlandse Vereniging voor Rechtsvergelijking, Deventer, Kluwer, I983, I2I p . 
aan de orde. 5 Vanaf de jaren 1990 speelde van Gerven een voortrekkersrol in het debat omtrent de privaatrechtelijke afdwinging van het mededingingsrecht (zie 2.3). In 2004 verscheen vervolgens het doctoraat van Lierman over Voorzorg, preventie en aansprakelijkheid. ${ }^{6}$ Meer recent wijdden Cornelis en Gilliams een tweetal bijdragen aan de privaatrechtelijke handhaving van het mededingingsrecht in België,7 onderzochten een aantal processualisten de mogelijkheid van collectieve acties ${ }^{8}$ en stelden de auteurs van dit preadvies zich de vraag naar de wenselijkheid van een meer punitief verbintenissenrecht. ${ }^{9}$

\section{Privaatrechtelijke rechtshandhaving}

\section{I.I Wat bedoelt men met privaatrechtelijke rechtshandhaving?}

Wanneer men discussieert over de wenselijkheid van 'privaatrechtelijke handhaving' van bijvoorbeeld het mededingingsrecht of het milieurecht dan vertrekt men vaak van de vraag of het privaatrecht een geschikt middel is tot handhaving van reeds in het publiekrecht verwoorde gedragsnormen.

Soms gaat men evenwel nog een stap verder en stelt men zich de vraag of het, gezien het voorhanden zijn van algemene privaatrechtelijke leerstukken zoals de verplichting tot levering van een conforme zaak aan een consument, de productaansprakelijkheid, de leer van de burenhinder en de onrechtmatige daad, nog wel nodig is om bepaalde publiekrechtelijke regels te formuleren. Is het wel nodig om veiligheidsvoorschriften op te leggen voor speelgoed, wanneer we voor ogen houden dat speelgoed dat lichamelijke schade veroorzaakt aan een spelend kind niet geschikt is voor het gebruik waarvoor het is bestemd en tevens een veiligheidsgebrek vertoont en dus aanleiding kan geven tot vorderingen wegens niet-conformiteit en productaansprakelijkheid? Zullen deze vorderingen op zichzelf niet voldoende afschrikwekkend zijn om de producent tot de nodige zorg te bewegen bij de productie? Is het wel nodig om geluidsnormen op te leggen indien de buren van een lawaaierige onderneming tegen overmatige overlast kunnen optreden op grond van burenhinder?

5. J. Stuyck, 'Enkele beschouwingen over de respectieve rol van strafrecht en privaatrecht bij de handhaving van het levensmiddelenrecht', Panopticon 1982, 193-203.

6. S. Lierman, Voorzorg, preventie en aansprakelijkheid, Antwerpen, Intersentia, 2004, XXIII, +605 p.

7. H. Gilliams en L. Cornelis, 'Private enforcement of the competition rules in Belgium', TBM 2007, afl. 2, II e.v.; -, 'Private enforcement of the competition law in Belgium: two current issues' in J. Stuyck, W. Devroe en P. Wytinck (eds.), De nieuwe Belgische Mededingingswet 2006, Mechelen, Kluwer, 2007, 235-252.

8. G. Closset-Marchal en J. van Compernolle, Naar een "class action" in het Belgisch recht?, Brugge, die Keure, 2008, XI+200 p.

9. C. Cauffman, 'Naar een punitief verbintenissenrecht? Een rechtsvergelijkende studie naar de draagwijdte, de grondwettigheid en de wenselijkheid van het bestraffende karakter van het verbintenissenrecht', TPR 2007, 799-873; B. Weyts, 'Lucratieve fouten in het aansprakelijkheidsverzekeringsrecht. The winner takes it all', RW 2005-06, I64I-I652. 
Ook privaatrechtelijke rechtsnormen worden uiteraard (overwegend) door middel van privaatrechtelijke rechtshandhavingsmechanismen gehandhaafd.

Het concept van de privaatrechtelijke rechtshandhaving lijkt daarom te moeten worden uitgebreid tot de handhaving door middel van privaatrechtelijke rechtsfiguren van rechtsnormen in het algemeen en zelfs van nog niet expliciet in het objectieve recht verwoorde, sociaal wenselijke gedragsnormen. Eigen aan privaatrechtelijke rechtshandhavingsmechanismen is bovendien dat de handhaving niet noodzakelijk op initiatief van overheidsorganen dient te geschieden, maar ook mogelijk is op initiatief van bepaalde privaatrechtelijke (rechts-)personen.

Een nog verdergaande privatisering van de rechtshandhaving vindt plaats wanneer men het overlaat aan private organisaties als brancheorganisatie om gedragscodes op te stellen en de naleving hiervan af te dwingen via private, niet door de overheid georganiseerde geschillencommissies en niet voor de 'gewone' rechtbanken. Deze extreme vorm van private handhaving wordt hier terzijde gelaten.

\section{I.2 Verhouding privaatrecht - publiekrecht}

Het uitgangspunt is eenvoudig. Het publiekrecht strekt tot bescherming van het algemeen belang, terwijl het privaatrecht strekt tot bescherming van de subjectieve rechten van particulieren in hun wederzijdse betrekkingen. ${ }^{\text {IO }}$ Het publiekrecht is meer bepaald gericht op het ex ante opleggen van regels tot bescherming van het algemeen belang en de preventie van rechtsschendingen en op het ex post bestrijden van inbreuken op het algemeen belang door middel van administratieve of strafrechtelijke maatregelen die gericht zijn op het doen ophouden van schendingen van het objectief recht en/of op het opleggen van leed aan de dader. ${ }^{\text {II }}$

In het privaatrecht gaat het voornamelijk, zo oordeelt men, om het ex post ongedaan maken van hetgeen ten onrechte is geschied (nietigheid, ontbinding) of om het vergoeden van de daardoor veroorzaakte schade, niet meer maar ook niet minder.

Ten aanzien van de erkenning van de preventieve en punitieve functie van het privaatrecht bestaat meer weerstand. Helemaal weg te denken uit het privaatrecht zijn ze echter niet. In eerdere bijdrage stelden wij reeds een aantal punitieve elementen in het privaatrecht aan het licht. ${ }^{12}$ In deze bijdrage willen wij aantonen dat het privaatrecht ook ter preventie van rechtsschendingen (van subjectieve rechten die echter vaak ook een schending van het objectief recht impliceren) wordt ingezet. Ook de privaatrechtelijke regels van openbare orde of van dwingend recht zijn immers gericht op het ex ante opleggen van regels. Bij regels van louter dwingend recht gaat het dan weliswaar slechts om regels ter bescherming van private belangen, maar

Io. Vgl. HvJ EG I4 december 2000, Masterfoods, C-344/98, Jur. 2000, I-II369, NJ 200I, 430, nr. 22; A.M.A.P. Van Den Bossche, 'De privaatrechtelijke handhaving van Europese mededingingsregels', in A.S. Hartkamp, C.H. Sieburgh en L.A.D. Keus (eds.), De invloed van het Europese recht op het Nederlandse privaatrecht, Deventer, Kluwer, 2007, nr. Io, p. 2 I6.

II. De exante, ex post terminologie is ontleend aan W.H. van Boom, "On the Intersection Between Tort Law and Regulatory Law - A Comparative Analysis in W.H. van Boom, M. Lukas en C. Kissling (eds.), Tort Law and Regulatory Law, Wenen, Springer, 2007, 424 e.v.

I2. C. Cauffman, o.c., TPR 2007, 799-873; B. Weyts, o.c., RW 2005-06, I64I-I652. 
bij regels van openbare orde gaat het evenzeer als in het publiekrecht om regels ter bescherming van het algemeen belang. Regels van aanvullend recht kunnen door de partijen worden wegbedongen, maar zolang dat niet is gebeurd, leggen ook zij regels op, weliswaar slechts gericht op de bescherming van private belangen. Ook overeenkomsten zijn overigens, tussen de contracterende partijen en ter bescherming van hun private belangen, gericht op het ex ante opleggen van regels. De ex post remedies van nietigheid en ontbinding en vooral van schadevergoeding kunnen bovendien ontradend werken en rechtsschendingen voorkomen.

\section{I.3 Handhaving als doel of als 'bijproduct'}

Nietigheid en ontbinding doen onrechtmatige elementen uit het rechtsleven verdwijnen en dragen aldus bij tot handhaving van de rechtsorde. Schadevergoeding compenseert onrechtmatig aangerichte schade. Is het privaatrecht echter ook een geschikt middel tot preventie van sociaal onwenselijk gedrag? Tegenstanders van de (preventieve) privaatrechtelijke handhaving beantwoorden deze vraag negatief. Zij wijzen erop dat het publiekrecht qua handhaving een aantal mogelijkheden biedt die het privaatrecht ontbeert: er kunnen ex ante vereisten worden gesteld in de vorm van vergunningen, er kunnen opsporingstechnieken worden gehanteerd die in het privaatrecht niet toegelaten zijn, er kunnen straffen worden opgelegd waarvan de zwaarte kan worden afgestemd op de ernst van de inbreuk en op de persoon van de dader, ... Zelfs principiële tegenstanders van de handhaving van bepaalde gedragsnormen via het privaatrecht zijn soms evenwel bereid om de preventieve of zelfs punitieve functies van het privaatrecht te erkennen, maar dan niet als een doel, doch slechts als een 'bijproduct', als toevallig gevolg van de uitwerking van het privaatrecht. ${ }^{13}$

De vraag of rechtshandhaving een doel is of een bijproduct van de uitoefening van privaatrechtelijke rechten vereist een genuanceerd antwoord. Een particulier die een subjectief privaatrechtelijk recht uitoefent, streeft veelal in eerste instantie de handhaving na van zijn subjectief recht en niet van het algemeen belang. Het privaatrecht is in essentie inderdaad gericht op de bescherming van subjectieve rechten. Het privaatrechtelijk optreden zal evenwel veelal ook als 'bijproduct' hebben dat er een sanctie is op de overtreding van een objectieve rechtsregel in een bepaald geval en van (de mogelijkheid van) die sanctie zal een preventieve werking uitgaan die kan leiden tot een grotere naleving van het objectief recht en een groter respect voor subjectieve rechten in de toekomst. Dit 'bijproduct' zal in vele gevallen inderdaad ontoereikend blijken te zijn om op zichzelf in te staan voor een afdoende handhaving van het objectief recht op een bepaald domein en a fortiori voor het tot stand brengen van sociaal wenselijk gedrag in de afwezigheid van concrete objectieve rechtsregels. De privaatrechtelijke handhaving zal de publiekrechtelijke handhaving daarom in vele gevallen niet kunnen vervangen. Maar, indien men erkent dat

I3. J.S. Kortmann en C.R.A. Swaak, 'The EC White paper on antitrust damage actions: why the member states are (right to be) less than enthusiastic', ECLR 2009, 34I. 
het privaatrecht handhaving als 'bijproduct' heeft, dan is er niets dat belet, en is het integendeel aangewezen om die handhavingsfunctie van het privaatrecht openlijk te erkennen en mede in aanmerking te nemen bij het uitstippelen van een globaal handhavingsbeleid. De privaatrechtelijke handhaving kan dan een nuttige rol spelen ter aanvulling van de publieke handhaving. ${ }^{4}$

Vervolgens rijst de vraag of de overheid een stap verder kan gaan en de burgers effectief kan aansporen om hun subjectieve rechten te effectueren met het oog op het verhogen van het globale handhavingsniveau van het objectief recht. Voor zover daarbij geen nieuwe privaatrechtelijke handhavingsmechanismen worden gecreeerd, gaat het slechts om de bewustmaking van de burger van de subjectieve rechten die hij heeft en dit kan niet anders dan positief worden beoordeeld.

Nog verder gaat de vraag of het geoorloofd is bijkomende privaatrechtelijke handhavingsmechanismen te creëren met het oog op een hoger globaal handhavingsniveau. Het antwoord op deze vraag hangt uiteraard af van de concrete aard van de in te voeren privaatrechtelijke handhavingsmechanismen. Het meest actueel is thans de vraag naar de wenselijkheid van de invoering van collectieve acties die het mogelijk maken om vorderingen die wegens hun geringe omvang op zichzelf niet leefbaar zijn te bundelen en naar de vraag of bepaalde groeperingen met rechtspersoonlijkheid het recht moeten krijgen om op te treden ter bescherming van bepaalde collectieve belangen. Op zich lijken deze initiatieven te leiden tot een democratisering van de toegang tot het recht en zijn ze daarom positief te beoordelen. Wel dienen uiteraard de nodige maatregelen te worden genomen om misbruiken te voorkomen (bijv. d.m.v. weldoordachte regels m.b.t. de financiering van vorderingen).

Als de privaatrechtelijke handhaving een niveau bereikt dat publieke handhaving overbodig maakt, dan is er ook niets op tegen om bepaalde overbodig geworden publieke handhavingsmechanismen af te bouwen (zoals dat bijvoorbeeld gebeurde bij de depenalisatie van de inbreuken op de eerlijke handelsgebruiken tussen concurrenten, zie 2.4.I). Op de domeinen waar de privaatrechtelijke handhaving thans vooral ter discussie staat (mededingingsrecht sensu stricto en consumentenrecht) is het evenwel niet waarschijnlijk dat dit zal gebeuren. Wat uiteraard niet zou kunnen, is het als overheid wetens en willens laten voortbestaan van een handhavingstekort onder het voorwendsel dat er afdoende privaatrechtelijke handhavingsmechanismen ter beschikking staan aan de rechtsonderhorigen terwijl deze om diverse redenen niet geneigd of in staat zijn van deze mechanismen gebruik te maken (bijv. om reden van het risico en de kost van de procedure in verhouding tot het te verwachten voordeel of om reden van het ontbreken van afdoende opsporingsmogelijkheden).

I4. In deze zin ook Witboek betreffende schadevergoedingsacties, 4; J. Stuyck, 'Public and private enforcement in consumer protection: general comparison EU-USA. Enforcement of Consumer Rights and Legal Redress for Consumers in the EU: An Institutional Model', in F. Cafaggi en H.-W. Micklitz (eds.), New Frontiers in Consumer Protection. The Interplay between Private and Public Enforcement, Antwerpen, Intersentia, 2009, 77-78. 


\section{I.4 Afbakening van het onderwerp}

In wat volgt onderzoeken wij in hoeverre er thans in het Belgische recht ruimte is voor privaatrechtelijke rechtshandhaving. Hierbij belichten wij eerst de meest klassieke en algemene middelen van rechtshandhaving in het privaatrecht: voor het rechtshandelingen- en overeenkomstenrecht spitsen wij ons vooral toe op de nietigheid, voor het buitencontractuele aansprakelijkheidsrecht op de klassieke foutaansprakelijkheid. Daarna bestuderen we een aantal 'bijzondere rechtsdomeinen' en geven wij aan in welke mate daar gebruik wordt gemaakt van privaatrechtelijke handhavingsmechanismen. Meer bepaald bestuderen wij het mededingingsrecht, het recht inzake handelspraktijken, het antidiscriminatierecht, het milieurecht en de intellectuele rechten.

\section{Overzicht van deelgebieden waarbinnen privaatrechtelijke handhaving aan de orde is}

\section{I Algemeen overeenkomstenrecht}

\subsubsection{Algemeen}

Dat de klassieke contractuele remedies (uitvoering in natura, ontbinding, schadevergoeding, exceptio non adimpletu contractus) strekken tot handhaving van de regels van het contractenrecht tussen de contracterende partijen staat buiten kijf. Deze regels worden hierna slechts terloops aan de orde gesteld.

Veel interessanter is de vraag of het contractenrecht ook regels of rechtsfiguren kent die gebruikt kunnen worden tot handhaving van als het ware 'buiten het contract' staande normen. Dit is inderdaad het geval. In het voorgaande wezen wij er reeds op dat de vordering wegens niet-conforme levering/verborgen gebreken ertoe zal bijdragen dat de handelaar/producent geen schadelijke producten op de markt zal brengen.

De tienjarige aansprakelijkheid van de aannemer en architect voor stabiliteitsbedreigende gebreken in bouwwerken is van openbare orde, precies omdat deze regel niet alleen strekt tot bescherming van de private belangen van de bouwheer, maar ook tot bescherming van de openbare veiligheid. Hij moet de aannemer en architect ertoe aansporen voldoende zorgvuldigheid aan de dag te leggen, teneinde schadegevallen door instorting te voorkomen. ${ }^{15}$

Ook andere rechtsfiguren uit het contractenrecht kunnen worden gehanteerd met het oog op handhaving van andere dan louter 'contractuele rechten'. Zo kunnen

I5. H. De Page, Traité élémentaire de droit civil belge, IV, Les principaux contrats (première partie), Brussel, Bruylant, I972, nr. 892, p. I032-I033; P.A. Foriers, 'La responsabilité de l'entrepreneur après réception. Réflexions à propos de l'arrêt de la Cour de cassation du 25 octobre I985', T.Aann. I988, 26r e.v. Vgl. Cass. 5 mei 1967, RW 1967-68, 75, Arr.Cass. 1967, I079, JT 1967, 59I en Pas. 1967, I, 1046. Kritisch: G. Baert, Aanneming van werk, Antwerpen, Story-scientia, 200I, nr. I403 e.v., p. 470 e.v. 
de leer van het aanbod en de verplichting om overeenkomsten te goeder trouw uit te voeren soms soelaas bieden ter bestrijding van discriminatoire praktijken bij de sluiting en uitvoering van overeenkomsten. Aangezien een aanbod, tenzij het anders bepaalt, resulteert in een overeenkomst door de loutere aanvaarding ervan, zal de aanbieder niet meer aan de sluiting van de overeenkomst kunnen ontkomen wanneer hij vaststelt dat zijn in algemene termen geformuleerd aanbod is aanvaard door een persoon met wie hij om discriminatoire redenen niet wenste te contracteren. Wanneer een verhuurder gebruik maakt van een hem toekomend recht om de huurovereenkomst op te zeggen, maar hij dit recht uitoefent met de bedoeling om een persoon te discrimineren op grond van bijvoorbeeld zijn godsdienst, dan zal de rechter op grond van de verplichting tot uitvoering te goeder trouw van overeenkomsten (die in België samenvalt met de leer van het rechtsmisbruik in contractuele aangelegenheden) aan deze opzegging haar uitwerking kunnen ontzeggen. ${ }^{16}$

De meest klassieke vorm van handhaving van regels van openbare orde of dwingend recht door middel van het contractenrecht, bestaat in de nietigheid van hiermee strijdige overeenkomsten. Zij wordt hierna uitvoerig toegelicht.

\subsubsection{Nietigheid}

De handhaving van de regel dat privaatrechtelijke rechtshandelingen geen afbreuk mogen doen aan regels van openbare orde, goede zeden en dwingend recht wordt verzekerd door privaatrechtelijke rechtshandelingen die hier wel afbreuk aan doen nietig te verklaren. De nietigheid dient steeds in rechte te worden te worden. ${ }^{17} \mathrm{Wie}$ de nietigheid kan vorderen verschilt naargelang het gaat om een absolute dan wel een relatieve nietigheid. Dit onderscheid werken wij hierna verder uit. Tevens gaan wij nader in op de gevolgen van de nietigheid.

\subsubsection{Absolute nietigheid}

Artikel 6 B.W., bepaalt dat 'aan de wetten die de openbare orde en de goede zeden betreffen (...) door bijzondere overeenkomsten geen afbreuk (kan) worden gedaan'. De regels die de openbare orde en de goede zeden betreffen zijn volgens de vaste rechtspaak van het Hof van Cassatie de 'regels die de essentiële belangen van de

I6. Zie hierover nader A. Van Oevelen en C. Cauffman, 'Contractsvrijheid, contractweigering en antidiscriminatie' in Bijzondere overeenkomsten 2007-2008, XXXIVste postuniversitaire cyclus Willy Delva, Mechelen, Kluwer, 2008 , nr. 35 e.v., p. 456 e.v. met verdere verwijzingen.

I7. S. Stijns, 'Nietigheid van het contract als sanctie bij zijn totstandkoming', in J. Smits en S. Stijns (eds.), Totstandkoming van de overeenkomst naar Belgisch en Nederlands recht, Antwerpen, Intersentia, 2002, 227 e.v. 
Staat of de gemeenschap raken of in het privaatrecht de juridische grondslagen bepalen waarop de economische of morele orde van de maatschappij rust'. ${ }^{18}$

Overeenkomsten waarvan het voorwerp bestaat in het verrichten van een handeling in strijd met de openbare orde of de goede zeden, of waarvan de doorslaggevende beweegreden, de oorzaak, daarmee in strijd is, zijn absoluut nietig. ${ }^{19}$ Deze nietigheid kan door eenieder worden opgeworpen en zelfs door de rechter ambtshalve. ${ }^{20}$

\subsubsection{Relatieve nietigheid}

Rechtshandelingen die tot stand gekomen zijn met schending van regels die gericht zijn op de bescherming van private belangen van zwakkere contractspartijen zijn relatief nietig. ${ }^{2 \mathrm{I}}$ De relatieve nietigheid kan enkel door de beschermde partij worden opgeworpen. Deze is bovendien niet verplicht de nietigheid op te werpen. Eens de overeenkomst tot stand gekomen is en de beschermde partij zich bewust geworden is van het gebrek dat eraan kleeft, kan de beschermde partij de overeenkomst bovendien uitdrukkelijk of stilzwijgend bevestigen, waardoor zij van haar gebrek wordt ontdaan. ${ }^{22}$

\subsubsection{Gevolgen van de nietigheid}

De nietigheid is in principe een kwestie van alles of niets: ofwel bestaat een rechtshandeling en heeft zij volledige uitwerking, ofwel is ze nietig en heeft ze geen enkele uitwerking: quod nullum est, nullum producit effectum.

De mogelijkheid om de nietigheid te beperken tot een bepaald beding van een overeenkomst is niet op een algemene wijze geregeld door het Burgerlijk Wetboek. Een zekere algemene leer van de partiële nietigheid is wel door de rechtspraak opgebouwd rondom het criterium van de deelbaarheid van het nietige beding ten aanzien van de rest van de overeenkomst. ${ }^{23}$ Of er deelbaarheid is, of een nietig deel van de overeenkomst van de overeenkomst afsplitsbaar is, wordt in de eerste plaats bepaald door de bedoeling der partijen, die de rechter dient te achterhalen aan de hand van de gemeenrechtelijke interpretatietechnieken. ${ }^{24}$ De wil van de partijen dient evenwel te

I8. Cass. 9 december I948, Arr.Verbr. I948, 6I5, Pas. I948, I, 699, noot en RCJB I954, 25I, noot P. De Harven; Cass. Io november 1978, Arr.Cass. 1978-79, 299, noot, Pas. 1979, I, 309, noot en RW I979-80, I479, noot A. Van Oevelen. Zie ook: Cass. Io maart I994, Arr.Cass. I994, 236, noot, Pas. 1994, I, 237, noot, RW I994-95, 43I, JT I994, 4I9, R. Cass. I994, 278, noot T. Denys en D. Meulemans, TBH I995, I5, noot F. Glansdorff, TRV I995, I76, noot H. Laga en Rev. Banque 1994, 258, noot A. Bruyneel; Cass. I9 maart 2007, RW 2007-08, 533.

I9. S. Stijns, o.c. in Totstandkoming van de overeenkomst, 229.

20. S. Stijns, o.c. in Totstandkoming van de overeenkomst, 230.

2I. S. Stijns, o.c. in Totstandkoming van de overeenkomst, 229.

22. S. Stijns, o.c., in Totstandkoming van de overeenkomst, 230-23I.

23. Cass. 27 februari 1959, Pas. I959, I, 653, Arr.Verbr. 1959, 493 en Rec. gén. enr. not. 1962, 65, noot. Zie ook Cass. I3 oktober ig6o, Pas. I96r, I, I6o.

24. I. Claeys, 'Nietigheid van contractuele verbintenissen in beweging' in Sancties en nietigheden, Brussel, Larcier, 2003, nr. 56, p. 308. 
wijken voor de bedoeling van de wetgever bij het instellen van de nietigheidssanctie. ${ }^{25}$ Tevens is rekening te houden met het vereiste van rechtszekerheid in hoofde van derden. ${ }^{26}$ In vele gevallen zal het doel van de wetgever beter bereikt worden door hetzij de partiële, hetzij de volledige nietigheid. Indien een overeenkomst bijvoorbeeld een relatief nietige exoneratieclausule bevat, zou de volledige nietigheid van de overeenkomst de door de clausule benadeelde partij immers voor de keuze stellen om hetzij de uitwerking van de exoneratieclausule te dulden, hetzij de volledige overeenkomst te niet te zien gaan. Het is duidelijk dat de bedoeling van de wetgever in dit geval beter benaderd wordt door enkel de clausule nietig te achten en de benadeelde contractspartij het voordeel te gunnen van de overeenkomst terwijl haar wederpartij het voordeel van de ongeldige exoneratieclausule wordt ontzegd. ${ }^{27}$

Partiële nietigheid kan de vorm aannemen van de nietigheid van één der verscheidene in één document opgenomen overeenkomsten die van de andere wordt afgesplitst. ${ }^{28} \mathrm{Zij}$ kan ook de vorm aannemen van de nietigheid van bepaalde bedingen, zoals exoneratieclausules. ${ }^{29}$ In de recente rechtspraak is verder een tendens waar te nemen om bepaalde delen van een beding nietig te verklaren. Zo werd van een contractuele clausule die bepaalde 'De abonnee is verantwoordelijk voor alle schade aan de gebruikte materialen zelfs ten gevolge van heirkracht of overmacht' enkel het gedeelte nietig verklaard dat betrekking had op de verantwoordelijkheid van de abonnee voor schade veroorzaakt door heirkracht of overmacht. ${ }^{30}$ Inzake discriminatie in het arbeidsrecht zijn er precedenten die de nietigheid beperken tot het discriminerende deel van het beding met als gevolg dat het slachtoffer van de discriminatie aanspraak kan maken op dezelfde voorwaarden als de groep ten aanzien waarvan het slachtoffer benadeeld werd, zelfs retroactief. ${ }^{3}{ }^{1}$

25. Cass. I5 mei 200 I (A.R. P99I479N), www.cass.be. Bepaalde auteurs verzetten zich echter tegen een dergelijke 'normatieve' benadering en benadrukken het belang van de wil der partijen, zie I. Moreau-Margrève en P. Delnoy, 'Vente d'immeuble et dissimulation du prix', (noot onder Cass. I8 maart I988), Ann. Dr. Liège I989, 393-394. Anderen zijn van oordeel dat zich inzake absolute nietigheid een normatieve benadering opdringt, terwijl bij de relatieve nietigheid moet worden uitgegaan van de wilsleer, zie R. Kruithof, H. Bocken, F. De Ly en B. De Temmerman, 'Overzicht van rechtspraak (I98I-I992) Verbintenissen', TPR I994, nr. 303, p. 603-604. Echter, ook ten aanzien van met relatieve nietigheid gesanctioneerde clausules lijkt het doel van de wetgever een nuttig richtpunt te zijn bij de beoordeling van de draagwijdte van de nietigheid.

26. E. Dirix, 'Prijsbewimpeling bij verkoop van een onroerend goed', (noot onder Cass. I8 maart I988), RW ig88-89, nr. 6, p. 713.

27. Vgl. I. Claeys, o.c., in Sancties en nietigheden, nr. 6I, p. 3 I0.

28. Zie Cass. I3 oktober ig6o, Arr.Cass. ig6r, I, r6o.

29. Kh. Leuven $\mathrm{I}_{3}$ december 200I, DAOR 2002, afl. 6I-62, I29; Kh. Antwerpen 9 januari I968, RW ig67-68, iogr.

30. Vred. Kraainem 2 augustus I984, T. Agr. R. I987, 226.

3I. Cass. 27 januari I994, Soc. Kron. I994, 75, noot J. Jacqmain; HvJ EG I3 december I989, zaak I02/88, Ruzius -Wilbrink, Jur. I989, 43II en JTT I990, 259I; HvJ EG 27 juni I99o, zaak 33/89, Kowalska, Jur. I990, I-259I en JTT I99I, I27; HvJ EG 7 februari I99I, Nimz, zaak I84/89, Jur. I99I, I-297 en JTT I99I, 346; I. Samoy en Y. Thiery, 'De Wet van 25 februari 2003 ter bestrijding van discriminatie: een eerste kennismaking' in S. Stijns en P. Wery (eds.), Antidiscriminatiewet en contracten, Brugge, die Keure, 2006, Io; I. Verhelst en I. De Wilde, 'De gevolgen van de anti-discriminatiewet voor het arbeidsrecht', NjW 2003, 448. Zie ook J. Hofkens en S. Demeestere, Discriminatierecht in arbeidsverhoudingen, Mechelen, Kluwer, 2003, I35-136. 
De vraag rijst tevens of gedeeltelijke nietigheid werkelijk alleen kan gerealiseerd worden door het wegschrappen van bepaalde woorden uit een beding of overeenkomst, dan wel ook door het als het ware 'intellectueel' reduceren van een bepaalde clausule. In de recente rechtsleer werd gesuggereerd dat met betrekking tot een exoneratieclausule die een contractant zelfs voor eigen bedrog bevrijdt, de nietigheid in sommige gevallen beperkt zou kunnen blijven tot het enkele bedrog, met behoud van exoneratie voor bijv. zware fout. ${ }^{2}$ Dit resultaat werd de facto overigens reeds bereikt in een oud cassatiearrest dat een beding waardoor een mijnbedrijf zich van alle aansprakelijkheid bevrijdde jegens de koper van de bovengrond bij wijze van uitleg geldig achtte in de mate waarin het slechts de aansprakelijkheid uitsloot die uit een normale en rechtmatige bedrijvigheid voortvloeide, met uitzondering van de onrechtmatige schadeveroorzaking. 33 Bepaalde oude rechtspraak aanvaardde overigens niet enkel de reductie van een bijkomende clausule van een overeenkomst, maar zelfs deze van het voorwerp zelf van de verbintenis van de ene partij als sanctie van de immorele, lesionaire oorzaak waardoor de andere partij werd bewogen. Een dergelijke oorzaak is immers slechts gedeeltelijk nietig, namelijk in de mate waarin zij lesionair is. Deze opvatting vond steun bij gezaghebbende auteurs. ${ }^{34}$

De bezwaren tegen reductie zijn van tweeërlei aard. In de eerste plaats voert men aan dat reductie onwenselijk is omdat zij een partij ertoe zou kunnen aanzetten om bedingen op te nemen die de wettelijke grenzen te boven gaan omdat zij toch niet meer te vrezen heeft dan de reductie van het beding. 35 Zo zou een partij geneigd zijn om exoneratiebedingen op te nemen die vrijstellen van elke aansprakelijkheid, inclusief haar eigen bedrog en opzet. Een partij zou daarmee kunnen beogen dat haar juridisch niet-onderlegde wederpartij bij een eventueel opzettelijk veroorzaakt schadegeval van vervolging afziet. Gaat de wederpartij toch tot vervolging over, dan kan zij hoogstens de reductie van het beding bekomen. Indien een overdreven exoneratieclausule evenwel wordt gesanctioneerd met nietigheid, dan zal men daarentegen eerder opteren voor een beperktere, doch geldige exoneratieclausule. Dit bezwaar zou men kunnen ondervangen door van de reductie geen recht te maken, maar een mogelijkheid waarvan de rechter gebruik kan maken indien zulks gelet op de omstandigheden van de zaak en het doel van de geschonden regel gepast lijkt.

Een tweede bezwaar houdt in dat reductie ingrijpt op het synallagma van een overeenkomst. ${ }^{36}$ Het komt, zo zegt men, enkel de partijen toe te bepalen wat de omvang van hun over en weer verschuldigde prestaties en verbintenissen is. De rechter mag hierin niet tussenkomen. Tegen dit bezwaar is vooreerst op te merken dat de hier

32. I. Claeys, o.c. in Sancties en nietigheden, nr. 63, p. 3 I2.

33. Cass. 20 november I9I3, Pas. I9I4, I, 7.

34. A. De Bersaques, 'Le juge peut-il réduire le salaire stipulé par le locateur d'industrie?', (noot onder Kh. Antwerpen I2 januari I953), RCJB I954, I9o e.v.; H. De Page, Le problème de la lésion dans les contrats, Brussel, Office de publicité, I946, I07 en II2; Kluyskens, [La lésion dans les contrats] in Travaux de l'Association Henri Capitant pour la culture juridique française, Parijs, Dalloz, I946, 205.

35. A.S. Hartkamp, Mr. C. Asser's handleiding tot de beoefening van het Nederlands burgerlijk recht, Verbintenissen, 4-II, Algemene leer der overeenkomsten, Deventer, Kluwer 2005, 4-II, nr. 49I, p. 5I8; S.A.M. De Loos-Wijker, 'Art. 4I' in Vermogensrecht, 2002, nr. 6, p. 97-98.

36. Zie BGH 5 juni I989, BGHZ 107, 358; D. Medicus, Allgemeiner Teil. Ein Lehrbuch, Heidelberg, C.F. Müller Verlag, 2002, nr. 505, p. I98. 
bedoelde reductie uiteraard niet leidt tot een invoering van een algemene iustum pretium-regel, doch enkel een vorm is van matiging van de door de wet ingestelde nietigheidssanctie. Ook bij gebreke aan deze vorm van reductie treedt er tengevolge van de nietigheid een wijziging in ten aanzien van het akkoord dat de partijen hebben bereikt, en niet zelden zal de algehele nietigheid een veel meer drastische afwijking inhouden van het akkoord der partijen dan de reductie. Dit neemt niet weg dat het, zeker wanneer de wet zelf geen maximumgrens voorschrijft, niet steeds eenvoudig zal zijn maatstaven te vinden aan de hand waarvan reductie dient plaats te vinden en dat de reductie veelal zal berusten op het soevereine oordeel van de feitenrechter. ${ }^{37}$ Toch is een dergelijke reductie niet geheel vreemd aan ons rechtssysteem. Zo is het bijvoorbeeld algemeen aanvaarde dat de rechter een in zijn ogen excessief loon van een lasthebber kan matigen tot een billijke vergoeding..$^{8}$ Ook de sanctie van de thans algemeen aanvaarde leer van het rechtsmisbruik bestaat in de matiging van de rechtsuitoefening. ${ }^{39}$

De reductie bevindt zich op het raakvlak tussen de partiële nietigheid en de conversie. De rechtsleer die de reductie van overeenkomsten bestudeert, beschouwt deze overwegend als een vorm van partiële nietigheid; $4^{\circ}$ af en toe spreekt men evenwel van conversie, gebruikt men beide termen min of meer door elkaar of wijst men minstens op de enge verwantschap tussen beide. ${ }^{4 \mathrm{I}}$ Zowel partiële nietigheid als conversie zijn technieken tot matiging van de nietigheidssanctie. Grofweg gesteld hanteert men de term 'partiële nietigheid' wanneer een overeenkomst bij wijze van sanctie herleid wordt tot minder dan aanvankelijk het geval was, 'conversie' wanneer een overeenkomst bij wijze van sanctie wordt omgevormd tot een andere dan aanvankelijk het geval was. Partiële nietigheid is m.a.w. kwantitatief, conversie kwalitatief. ${ }^{2}$ Partiële nietigheid wordt over het algemeen aanvaard in het Belgische recht; voor conversie ligt dat een heel stuk moeilijker. In feite dient men een onderscheid te maken tussen de wettelijke, de vrijwillige en de gerechtelijke conversie. Bij wettelijke conversie bepaalt de wetgever zelf welke wijziging een overeenkomst bij wijze van sanctie dient te ondergaan. Indien een handelshuur wordt aangegaan voor een duur van minder dan negen jaar, hetgeen verboden is op grond van artikel 3 lid I Handelshuurwet, dan wordt die van rechtswege op negen jaar gebracht, tenzij de

37. Zie hierover C. Cauffman, 'Vers un endiguement du pouvoir modérateur du juge en cas de nullité?', (noot onder Cass. 23 maart 2006), RCJB 2007, nr. I9 e.v., p. 436 e.v.

38. B. Tilleman, Lastgeving, Antwerpen, Kluwer, I997, nr. 2 Io e.v., p. II3 e.v. en de daar aangehaalde rechtspraak.

39. A. De Bersaques, 'La lésion qualifiée et sa sanction', (noot onder Kh. Brussel 20 februari I970), RCJB I977, nr. 8, p. I6-I7; W. De Bondt, De leer der gekwalificeerde benadeling, Antwerpen, Kluwer, I985, I8I.

40. Ph. Simler, La nullité partielle des actes juridiques, Parijs, LGDJ, I969, nr. 32I, p. 392-393.

4I. J. Ronse, 'Gerechtelijke conversie van nietige rechtshandelingen', TPR I965, 208.

42. Zie hierover wat het Nederlandse recht betreft: S.A.M. De Loos-Wijker, 'Art. 42', Vermogensrecht, nr. I3. 
wederpartij de nietigheid vordert. 43 Bij vrijwillige conversie verrichten de partijen zelf een nieuwe rechtshandeling om de gevolgen van de nietigheid te voorkomen. ${ }^{44}$ Deze twee vormen van conversie worden erkend. Veel meer controversieel is echter de gerechtelijke conversie, waarbij de rechter met de geldige elementen die hij uit een nietige overeenkomst kan destilleren een geldige overeenkomst reconstrueert. Een aanzienlijk deel van de rechtsleer is voorstander van de gerechtelijke conversie omdat zij strookt met de hedendaagse opvatting die een flexibel sanctioneringsbeleid voorstaat en de nietigheid niet verder wil laten reiken dan haar doel noodzakelijk maakt. 45 Andere auteurs weigeren de conversie te erkennen behoudens in de gevallen voorzien door de wet. Zij oordelen dat de conversie buiten die gevallen elke wettelijke grondslag mist en indruist tegen de bedoeling der partijen. ${ }^{46}$ Ook het Hof van Cassatie lijkt de conversie niet genegen. In een arrest van 23 maart 2006 verzette het Hof van Cassatie zich immers tegen de vervanging van een nietig beding door een beding dat niet berust op de wilsovereenstemming der partijen. ${ }^{47}$ De tegenstelling tussen de voor- en de tegenstanders van de conversie wordt wel gemilderd door het feit dat ook de voorstanders van de gerechtelijke conversie vereisen dat de 'aangepaste' rechtshandeling het door de partijen beoogde doel voor zoveel mogelijk moet benaderen $4^{8}$ en dat de partijen niet de bedoeling moeten hebben gehad om die rechtshandeling uit te sluiten. ${ }^{49}$ Bovendien blijkt de noodzaak van een conversie vaak overbodig te worden geacht omdat de rechtbanken een oplossing vinden door de overeenkomst conform artikel II57 BW zodanig te interpreteren dat zij geldig is. ${ }^{50}$

De nietigheid ontslaat de partijen voor de toekomst van de verplichting om de nietige bepaling of clausule na te komen. De nietigheid heeft bovendien retroactieve werking. De nietige bepaling of overeenkomst wordt geacht nooit te hebben bestaan. Al hetgeen in uitvoering van de nietige bepaling of overeenkomst is gepresteerd, moet worden teruggegeven (restitutio status quo ante). In beginsel geschiedt de teruggave in natura. Indien de teruggave in natura niet mogelijk is (bijv. omdat de goederen zijn verwerkt of doorverkocht of omdat het gaat om uitgevoerde diensten die niet kunnen worden ongedaan gemaakt) dan geschiedt de teruggave bij equivalent, dat wil zeggen dat de waarde van het gepresteerde moet worden teruggegeven. Op grond

43. M. Dambre, 'De duur en de beëindiging in onderling akkoord of door opzegging van de handelshuur' in Vijftig jaar toepassing van de Handelshuurwet, Brugge, die Keure, 2002, 33; Y. Merchiers, 'Wilsautonomie en dwingend recht met betrekking tot de duur van de handelshuur en de pacht' in Liber Amicorum Willy Callewaert, Antwerpen, Kluwer, 1984, 52-53. Zie evenwel W. Rauws, Civielrechtelijke beëindigingswijzen van de arbeidsovereenkomst: nietigheid, ontbinding en overmacht, Antwerpen, Kluwer, I987, 52-53 die oordeelt dat het hier gaat om een geval van gerechtelijke conversie.

44. W. van Gerven, Algemeen Deel, in Beginselen van Belgisch privaatrecht, Brussel, Story-Scientia, I987, nr. 134, p. 427.

45. S. Stijns, o.c., in Totstandkoming van de overeenkomst, 253; J. Ronse, 'Gerechtelijke conversie van nietige rechtshandelingen', TPR I965, 22I; W. van Gerven, Algemeen deel, nr. I34, p. 429-430.

46. L. Cornelis, o.c., nr. 573, p. 725-726; W. Rauws, o.c., 49 en 53-54.

47. Cass. 23 maart 2006, RCJB 2007, 422, noot C. Cauffman.

48. S. Stijns, o.c., in Totstandkoming van de overeenkomst, 253.

49. J. Ronse, o.c., TPR I965, 208; W. van Gerven, Algemeen Deel, nr. I34, p. 429-430.

50. J. Ronse, o.c., TPR I965, 204; S. Stijns, o.c., in Totstandkoming van de overeenkomst, 253. 
van het beginsel in pari causa turpitudinis heeft de rechter evenwel de bevoegdheid (niet de plicht!) om een partij het voordeel van de restitutio status quo ante te ontzeggen wanneer hij van oordeel is dat dit voordeel 'de preventieve rol van de sanctie van absolute nietigheid (...) in het gedrang zou brengen, hetzij nog omdat hij meent dat de sociale orde vereist dat een van de medecontractanten zwaarder moet worden getroffen'. ${ }^{\mathrm{I}}$

\subsection{Onrechtmatige daad}

Algemeen wordt aangenomen dat de vergoeding van slachtoffers de basisfunctie is van het buitencontractueel aansprakelijkheidsrecht. ${ }^{2}$ Het slachtoffer dat met succes een aansprakelijkheidsregel aanvoert, zal aldus integraal worden vergoed door de schadeverwekker. ${ }^{53}$ Maar daarnaast kan het aansprakelijkheidsrecht ook andere functies vervullen, zoals het voorkomen van schadegevallen. De dreiging aansprakelijk te worden gesteld zou potentiële schadeverwekkers ervan weerhouden fouten te begaan. Deze preventieve functie wordt evenwel deels ondergraven door de veralgemening van de aansprakelijkheidsverzekering, waardoor de schadeverwekker vaak de schadevergoeding niet zelf moet betalen. 54

Voorts wordt aan het aansprakelijkheidsrecht ook een reglementerende of normatieve functie toegeschreven. Het aansprakelijkheidsrecht vervult een rol in de handhaving en de bescherming van de maatschappelijke orde. Het zorgt enerzijds voor het afdwingen van de naleving van bestaande rechtsregels en leidt anderzijds tot het uitwerken van nieuwe gedragsregels. Op deze wijze wordt voor een deel losgekomen van de concrete schade-eis van een slachtoffer en wordt meer gekeken naar de beïnvloeding van het gedrag van andere personen. 55 Veelal wordt de rol van het aansprakelijkheidsrecht in het handhavingsverhaal beperkt tot een bijrol, nu andere rechtsdomeinen (bijv. het straf- en bestuursrecht) vaak toch als effectiever worden beschouwd..$^{6}$

De regel van de foutaansprakelijkheid blijft de leidraad van het aansprakelijkheidsrecht. Eenieder die op foutieve wijze schade aan een derde berokkent, moet het slachtoffer volledig vergoeden. De wetgever heeft de buitencontractuele fout niet

5I. Cass. 24 september I976, Arr.Cass. I977, 98, Pas. I977, Ior, RW I976-77, 2269, JT I977, 47I en Rev. not. b. I977, 602. Zie ook Cass. 5 september I996, Arr.Cass. I966, 708, Pas. I996, 760, R.Cass. I997, 224, noot I. Claeys; Cass. 8 december 1966, Arr.Cass. 1967, 450, Pas. 1967, 434, concl. Proc.-gen. Hayoit de Termicourt, RCJB I967, 5, noot J. Dabin en RW I967-68, 397; S. Stijns, o.c., in Totstandkoming van de overeenkomst, 255-256. Zie over de gevolgen van de nietigheid uitvoerig T. Starosselets, 'Effets de la nullité' in P. Wéry (ed.), La nullité des contrats, Brussel, Larcier, 2006, 23I e.v.

52. A. Tunc, 'Introduction', in Int.Enc.Comp.Law., XI, Torts, 93.

53. Zie o.a. Cass. I5 mei I94I, Pas. I94I, I, I92; Cass. 23 december I992, Arr.Cass. I992, I466; Cass. 2 november 1999, Arr.Cass. 1999, I363; Cass. 21 december 2001, Arr.Cass. 2001, 2283.

54. T. Vansweevelt en B. Weyts, 'Het buitencontractueel aansprakelijkheidsrecht: situering, doelstellingen, krachtlijnen, kritiek en vooruitzichten', in UALS (ed.), Verantwoordelijkheid en recht, Mechelen, Kluwer, 2008, II3.

55. T. Hartlief, 'Handhaving in het aansprakelijkheidsrecht. Op weg naar een betere samenleving?', WPNR 2008, 769; T. Vansweevelt en B. Weyts, o.c., in Verantwoordelijkheid en recht, II5.

56. T. Hartlief, o.c., WPNR 2008, 77I. 
gedefinieerd. Voormalig Procureur-Generaal P. Leclerq heeft de fout omschreven als de inbreuk op een recht, waardoor bijvoorbeeld de aantasting van het recht op fysieke integriteit of van het recht op bescherming van het patrimonium van een derde, automatisch een fout opleverde. 57 Het Hof van Cassatie heeft aanvankelijk zijn standpunt gevolgd ${ }^{5}$, maar na het vertrek van P. Leclerq werd deze leer verlaten, hoewel hierover betwisting blijft bestaan met betrekking tot de persoonlijkheidsrechten (zie 2.5).

De buitencontractuele fout in de zin van artikel $\mathrm{I}_{3} 82 \mathrm{~B} . \mathrm{W}$. onderstelt een objectief en een subjectief element. ${ }^{59}$ Met het eerste element wordt bedoeld dat de schadeverwekker een onrechtmatige daad moet hebben begaan, die twee vormen kan aannemen. Ten eerste handelt een schadeverwekker onrechtmatig wanneer hij zich niet gedraagt zoals het een normaal, zorgvuldig persoon, geplaatst in dezelfde omstandigheden, betaamt. Het betreft de schending van de algemene zorgvuldigheidsnorm. De rechtspraak aanvaardt ten tweede dat een schadeverwekker onrechtmatig handelt wanneer hij een norm overtreedt, die een bepaalde gedragsregel bevat, hetzij een gebod, hetzij een verbod. ${ }^{60}$ Wanneer aldus een norm een bepaald gedrag gebiedt of verbiedt, is de loutere overtreding van die norm een buitencontractuele fout. ${ }^{6 \mathrm{r}} \mathrm{De}$ onrechtmatige daad kan derhalve gebruikt worden tot handhaving middels compensatieverplichtingen van alle wettelijke gebods- of verbodsbepalingen, waarbij 'wet' is te verstaan in de zin van ieder algemeen verbindend rechtsvoorschrift.

Voorts omvat de buitencontractuele fout een subjectief element. De wilsvrijheid vormt immers de basis van de regel van de foutaansprakelijkheid, die steunt op het idee van schuld. Foutief gedrag onderstelt noodzakelijkerwijze dat de dader de vrijheid had om zich anders te gedragen dan hij deed. ${ }^{62}$ Daartoe moet worden vastgesteld dat de dader op het moment van het schadegeval schuldbekwaam was en dat de daad of het nalaten aan hem kan worden toegerekend. ${ }^{6} 3$

Schuldbekwaamheid betekent dat een dader op het moment van de feiten bekwaam was om zijn handelen te beheersen en zich tevens rekenschap kon geven van de gevolgen van zijn daden. ${ }^{64}$ Letterlijk moet de dader bekwaam zijn om schuld te

57. P. Leclerq, noot onder Cass. 23 juni I932, Pas. I932, I, 200; P. Lerclerq, 'Le conducteur d'une automobile qui tue ou blesse un piéton, commet-il un acte illicite?', RGAR I927, I64.

58. Zie o.a. Cass. I juli I929, Pas. I929, I, 259, met concl. proc.-gen. P. Leclerq; Cass. 23 juni I932, Pas. I932, I, 200.

59. J. Dabin en A. Lagasse, 'Examen de jurisprudence (I939-48). La responsabilité délictuelle et quasi-délictuelle', RCJB I949, 57; X. Thunis, 'Théorie générale de la faute', in J.L. Fagnart (ed.), Responsabilités. Traité théorique et pratique, Diegem, Kluwer, 200I, I9.

6o. Cass. 22 september I988, Arr.Cass. I988-89, 94. Zie F. Swennen, Geestesgestoorden in het Belgische recht, Antwerpen, Intersentia, 2000, 360; H. Vandenberghe, 'Recente ontwikkelingen bij foutaansprakelijkheid', in Themis academiejaar 2007-2008, Aansprakelijkheid-en verzekeringsrecht, Brugge, die Keure, 2008, 46.

6I. R.O. Dalcq, Traité de la responsabilité civile, in Les Novelles, Brussel, Larcier, I962, I78.

62. F. Swennen, Geestesgestoorden in het burgerlijk recht, 363 .

63. R.O. Dalcq, Traité de la responsabilité civile, 728; F. Swennen, Geestesgestoorden in het burgerlijk recht, 363 e.v.; H. Vandenberghe, M. Van Quickenborne, L. Wynant en M. Debaene, 'Overzicht van rechtspraak. Aansprakelijkheid uit onrechtmatige daad (I994-I999)', TPR 2000, I688.

64. P. De Tavernier, De buitencontractuele aansprakelijkheid voor schade veroorzaakt door minderjarigen, Antwerpen, Intersentia, 2006, 32 e.v. 
dragen. De schuldbekwaamheid vormt zo als het ware de voorafgaande voorwaarde om na te gaan of de schuld ook toerekenbaar is aan de dader. ${ }^{65}$ Schuldbekwaamheid onderstelt een onderzoek in concreto naar de persoon van de schadeverwekker zelf. De rechter moet nagaan of hij, rekening houdende met zijn geestelijke capaciteiten, schuldbekwaam was op het moment van de feiten.

Voorts moet de onrechtmatige daad toerekenbaar zijn aan de dader. Hiermee wordt bedoeld dat een schadeverwekker slechts aansprakelijk kan worden gesteld ingeval hij uit vrije en bewuste wil onrechtmatig heeft gehandeld. ${ }^{66}$ Het gaat met andere woorden om kennen en kunnen. ${ }^{67}$ De feitenrechter gaat na of de dader op het moment van de feiten inzicht had in zijn eigen handelen. Daartoe moet de schadeverwekker kunnen beseffen dat hij onrechtmatig handelde zodat hij de mogelijkheid had om zijn gedrag daaraan aan te passen. De feitenrechter is zo verplicht om in elk concreet geval te controleren of de dader begreep welke zorgvuldigheid van hem verwacht werd en of hij zijn gedrag daar heeft aan aangepast. ${ }^{68}$ De leeftijd en de geestesstoornis kunnen in dit verband storend werken, maar ook andere omstandigheden kunnen de vrije wil uitschakelen. Denk bijvoorbeeld aan de schulduitsluitingsgronden.

Het subjectieve element wordt zowel vereist bij de schending van de algemene zorgvuldigheidsnorm alsook bij de inbreuk op een gebods- of verbodsbepaling. ${ }^{69} \mathrm{Het}$ Hof van Cassatie heeft dit onderschreven door in het laatste geval ook uitdrukkelijk te vereisen dat de schending wetens en willens is gebeurd. $7^{\circ}$ Concreet betekent dit dat de dader enerzijds uit vrije wil moet hebben gehandeld en dus vrijwillig de wet moet hebben geschonden. Anderzijds moet hij ook wetens of bewust gehandeld hebben, wat betekent dat hij zich bewust was van de handeling die de schending van de wet inhoudt. Nochtans wil dit niet zeggen dat de schadeverwekker ook daadwerkelijk moest weten dat hij de wet schond. ${ }^{71}$ Wel is het zo dat bij een schending van een specifieke regel het subjectief element wordt vermoed aanwezig te zijn. De bewijslast terzake van het subjectieve element verschuift derhalve naar de dader wiens gedraging slechts dan niet als een fout zal worden beschouwd indien hij bewijst dat hij handelde op grond van een onoverkomelijke dwaling of dat de voorwaarden van enige (andere) grond tot opheffing van aansprakelijkheid zijn vervuld. $7^{2}$

65. G. Jocqué, 'Bewustzijn en subjectieve verwijtbaarheid', in Aansprakelijkheid, aansprakelijkheidsverzekering en andere schadevergoedingssystemen, 6 .

66. F. Swennen, Geestesgestoorden in het burgerlijk recht, 363 e.v.; G. Jocqué, o.c., in Aansprakelijkheid, aansprakelijkheidsverzekering en andere schadevergoedingssystemen, 5 e.v.

67. Vgl. F. Swennen, Geestesgestoorden in het burgerlijk recht, 363 e.v.

68. R.O. Dalcq, Traité de la responsabilité civile, 2307.

69. G. Jocqué, o.c., in Aansprakelijkheid, aansprakelijkheidsverzekering en andere schadevergoedingssystemen, 7 .

70. Cass. 3 oktober 1994, Arr.Cass. I994, 807.

7I. G. Jocqué, o.c., in Aansprakelijkheid, aansprakelijkheidsverzekering en andere schadevergoedingssystemen, 7 .

72. Cass. 8 november 2002, RW 2004-05, I259; W. van Gerven en S. Covemaeker, o.c., 365. Al bestaat enige onzekerheid omtrent de omkering van de bewijslast bij schending van strafrechtelijke bepalingen, zie Cass. Io april I970, Pas. I970, I 682. Hierover B. Dubuisson, 'Faute, illégalité et erreur d'interprétation en droit de la responsabilité civile', (noot onder Cass. 26 juni I998), RCJB 200I, nr. 2I, p. 45-46. 


\subsection{Mededingingsrecht}

\subsubsection{Algemeen}

Het EG-verdrag voorziet uitdrukkelijk in privaatrechtelijke handhaving door overeenkomsten en besluiten in strijd met het kartelverbod van artikel 8I lid I EG nietig te verklaren. De nietigheidssanctie wordt ook toepasselijk geacht op overeenkomsten die misbruik inhouden van een machtspositie in de zin van artikel $82 \mathrm{EG}$. Het is echter vooral de privaatrechtelijke handhaving van de artikelen 8I en 82 door middel van vorderingen tot schadevergoeding die de laatste jaren aanleiding heeft gegeven tot discussie. ${ }^{73}$ In ons land doen ondernemingen die het slachtoffer zijn van inbreuken op het mededingingsrecht bovendien vaak een beroep op de vordering tot staken van de WHPC.

\subsubsection{Nietigheid}

De grondslag voor de privaatrechtelijke handhaving van artikel 8I EG is uitdrukkelijk verwoord in het tweede lid van dit artikel: 'De krachtens dit artikel verboden overeenkomsten of besluiten zijn van rechtswege nietig.' De nietigheid is absoluut. ${ }^{74}$ Artikel 8I EG is immers 'een voor de vervulling van de taken van de Europese Gemeenschap onontbeerlijke bepaling van openbare orde.'75 Vermits de nietigheid absoluut is, kan zij door iedere belanghebbende worden opgeworpen, zelfs door de contractspartij die verantwoordelijk is voor het opnemen van de verboden clausule in de overeenkomst, ${ }^{7}$ en zelfs (wanneer het nationale recht het toelaat, en dat is in België het geval) door de rechter ambtshalve. 77 De absolute nietigheid wegens schending van artikel 8I, lid I EG geldt $a b$ initio. Zij kan volgens het Hof van Justitie 'alle gevolgen, voor het verleden en voor de toekomst, van de overeenkomst of het besluit (...) treffen'. ${ }^{8}$ De nietigheid op grond van artikel 8I lid 2 EG is echter beperkt tot de contractuele clausules die onverenigbaar zijn met artikel 8I lid I EG. Zij 'treft de overeenkomst slechts in haar geheel indien de bedingen die onverenigbaar zijn met artikel 8I, lid I, niet van de overeenkomst zelf kunnen worden losgekoppeld. In het omgekeerde geval worden de gevolgen van de nietigheid voor alle andere onderdelen van

73. In het spoor daarvan wordt een gelijkaardig debat gevoerd over de private handhaving van de staatssteunregels. Dit wordt hier evenwel terzijde gelaten.

74. HvJ EG 25 november I97I, Béguelin, zaak 22/7I, Jur. I97I, 949; A.M.A.P. Van Den Bossche, o.c., in De invloed van het Europese recht op het Nederlandse privaatrecht, nr. 36, p. 230.

75. HvJ EG 4 juni 2009, zaak C-8/o8, T-Mobile Netherlands BV, e.a. t/ Raad van bestuur van de Nederlandse Mededingingsautoriteit, www.curia.eu.

76. HvJ EG 20 september 200I, Courage, C-453/99, Jur. 200I, I-6297, nr. 24. Zie reeds Adv.-Gen. Mayras in zijn conclusie in zaak 59/77, De Bloos II, Jur. I977, 2376.

77. HvJ EG 4 juni 2009, zaak C-8/08, gecit.; HvJ EG I4 december I995, gevoegde zaken C-430/93 en C-43I/93, Jur. 1995, I-4705. Zie ook H. Gilliams en L. Cornelis, o.c.., TBM 2007, afl. 2, nr. 8, p. I4; A.M.A.P. Van Den Bossche, o.c., in De invloed van het Europese recht op het Nederlandse privaatrecht, nr. 36, p. 230.

78. HvJ EG 6 februari I973, Haecht II, 48/72, Jur. I973, 77, r.o. 26. Zie ook HvJ EG I3 juli 2006, Manfredi e.a., gevoegde zaken C-295-04 t/m C-298/04, Jur. 2006, I-66I9. 
de overeenkomst niet door het gemeenschapsrecht bepaald'.79 Die gevolgen moeten dan naar nationaal recht worden beoordeeld. ${ }^{80}$ Naar Belgisch recht zal de nietigheid van een bepaalde clausule van een overeenkomst slechts leiden tot de nietigheid van de gehele overeenkomst indien de verboden clausule met de overeenkomst in een onverbrekelijk verband staat (zie 2.I.5).

De nietigheid wegens strijdigheid met artikel 8I lid 2 EG werd herhaaldelijk opgeworpen voor de Belgische rechtbanken, ${ }^{8 \mathrm{I}}$ in het bijzonder in verband met exclusieve drankafnameovereenkomsten tussen brouwers en caféhouders. ${ }^{82}$

Artikel 82 EG verklaart misbruik van machtspositie 'onverenigbaar met de gemeenschappelijke markt en verboden' maar vermeldt niet uitdrukkelijk dat overeenkomsten die worden gesloten met misbruik van machtspositie nietig zijn. Artikel 82 EG heeft wel directe werking. Het wordt ook ondenkbaar geacht dat een onderneming met een machtspositie een clausule in een overeenkomst die een misbruik van machtspositie inhoudt in rechte zou kunnen afdwingen. Het wordt echter niet uitgesloten dat een dergelijke clausule tegen de dominante onderneming zou kunnen worden afgedwongen. ${ }^{3}$ Zoals bij artikel 8I EG wordt aangenomen dat de strijdigheid met artikel 82 EG van een bepaalde contractuele clausule, die niet in een onverbrekelijk verband staat met de rest van de overeenkomst, enkel de nietigheid van de betreffende clausule impliceert tenzij het nationale recht verdergaande gevolgen toeschrijft aan de nietigheid. ${ }^{8}$ In België is dat niet het geval.

De nietigheid wegens strijdigheid met artikel 82 EG blijkt slechts zelden te zijn opgeworpen voor de Belgische rechtbanken. ${ }^{8}$ Uit een arrest van het hof van beroep van Brussel van 3 november 2005 met betrekking een prejudiciële vraag inzake de verzoenbaarheid van een door Sabam georganiseerd systeem van gedifferentieerde tarificatie met artikel 82 EG blijkt dat de schending van artikel 82 werd opgeworpen

79. HvJ EG II september 2008, CEPSA, zaak C-279/06, Pb C 8 november 2008 (dispositief), afl. $285,4$. Zie ook reeds HvJ EG I4 december I984, Ciments et bétons, zaak 319/82, Jur. I983; 4I73; HvJ EG I8 december I986, VAG, zaak C-Io/86, Jur. I986, 407I; HvJ EG 28 januari I99I, Delimitis, zaak C-234/89, Jur. I99I, 935; HvJ EG 30 juni I966, STM/ Maschinenbau ULM, zaak 56-65, Jur. Ig66, 392.

8o. Art. 8I lid 3 Richtsnoeren, 4I; HvJ EG I8 december I986, VAG France, zaak C-Io/86, Jur. I986, 407I, nr. I4; HvJ EG I4 december I983, Société de Vente de Ciments/Kempen, 319/82, Jur. I983, 4I73, nr. I2; HvJ EG 30 juni ig66, STM/Maschinenbau ULM, zaak C-56/65, Jur. I966, 392.

8I. Gent 5 maart 2007, TBM 2008, afl. 2, 23, noot H. Burez (beroep op nietigheid wegens schending van artikel 8I EG-verdrag als verweer tegen een vordering tot staking gesteund op derdemedeplichtigheid aan contractbreuk).

82. Zie bijv. Antwerpen I4 maart 2006, TBM 2006, 328 en Antwerpen 7 november 2006, TBM 2007, 90. De arresten Brasserie de Haecht/ Wilkin en Janssen, HvJ EG I2 december I967, Haecht I, zaak 23/67, Jur. 1967, 512 en 6 februari 1973, Haecht II, 48/72, Jur. 1973, 77 betroffen overigens een Belgische brouwerij. Zie ook Brussel 23 juni 2006, www.ec.europa.eu/comm/competition/antitrust/ actionsdamages/files_white_paper/whitepaper_nl.pdf.

83. A.P. Komninos, EC Private Antitrust Enforcement, Oxford, Hart, 2008, r6o; R. Whish, Competition Law, Oxford, University Press, 2003, 296; A. Jones en B. Sufrin, EC Competition Law., Oxford, Oxford University Press, 2008, I325. Zie ook A-G Warner in Greenwich Film Production, Jur. I979, 3275 .

84. R. Whish, o.c., 296.

85. H. Gilliams en L. Cornelis, o.c., TBM 2007, afl. 2, nr. 5, p. I3. 
als verweer tegen een door Sabam ingestelde eis tot betaling van het surplus van een factuurbedrag voortvloeiend uit de toepassing van een gedifferentieerd tarief. ${ }^{86}$

De artikelen 2 en 3 WBM, de Belgische equivalenten van de artikelen 8I en 82 EG worden geacht van openbare orde te zijn. ${ }^{87}$ Overeenkomsten waarvan het voorwerp of de oorzaak in strijd is met deze bepalingen zijn absoluut nietig.

\subsubsection{Schadevergoeding}

Het Verdrag van Rome bevat geen bepaling met betrekking tot vorderingen tot schadevergoeding wegens schendingen van het mededingingsrecht. ${ }^{88}$ Dergelijke vorderingen konden enkel voor de nationale rechtbanken worden ingesteld indien zij volgens het toepasselijke nationale recht mogelijk waren. Eenmaal het Hof van Justitie in het Francovich-arrest het bestaan had erkend van een beginsel van gemeenschapsrecht inzake overheidsaansprakelijkheid, gingen er in de doctrine echter stemmen op voor de erkenning van een beginsel van gemeenschapsrecht inzake aansprakelijkheid van particulieren voor inbreuken op het mededingingsrecht. Aangezien de basis voor het beginsel van de aansprakelijkheid van de overheid voor schendingen van het gemeenschapsrecht gelegen is in het beginsel van het effet utile van het gemeenschapsrecht, was er volgens deze auteurs geen reden om een ander standpunt in te nemen ten aanzien van de aansprakelijkheid van particulieren voor zulke schendingen. ${ }^{89}$

In 1993 pleitte Advocaat-Generaal van Gerven in zijn conclusie in de zaak Banks voor de erkenning van een gemeenschapsrecht tot het verkrijgen van schadevergoeding voor schade veroorzaakt door een inbreuk op rechtstreeks afdwingbare regels van EU-mededingingsrecht. Het Hof van Justitie ging hier echter niet op in omdat het oordeelde dat in casu slechts de niet-rechtstreeks werkende artikelen $6_{5}$ en 66 EG van toepassing waren..$^{\circ}$

Sedert haar Witboek betreffende modernisering uit 1999 ijvert ook de Commissie actief voor een verhoogde privaatrechtelijke handhaving van de artikelen 8I en 82 EG. In dit Witboek wijst zij zowel op de bevoegdheid van nationale rechtbanken om schadevergoeding toe te kennen als om de uitvoering of niet-uitvoering van overeenkomsten te bevelen. ${ }^{91}$

86. Brussel 3 november 2005, www.ec.europa.eu/comm/competition/antitrust/actionsdamages/ files_white_paper/whitepaper_nl.pdf.

87. Brussel 23 november I995, Jaarboek Handelspraktijken en Mededinging (hierna: JHPM) I995, 645; Brussel 28 juni I995, JHPM I995, 576; H. Gilliams en L. Cornelis, o.c., TBM 2007, afl. 2, nr. 8, p. I3.

88. In deze zin ook A.P. Komninos, o.c., I62.

89. H. Smith, 'The Francovich Case: State Liability and the Individual's Right in Damages', ECLR I992, I32; M. Hoskins, 'Garden Cottage Revisited: The Availability of Damages in the National Courts for Breaches of the EEC Competition Rules', ECLR 1992, 259. Zie ook CA Jones, Private Enforcement of Antitrust Law in the EU, UK and USA, Oxford, I999, die een vurig pleidooi hield voor de private handhaving van het mededingingsrecht.

9o. HvJ EG I3 april 1994, H. J. Banks \& Co. Ltd/British Coal Corporation, zaak C-I28/92, Jur. I994, I-or209. Zie hierover ook A.P. Komninos, o.c., I66.

91. Zie Witboek, nr. 46 en 100. 
In 200 I zorgde het Hof van Justitie met het arrest Courage t. Crehan voor een doorbraak door het recht te erkennen van eenieder, inclusief een contractspartij, om vergoeding te vorderen van schade die hem is berokkend door een overeenkomst of een gedraging die de mededinging kan beperken of vervalsen ${ }^{22}$ als een recht dat deel uitmaakt van de communautaire rechtsorde. ${ }^{93}$ Het gemeenschapsrecht verzet zich volgens het Hof echter niet tegen een regel van nationaal recht, die een partij bij een overeenkomst die de mededinging kan beperken of vervalsen, het recht ontzegt zich ter verkrijging van schadevergoeding op zijn eigen onrechtmatig handelen te beroepen, wanneer vaststaat dat deze partij in aanzienlijke mate verantwoordelijk is voor de verstoring van de mededinging. ${ }^{94}$ In het motiverend gedeelte van het arrest Courage vermeldt het Hof dat de 'bij de nationale rechter ingediende schadevorderingen wezenlijk bijdragen tot de handhaving van een daadwerkelijke mededinging in de Gemeenschap'.95

Aldus erkent het Hof van Justitie de dubbele functie van dergelijke vorderingen: de compensatoire functie (vergoeding van de schadelijder) enerzijds en de handhavingsfunctie (voorkomen van mededingingsbeperkende gedragingen in de toekomst door afschrikking van potentiële inbreukplegers) anderzijds..$^{6}$

Vervolgens liet de Commissie een studie uitvoeren met betrekking tot de mogelijkheden en beperkingen die in het positieve recht van de verschillende rechtsstelsels van de EU bestaan om schadevergoeding te eisen wegens inbreuken op het mededingingsrecht. 97 De studie besloot dat dergelijke schadevorderingen in de EU totaal onderontwikkeld waren en dat er een verbazingwekkende diversiteit bestond in de wijze waarop deze vorderingen in de verschillende lidstaten worden benaderd..$^{8}$ Voortbouwend op deze studie publiceerde de Commissie een Groenboek waarin zij de volgende pijnpunten aan de orde stelde: (I) de toegang tot het bewijsmateriaal, (2) de schadevergoeding en de kosten van een rechtsvordering, (3) het passing-onverweer, 99 (4) de procesbevoegdheid van indirecte afnemers, (5) de interactie tussen

92. Nr. 26.

93. D. Beard en A. Jones, 'Co-contractors, Damages and Article 8I: The ECJ Finally Speaks', ECLR 2002, 25I e.v.; S. Drake, 'Scope of Courage and the principle of 'individual liability' for damages: further development of the principle of effective judicial protection by the Court of Justice', ELRev 2006, 84I-864; P.A. Komninos, 0.c., I67 en I70 e.v.; N. Reich, Understanding EU Law, Objectives, Principles and Methods of Community Law, Antwerpen, Intersentia, 2005, 333; C.H. Sieburgh, 'Het Europese gemeenschapsrecht en het Nederlandse buiten-contractuele aansprakelijkheidsrecht', in De invloed van het Europese recht op het Nederlandse privaatrecht, 521. Contra: A. Albors-Llorens, 'Courage t/Crehan: Judicial Activism or Consistent Approach?', CLJ 2002, 40; GeA 28 februari 2002, Atlantic Container Line AB e.a. t/Commission, zaak T-395/94, Jur. 2002, II-875, nr. 4I4.

94. Nr. 36 .

95. Nr. 27.

96. HvJ EG I3 juli 2006, Manfredi, Gevoegde zaken C-295/04 tot C-298/04, Jur. 2006, I-o66I9.

97. Ashurst, Study on the conditions of claims for damages in case of claims for damages of EC Competition rules. Comparative report, www.ec.europa.eu/comm/competition/antitrust/actionsdamages/comparative_report_clean_en.pdf.

98. Ashurst study, I.

99. D.i. het verweer dat de beweerde schadelijder de door hem beweerde schade heeft doorberekend aan zijn afnemers, en dus geen schade heeft geleden. 
de handhaving door mededingingsautoriteiten en door nationale rechters. Voor ieder van deze pijnpunten formuleerde de Commissie een aantal opties om tot een meer efficiënt systeem van schadevorderingen wegens schendingen van het mededingingsrecht te komen.

Hierna was het terug aan het Hof van Justitie. In het arrest Manfredi dd. I3 juli 2006 heeft het Hof van Justitie de principes vervat in het arrest Courage bevestigd en verder uitgewerkt. Het Hof van Justitie oordeelde dat 'Artikel 8I EG (...) aldus (moet) worden uitgelegd dat eenieder (...) indien er een causaal verband bestaat tussen (de schending van het mededingingsrecht) en de schade, schadevergoeding kan vorderen'. Bij gebreke van communautaire regelgeving ter zake is het, volgens het Hof van Justitie wel een aangelegenheid van de interne rechtsorde van elke lidstaat om met inachtneming van het gelijkwaardigheids- en doeltreffendheidsbeginsel de regels vast te stellen voor de uitoefening van dit recht, met inbegrip van de regels voor de toepassing van het begrip 'causaal verband' en om de bevoegde rechterlijke instanties, de toepasselijke procedureregels, verjaringstermijnen en de criteria voor de bepaling van de omvang van de schadevergoeding vast te stellen. Het Hof wijst erop dat, indien in het kader van vergelijkbare nationale vorderingen bijzondere vergoedingen, zoals exemplaire of punitieve schadevergoeding, kunnen worden toegekend, deze vergoedingen op grond van het gelijkwaardigheidsbeginsel ook kunnen worden toegekend in het kader van gelijkaardige vorderingen wegens schending van het gemeenschapsrecht. Het gemeenschapsrecht belet de nationale rechter echter niet erop toe te zien dat de bescherming van de door de communautaire rechtsorde gewaarborgde rechten niet leidt tot ongerechtvaardigde verrijking van de rechthebbenden. Uit het doeltreffendheidsbeginsel volgt volgens het Hof bovendien dat de personen die schade hebben geleden niet alleen vergoeding moeten kunnen vorderen van de reële schade (damnum emergens), maar ook van gederfde winst (lucrum cessans), en van rente.

Op 20 oktober 2006 nam het Europees Economisch en Sociaal Comité een Opinie aan waarin het de inspanningen van de Commissie tot het vergemakkelijken van schadevergoedingsacties wegens schendingen van het mededingingsrecht positief beoordeelt en het opstellen op het niveau van de Gemeenschap van regels tot bevordering van dergelijke acties onderschrijft. ${ }^{100}$ In april 2007 ondersteunde ook het Europees Parlement de werkzaamheden van de Commissie ter zake en verzocht het de Commissie om een Witboek voor te bereiden met gedetailleerde voorstellen om het instellen van vorderingen tot schadevergoeding in antitrustzaken te vergemakkelijken. Gevolg gevend aan het verzoek van het Europees parlement ${ }^{\mathrm{IOI}}$ publiceerde de Commissie in april 2008, een Witboek inzake schadevergoedingsacties wegens schending van de communautaire mededingingsregels dat een aantal voorstellen bevat voor een wetgevend optreden strekkend tot het bevorderen van dergelijke acties. Terwijl de Commissie in eerdere documenten de handhavingsfunctie van het privaatrecht benadrukte, stelt zij in het Witboek de volledige compensatie (een

I0o. (INT 306), www.eescopinions.eesc.europa.eu/EESCopinionDocument.aspx?identifier=ces $\mid$ int $\mid$ int306|cesi349-2006_ac.doc\&language=EN.

IoI. ResolutieEuropeesParlement2006/2207(INI), www.europarl.europa.eu/oeil/file.jsp?id=5378362. 
civilist zou eerder spreken van integrale schadeloosstelling) van de benadeelden van inbreuken op de communautaire mededingingsregels als hoofddoelstelling voorop. Het handhaven van het mededingingsrecht en het afschrikken van toekomstige potentiële inbreukmakers worden slechts vermeld als zijnde een inherent gunstig effect van een beter schaderecht. ${ }^{102}$ De Commissie lijkt hiermee tegemoet te komen aan de kritiek die zij ontving op eerdere documenten, namelijk dat zij een oneigenlijk gebruik wenste te maken van het aansprakelijkheidsrecht dat traditioneel gericht is op schadevergoeding om een betere afdwinging van het mededingingsrecht te bewerkstelligen. ${ }^{103}$ De Commissie benadrukt ook dat de privaatrechtelijke handhaving een aanvulling vormt op, maar niet in de plaats treedt van de publieke handhaving en deze ook niet in het gedrang brengt. ${ }^{104}$ Hoewel dit ongebruikelijk is, riep de Commissie in het Witboek opnieuw op tot reacties hieromtrent. Op basis van deze reacties bereidde de Commissie een ontwerp van richtlijn voor. Op 2 oktober van dit jaar werd het ontwerp evenwel ingetrokken. Het is niet duidelijk wanneer en zelfs of het hernomen zal worden. ${ }^{105}$

Naar Belgisch recht is ter zake van schadevorderingen wegens mededingingsrechtelijke inbreuken een onderscheid te maken tussen de contractuele en de buitencontractuele aansprakelijkheid. Indien de schending van het mededingingsrecht tegelijkertijd een contractuele wanprestatie uitmaakt (bijv. indien een dominante onderneming misbruikt maakt van haar machtspositie door in strijd met een contractuele verplichting levering te weigeren) staan het slachtoffer de gewone contractuele remedies ter beschikking: exceptio non adimpleti contractus, uitvoering in natura, ontbinding, schadevergoeding. De primaire remedie is in feite de uitvoering in natura of, bij een wederkerige overeenkomst, de ontbinding. Schadevergoeding kan worden gevorderd ter aanvulling van de uitvoering in natura of ontbinding, of indien uitvoering in natura en eventueel ontbinding niet mogelijk zijn of rechtsmisbruik zouden uitmaken, in plaats van die remedies. Indien de schending van het mededingingsrecht tevens een contractuele wanprestatie uitmaakt, ligt het voor de hand de vordering primair op de contractuele wanprestatie te baseren; dat er tevens een schending van het mededingingsrecht is, zal wellicht in vele gevallen niet eens opgemerkt worden.

Indien de schending van het mededingingsrecht geen contractuele wanprestatie uitmaakt, dan kan een vordering tot schadevergoeding worden gebaseerd op de onrechtmatige daad, de buitencontractuele aansprakelijkheid. Dit zal ook het geval zijn indien de schending van het mededingingsrecht een culpa in contrahendo uitmaakt, bijv. een weigering om te contracteren als dusdanig of een weigering om te contracteren onder niet-discriminerende voorwaarden. Buitencontractuele aansprakelijkheid vereist een fout, een schade en een causaal verband. De vraag rijst of

I02. Witboek, 3 .

I03. J.S. Kortmann en C.R.A. Swaak, o.c., ECLR 2009, 34I-342.

I04. Witboek, 4 .

I05. www.globalcompetitionreview.com/news/article/I8946/en-pulls-draft-private-litigationdirective. 
een schending van het mededingingsrecht per se het objectief bestanddeel van een buitencontractuele fout uitmaakt. Bepaalde auteurs oordelen dat de artikelen 8I en 82 EG en 2 en 3 WBEM daartoe geen voldoende concreet gebod of verbod van een bepaalde handeling inhouden. De schending van deze regels zou daarom enkel een fout uitmaken in de zin van artikel $\mathrm{I}_{3} 82-\mathrm{I}_{3} 83 \mathrm{BW}$ indien een normaal en zorgvuldig persoon geplaatst in dezelfde omstandigheden er zich van bewust zou zijn geweest dat de betreffende handelingen verboden waren. Gelet op de mogelijkheid om de zorgvuldigheidsnorm te concretiseren aan de hand van externe omstandigheden zoals opleiding en professionele kwalificaties zouden schendingen begaan door personen of ondernemingen met een goede kennis van de marktstructuur eerder als fout worden aangemerkt dan schendingen begaan door personen en ondernemingen met een minder goede marktkennis. Het zou ook moeilijk zijn om te argumenteren dat praktijken waarvan het algemeen bekend is of zou moeten zijn dat ze verboden zijn door het mededingingsrecht, zoals praktijken die de beperking van de mededinging tot voorwerp hebben, geen fout uitmaken. Ten aanzien van praktijken die slechts tot gevolg hebben dat de mededinging wordt beperkt zou dit gemakkelijker zijn. Het zou volstaan aan te tonen dat van een normaal zorgvuldige sales manager of bestuurder in een bepaalde sector niet kan verwacht worden dat hij de betreffende gedraging als verboden zou hebben gekwalificeerd. ${ }^{\text {106 }}$ De vraag of een schending van een regel van objectief recht slechts dan volstaat als objectief bestanddeel van de fout zonder dat een verdere zorgvuldigheidstoetsing is vereist, wanneer die regel een voldoend bepaald gebod of verbod inhoudt, is naar Belgisch recht niet met zekerheid te beantwoorden. Vast staat dat zowel de rechtspraak (met inbegrip van het Hof van Cassatie) als de rechtsleer courant oordelen dat het objectief bestanddeel van de fout kan bestaan uit één van de volgende twee elementen: (I) de schending van een welbepaalde of specifieke regel of (2) de schending van de algemene zorgvuldigheidsplicht. Het is niet geheel zeker of men met de termen 'welbepaalde' of 'specifieke' regel werkelijk duidt op een vereiste van 'bepaaldheid' van de norm, dan wel of men ze enkel gebruikt om het onderscheid te maken met de algemene zorgvuldigheidsplicht. Het Hof van Cassatie heeft zich hierover nog niet uitdrukkelijk moeten uitspreken. De onvoldoende bepaaldheid van de geschonden regel wel werd opgeworpen door de verweerders in cassatie in het zogenoemde 'ontwateringsbelastingarrest'. In zijn conclusie verwierp Procureur-generaal Vélu dit bezwaar oordelend dat 'le contenu des obligations constitutionelles et légales est le plus souvent sufissamment déterminé que pourqu'on puisse les considérer comme des obligations de résultat' en dat zulks ook in de voorliggende zaak het geval was. Het Hof van Cassatie ging hier niet dieper op in maar oordeelde dat de administratieve overheid, behoudens onoverkomelijke dwaling of een andere grond van uitsluiting van aansprakelijkheid een fout begaat wanneer zij een reglement aanneemt of goedkeurt dat indruist tegen grondwettelijke of wettelijke regels die haar een bepaald doen of nalaten opleggen. ${ }^{107}$ In andere zaken oordeelde het Hof van

Io6. H. Gilliams en L. Cornelis, o.c., TBM 2007, afl. 2, nr. 23 e.v., p. I7 e.v.

I07. Cass. I3 mei I982, Arr.Cass. I982, II34, Pas. I982, I, I056, met concl. A-G J. Velu. 
cassatie echter dat de welbewuste inbreuk op een norm een fout uitmaakt zonder te refereren aan de bepaaldheid van de norm. ${ }^{\text {108 }}$

Als de schending van een regel van objectief recht volstaat om het objectief bestanddeel van de fout uit te maken, dan kan een kwalificatie als fout slechts ontweken worden indien het subjectief bestanddeel van de fout, nl. de schuldbekwaamheid en/of toerekenbaarheid ontbreekt (zie hiervoor 2.2).

\subsection{Handelspraktijkenwet: handhaving van eerlijke concurrentie en consumentenrechten}

\subsubsection{Algemeen}

De wet op de handelspraktijken en de voorlichting en bescherming van de consument (WHPC) dient een dubbel doel. Enerzijds beschermt zij de eerlijkheid in de mededinging en in de handelsrelaties, anderzijds beschermt zij de consument en ziet zij erop toe dat hij voldoende informatie krijgt. De regels van de WHPC kunnen worden ingediend in zes categorieën van regels: (I) regels betreffende de aanduiding van productinformatie, (2) regels van verbintenisrechtelijke aard (informatieplichten, onrechtmatige bedingen, verplicht af te leveren documenten, stilzwijgende verlenging van dienstenovereenkomsten en enige andere regels betreffende de totstandkoming en uitvoering van overeenkomsten), (3) regels betreffende bijzondere gereglementeerde handelspraktijken (verkoop met verlies, uitverkopen, verkoop op afstand, verkoop buiten de onderneming, ...), (4) betreffende reclame en oneerlijke handelspraktijken, (5) betreffende consumentenakkoorden en (6) sancties.

De WHPC combineert burgerlijke, strafrechtelijke en administratieve rechtshandhavingsmechanismen. De burgerlijke handhaving van het recht inzake oneerlijke concurrentie gaat het verste terug in de tijd. Oorspronkelijk werd oneerlijke concurrentie immers bestreden op grond van artikel $1_{3} 82 \mathrm{BW}$. Het gebruik van deze rechtsgrond had echter een aantal nadelen: voor een veroordeling moest schade bewezen worden, voor iedere inbreuk moest een nieuwe procedure worden gevoerd, de gewone procedure duurde te lang en de procedure in kort geding kon slechts gebruikt worden in spoedeisende gevallen en leidde niet tot een beslissing ten gronde. Om hieraan te remediëren werd bij KB nr. 55 van 23 december 1934 een bijzondere regeling ingevoerd 'tot bescherming van de voortbrengers, handelaars en verbruikers tegen zekere handelswijzen strekkende tot het verdraaien van de normale voorwaarden der mededinging'. De belangrijkste innovatie van het $\mathrm{KB}$ bestond in de invoering van een bijzonder burgerrechtelijk handhavingsmechanisme: de vordering tot staken, die werd behandeld zoals in kort geding en kon worden toegewezen zonder dat schade bewezen moest worden. Overtreding van een definitieve uitspraak waarbij een bevel tot staken werd opgelegd was strafbaar. Ook tal van bijzondere handelspraktijken

I08. Cass. Io april 1970, Pas. I970, I, 682; Cass. 22 september I988, Pas. I98, I, 83; Cass. 3 oktober I994, Pas. I994, I, 788; T. Léonard, Conflits entre droits subjectifs, libertés civiles et intérêts légitimes, Brussel, Larcier, 2005, 325. 
werden strafbaar gesteld (onder andere verkoop met premie en openbare verkopen met miskenning van de terzake geldende voorschriften). Voor de overtreding van de eerlijke handelspraktijken tussen concurrenten werd de strafrechtelijke sanctionering evenwel gestadig afgebouwd door de wet op de handelspraktijken van (WHP) I97I en de WHPC van I99I. De strafrechtelijke sanctionering van overtredingen van de eerlijke handelspraktijken ten nadele van consumenten bleef wel overeind. ${ }^{\text {Iog }}$ Bij de meest recente wijzigingen aan de WHPC werden de strafrechtelijke sancties zelfs nog aangevuld. De wetgever beoogde hiermee een ontradend effect te bereiken evenals een verminderd risico op herhaling. De wetgever lijkt hierbij niet in de eerste plaats te rekenen op effectieve strafrechtelijke sanctionering door de strafrechtsmachten, maar veeleer op administratiefrechtelijke sanctionering. De WHPC voorziet immers in een specifieke administratieve procedure die ambtenaren in de mogelijkheid stelt om, op inzage van pv's die een inbreuk vaststellen op strafrechtelijk gesanctioneerde bepalingen van de WHPC, een som voor te stellen die de strafvordering doet vervallen (art. II3-II5 WHPC). ${ }^{\text {IIo }}$

De aanvankelijke depenalisatie van de overtredingen van de eerlijke handelsgebruiken tussen concurrenten was ingegeven door de wens om deze overtredingen uit de strafrechtelijke sfeer te halen en door het toegenomen vertrouwen in de vordering tot staken. Het behoud van de strafrechtelijke sanctionering van overtredingen jegens consumenten was wellicht ingegeven door het feit dat deze overtredingen gezien de ongelijkheid tussen de partijen als zwaarwichtiger werd aangevoeld en misschien ook om een bijkomende instantie, het parket, te laten instaan voor de handhaving ter compensatie van het feit dat consumenten minder snel naar de rechter zullen stappen dan concurrenten.

\subsubsection{Vordering tot staken}

Het rechtshandhavingmechanisme dat het meest typerend is voor de WHPC is de vordering tot staken. Op grond van artikel 95 lid I WHPC kan de voorzitter van de rechtbank van koophandel namelijk het bestaan vaststellen en de staking bevelen van een zelfs onder het strafrecht vallende daad die een inbreuk uitmaakt op de bepalingen van de WHPC en van een aantal andere door de artikelen 96 en 97 WHPC vermelde gedragingen. Verboden reclame tussen verkopers en oneerlijke handelspraktijken jegens consumenten kunnen zelfs reeds met een stakingsvordering worden aangevochten wanneer zij nog niet onder het publiek zijn gebracht of begonnen, maar de publicatie of invoering op het punt staat te gebeuren (artikel 95 lid 2).

De vordering tot staken gegrond op artikel 95 kan worden ingesteld op verzoek van de belanghebbenden (concurrent of consument), de minister (of de

I09. J. Stuyck, Handels- en economisch recht, II, Mededingingsrecht, Kartelrecht, in Beginselen van Belgisch Privaatrecht, Gent, Story-scientia, 2004, nr. I-5, p. I-5.

IIo. Memorie van Toelichting, Parl. St. Kamer 2006-07, DOC 5I 2983/0oI, 40-4I. Zie hierover nader E. Terryn, 'Misleidende en vergelijkende praktijken na de omzetting van de richtlijn oneerlijke handelspraktijken' in G. Straetmans, J. Stuyck en E. Terryn (eds.), De wet handelspraktijken anno 2008, Mechelen, Kluwer, 2008, nr. 69, p. 84-86. 
Directeur-generaal van de Algemene Directie Controle en Bemiddeling van de Federale Overheidsdienst Economie, K.M.O., Middenstand \& Energie), ${ }^{\mathrm{III}}$ een beroeps- of interprofessionele vereniging met rechtspersoonlijkheid, een vereniging ter verdediging van de consumentenbelangen die rechtspersoonlijkheid bezit en voor zover zij in de Raad voor het Verbruik vertegenwoordigd is of door de minister van Economische Zaken erkend is. ${ }^{\mathrm{II} 2}$ De wet bepaalt uitdrukkelijk dat de hiervoor genoemde verenigingen en groepen in afwijking van de artikelen 17 en 18 Ger. W. in rechte kunnen optreden voor de verdediging van hun statutair omschreven collectieve belangen (art. 98 § I lid I en 2 WHPC). Voor bepaalde specifieke stakingsvorderingen gelden bijzondere regels. ${ }^{\mathrm{II}}{ }^{\mathrm{W}}$

De vordering wordt ingesteld tegen degene die de regel overtreedt. Een vordering tot staken van het gebruik van onrechtmatige bedingen in de zin van artikel 33 WHPC kan afzonderlijk of gezamenlijk, worden ingesteld tegen verscheidene verkopers van dezelfde economische sector of hun verenigingen die gebruik maken dan wel het gebruik aanbevelen van dezelfde of van soortgelijke algemene contractuele bedingen. Als de inbreuk reclame betreft, geldt een getrapt systeem. De vordering kan in de regel alleen worden ingesteld tegen de adverteerder. Indien deze evenwel geen woonplaats in België heeft en geen verantwoordelijke persoon in België heeft aangewezen, dan kan de vordering eveneens worden ingesteld tegen de uitgever, respectievelijk tegen de drukker of maker en de verdeler alsmede elke persoon die er bewust toe bijdraagt dat de reclame uitwerking heeft (art. 97bis WHPC).

De vordering wordt ingesteld en behandeld zoals in kort geding (art. Ioo lid I WHPC).

De Voorzitter kan als bijkomende sanctie de aanplakking en/of publicatie van zijn vonnis of een samenvatting daarvan op kosten van de overtreder bevelen indien dit ertoe kan bijdragen dat de gewraakte daad of de uitwerking ervan ophouden (art. 99 WHPC).

Aan een stakingsbevel kan tevens een dwangsom worden gekoppeld. ${ }^{\mathrm{II}} 4$

\subsubsection{Nietigheid}

De bepalingen van de WHPC zijn overwegend van dwingend recht, soms zelfs van openbare orde, zodat ermee strijdige clausules relatief respectievelijk absoluut nietig zijn. Voor bepaalde door de artikelen 3 I en 32 WHPC omschreven onrechtmatige bedingen wordt de nietigheidssanctie uitdrukkelijk door artikel 33 WHPC verwoord. Hoewel kan worden aangenomen dat het hier een relatieve nietigheid betreft, vermits de betreffende bepalingen strekken tot bescherming van private belangen, moet sedert de arresten Océano Grupo, Cofidis, Mostaza Claro en Pannon worden

\footnotetext{
III. Tenzij het verzoek betrekking heeft op een met de eerlijke handelspraktijken strijdige daad, waardoor een verkoper de beroepsbelangen van één of meer andere verkopers schaadt of kan schaden (art. 98 § I, $2^{\circ}$ jo. 94/3 WHPC).

II2. Zelfde opmerking als in voorgaande voetnoot.

II3. Zie art. 98 WHPC.

II4. I. Demuynck, 'Rechtshandhaving door de stakingsrechter', RW 200I-02, nr. 27, p. I243. Zie bijv. Voorz. Kh. Gent 3 november 2003, JHPM 2003, 8II.
} 
aangenomen dat de rechter het beding ambtshalve dient te toetsen en het buiten toepassing dient te laten tenzij de consument zich daartegen verzet. ${ }^{\text {II5 }}$

\subsubsection{Met nietigheid verwante burgerlijke sancties}

Op grond van artikel $76 \mathrm{WHPC}$ is het 'verboden iemand, zonder dat hij hierom eerst heeft verzocht, enig produkt toe te zenden met het verzoek dit tegen betaling van zijn prijs te verwerven of het anders, zelfs kosteloos, aan de afzender terug te zenden. Het is eveneens verboden iemand, zonder dat hij hierom eerst heeft verzocht, enige dienst te verlenen met het verzoek die dienst, tegen betaling van zijn prijs, te aanvaarden'. ${ }^{\text {II6 }}$ Ingeval van overtreding van dit verbod mag de consument de toegezonden goederen behouden zonder tot enige betaling verplicht te zijn, onverminderd zijn recht om een beroep te doen op de regels van het burgerlijk recht of op de overige bepalingen van de WHPC. In geen geval is de geadresseerde verplicht de verleende dienst of het toegezonden product te betalen noch het product terug te zenden, zelfs niet indien een vermoeden werd geopperd dat men de dienst of de aankoop van het product stilzwijgend had aanvaard.

Naar aanleiding van de meest recente wijziging van de WHPC, bij wet van 5 juni 2007, werd voor schendingen van het verbod op het gebruik van oneerlijke handelspraktijken een analoge burgerlijke sanctie ingevoerd. Artikel 94/I4 § 2, lid 2 WHPC bepaalt namelijk dat de consument die het slachtoffer is geworden van bepaalde ernstige oneerlijke handelspraktijken, zoals het beweren dat een product het winnen bij kansspelen kan vergemakkelijken (art. 94/8, I5 $5^{\circ} \mathrm{WHPC}$ ), het bedrieglijk beweren dat een product of dienst ziekten, functiestoornissen of misvormingen kan genezen (art. 94/8, $16^{\circ} \mathrm{WHPC}$ ) of het wekken van de indruk dat de consument het pand niet mag verlaten vooraleer de overeenkomst is opgesteld (94/II, I ${ }^{\circ} \mathrm{WHPC}$ ), de terugbetaling van de betaalde sommen kan eisen binnen een redelijke termijn vanaf het moment dat hij kennis had of hoorde te hebben van het bestaan ervan, zonder dat hij verplicht is tot teruggave van het reeds geleverde product of de reeds geleverde dienst. ${ }^{\text {I7 }}$ Indien de voorwaarden voor de toepassing van deze bepaling zijn vervuld, dan dient de rechter de eis van de consument toe te wijzen. Hij beschikt ter zake niet over enige appreciatievrijheid. Wanneer de consument slachtoffer is geworden van andere oneerlijke handelspraktijken, dan kan de rechter, indien hij dit passend acht, op grond van artikel 94/I4 § 2 lid 3 WHPC eveneens de terugbetaling

II5. HvJ EG 27 juni 200o, Océano Grupo, Gevoegde zaken C-240/98 tot C-244/98, Jur. 200o, I-494I; HvJ EG 2I november 2002, Cofidis, zaak C-473/00, Jur. I-I0875; HvJ EG 26 oktober 2006, zaak C-I68/05, Jur. 2006, I-I042I; HvJ EG 4 juni 2009, Pannon, Mostaza Claro zaak C-243/o8, www.curia.eu.

II6. De minister kan van deze verbodsbepalingen afwijkingen toestaan voor aanbiedingen met een liefdadig doel. In dat geval moet het vergunningsnummer en de volgende vermelding 'De geadresseerde heeft geen enkele verplichting, noch tot betaling, noch tot terugzending' leesbaar, goed zichtbaar en ondubbelzinnig vermeld zijn op de documenten die op het aanbod betrekking hebben, art. 76 lid 3 WHPC.

II7. Dit geldt ook voor consumenten die het slachtoffer worden van de handelspraktijken bedoeld in art. $98 / 8, \mathrm{I}^{\circ}$ en $94 / \mathrm{II}, 2^{\circ}$ en $7^{\circ} \mathrm{WHPC}$. 
bevelen van reeds door de consument bepaalde sommen, zonder de consument tot teruggave van het reeds geleverde product of de reeds geleverde dienst te verplichten. Hier beschikt de rechter dus wel over appreciatievrijheid.

Uit de parlementaire voorbereiding blijkt dat de wetgever met de invoering van deze sanctie een compensatoir, maar ook een ontradend doel voor ogen had. '(D)e enkele nietigverklaring van het contract, zijn aanpassing of een herziening van de prijs' vormen volgens de Memorie van Toelichting 'geen schadeloosstelling van de consument evenmin als een echte sanctie voor de verkoper. De mogelijkheid om het geleverde goed of de geleverde dienst te behouden heeft derhalve tot doel het concrete en snelle herstel van de schade toe te laten die de consument als slachtoffer van een oneerlijke handelspraktijk heeft geleden'. ${ }^{118}$ 'Een dergelijke burgerlijke sanctie wil' aldus de Memorie van Toelichting 'vooral ontradend zijn' en tegemoet komen aan de eis van artikel I3 van de richtlijn oneerlijke handelspraktijken dat de lidstaten verplicht sancties vast te stellen die doeltreffend, evenredig en afschrikwekkend zijn'. ${ }^{\text {I9 }}$ Deze sanctie kan niet gevorderd worden voor de stakingsrechter, enkel voor de gewone rechter.

\subsubsection{Interpretatie ten voordele van de consument}

Artikel 3I $\$ 4$ WHPC bepaalt dat '[i]ndien alle of bepaalde bedingen van de overeenkomst schriftelijk zijn, (...) ze duidelijk en begrijpelijk moeten zijn opgesteld. In geval van twijfel over de betekenis van een beding, prevaleert de voor de consument gunstigste interpretatie. Deze uitleggingsregel is niet van toepassing in het kader van vordering tot staken bepaald in artikel 95'. De interpretatie ten voordele van de consument fungeert hier als sanctie op de onduidelijke redactie van een beding.

\subsubsection{Herroepingsrecht}

Ook de verlenging van het herroepingsrecht die wordt toegekend aan de consument indien de handelaar nalaat bepaalde precontractuele informatie te verstrekken bij overeenkomsten op afstand (art. 80 § 2 WHP) kan worden beschouwd als een private sanctie.

\subsubsection{Omkering van de bewijslast}

Wanneer een vordering tot staken wordt ingesteld door de bevoegde minister dan ligt de bewijslast omtrent de juistheid van de gegevens vervat in een handelspraktijk of reclameboodschap bij de adverteerder of verkoper. Wanneer de vordering wordt ingesteld door andere personen, dan kan de voorzitter van de rechtbank van koophandel wanneer hij zulks, rekening houdend met de gerechtvaardigde belangen

II8. MvT, Parl. St. Kamer 2006-07, 2983/0oI, 37.

II9. MvT, Parl. St. Kamer 2006-07, 2983/oor, 38. Zie hierover ook H. De Bauw, 'De algemene verbodsbepalingen in de relatie verkoper-consument' in G. Straetmans, J. Stuyck en E. Terryn (eds.), De wet handelspraktijken anno 2008, Mechelen, Kluwer, 2008, nr. 95 e.v., p. I40 e.v. 
van de partijen, passend acht de bewijslast eveneens verplaatsen naar de verkoper of adverteerder. Wanneer de verkoper of adverteerder het vereiste bewijs niet levert, dan kan de voorzitter van de rechtbank van koophandel de gegevens vervat in de handelspraktijk of reclameboodschap als onjuist beschouwen (art. 94/23 $\$ 2$ WHPC).

\subsubsection{Verhouding tussen het mededingingsrecht in strikte zin en de WHPC}

Artikel 94/3 WHPC verbiedt 'elke met de eerlijke handelsgebruiken strijdige daad, waardoor een verkoper de beroepsbelangen van één of meer andere verkopers schaadt of kan schaden'. Een inbreuk op de artikelen 8I en 82 EG en 2 en 3 WBEM is een door artikel 94/3 WHPC verboden daad. Om deze reden en omdat de stakingsvordering een snel en efficiënt resultaat oplevert, wordt de stakingsvordering vaak gehanteerd ter bestrijding van schendingen van de genoemde mededingingsbepalingen. Zo oordeelde de voorzitter van de rechtbank van koophandel van Brussel in de zaak Isopress bijvoorbeeld dat een persagentschap misbruik maakte van haar machtspositie door te weigeren om aan concurrerende persagentschappen informatie door te geven en hen aldus uit de markt te drijven. ${ }^{120}$

In de zaak Regie der Luchtwegen oordeelde het hof van beroep van Brussel dat de Regie der Luchtwegen die bij overheidsbeslissing instond voor de passagiersafhandeling voor derden door aan Belgavia exclusieve concessierechten toe te kennen voor de uitvoering van die taak in de luchthaven van Brussel-Nationaal en aldus derden uit de markt te houden, in strijd met artikel 82 EG (toen artikel 86) handelde. De toekenning van de exclusiviteitsrechten en de contractuele clausule die Belgavia verplichtte haar tarieven eerst ter goedkeuring voor te leggen aan de Regie werden strijdig bevonden met artikel 8I lid I EG (toen artikel 85). Het hof oordeelde dat de betreffende gedragingen tevens indruisten tegen de eerlijke handelsgebruiken en beval de staking ervan. ${ }^{\mathrm{I} 2 \mathrm{I}}$

In de zaak Belgacom/ITT Promedia oordeelde het hof van beroep van Brussel dat Belgacom misbruik maakte van haar machtspositie en overtredingen beging van de artikelen 3 WBEM en 86 EG door haar abonneegegevens slechts ter beschikking te stellen van een uitgever van telefoongidsen tegen een onbillijke, onredelijke en discriminerende prijs. Het hof oordeelde dat deze handelswijze de beroepsbelangen van ITT Promedia schaadde en beval de staking ervan. ${ }^{122}$

Over de vraag of mededingingsbeperkende handelingen die niet verboden zijn door de artikelen 8I en 82 EG en 2 en 3 WBEM op grond van de WHPC kunnen worden bestreden zijn de meningen verdeeld. Een eerste theorie verdedigt de absoluut beperkende werking of de reflexieve werking van de WBEM. Volgens deze theorie kan de WHPC op grond van het verbod van handelingen strijdig met de eerlijke han-

I20. Vz. Kh. Brussel I4 augustus I992, JHPM I992, 35I.

I2I. Brussel 7 december I995, JHPM I995, 676, noot F. Wijckmans.

I22. Brussel 9 juni I998, JHPM I998, 720. 
delsgebruiken geen gedragingen verbieden die zijn toegelaten door de WBEM. ${ }^{123}$ Een tweede theorie verdedigt de relatief beperkende werking van de WBEM op de WHPC en oordeelt dat enkel de gedragingen die verboden zijn door de WBEM óf deze die misbruik van recht inhouden oneerlijke handelspraktijken kunnen vormen in de zin van de WHPC. ${ }^{124}$ Een derde theorie verwerpt de beperkende werking van de WBEM en oordeelt dat de WBEM en de WHPC twee onafhankelijke wetten zijn en dat het begrip ‘eerlijke handelsgebruiken' uit de WHPC geenszins wordt beperkt door de WBEM. ${ }^{25}$

In een arrest van 7 januari 2000 overwoog het hof van Cassatie dat 'een gedraging van een onderneming, die de mededinging beperkt maar die toegelaten is uit het oogpunt van zowel het Europees mededingingsrecht als van de Belgische wet op de mededinging, niet op grond van de verplichting de eerlijke gebruiken in handelszaken na te leven kan worden verboden wanneer de beweerde miskenning van die eerlijke gebruiken er in wezen uitsluitend in bestaat de mededinging tussen de afnemers te beperken'. Het Hof wees er verder op dat de appelrechter in casu had geoordeeld 'dat verweersters geen misbruik hebben gemaakt van hun recht en aldus (uitsloot) dat op die laatste grond de miskenning van de eerlijke gebruiken in handelszaken zou kunnen worden bewezen'. ${ }^{126}$ Het Hof heeft niet uitdrukkelijk geoordeeld dat een gedraging die conform is met het mededingingsrecht, maar misbruik van recht inhoudt wel de eerlijke handelsgebruiken schendt, wanneer de beweerde miskenning van de eerlijke handelsgebruiken er in wezen uitsluitend in bestaat de mededinging tussen de afnemers te beperken. Het Hof heeft deze mogelijkheid echter ook niet uitgesloten. ${ }^{127}$ Evenmin heeft het de mogelijkheid uitgesloten dat een gedraging die de mededinging beperkt maar conform is met het mededingingsrecht, de eerlijke handelsgebruiken schendt wanneer de beweerde miskenning van de eerlijke handelsgebruiken er in wezen niet uitsluitend in bestaat de mededinging

I23. H. De Bauw, 'Onrechtmatige mededinging en vrije concurrentie. Over de wisselwerking tussen de Wet Handelspraktijken en de Wet Economische Mededinging', TBH I992, 682-699; L. Garzaniti en D. Vandermeersch, 'L'effet limitatif du droit de la concurrence sur le droit de la concurrence déloyale : état de la question', TBH I997, 4-I0; R. Van Den Bergh, 'Beroepsdeontologieën en eerlijke handelsgebruiken : geen synoniemen', RW I983-84, 545-568; R. Van den Bergh, 'Discriminatie van een onafhankelijke afnemer', JHPM I993, 463-468.

I24. J. Stuyck, I. Buelens en D. Counye, 'Verkoopsweigering en eerlijke handelsgebruiken', TBH I995, 80 .

I25. A. De Caluwé, 'La norme générale de conformité aux usages honnêtes est-elle principale ou résiduelle. Est-elle subordonnée à la loi du 5 août I99ı?', in C.U.P., Pratiques du Commerce, Liège, I997, I04 e.v.; D. Dessard en B. Francq, 'Application par les juridictions ordinaires' in P. De Vroede (ed.), Bescherming van de economische mededinging, die Keure, I993, nr. 30, p. I62; P. De Vroede, 'De stakingsrechter en de Belgische mededingingswet', RW I995-96, I37-I45.

I26. Cass. 7 januari 2000, Arr.Cass. 2000, 40 en JHPM 2000, 405. Voor toepassingen, zie : Voorz. Kh. Antwerpen 3 mei 200I, JHPM 2001, 902; Voorz. Kh. Antwerpen 20 februari 2003, JHPM 2003, I007; Voorz. Kh. Antwerpen 20 januari 2005, JHPM 2005, 963; Voorz. Kh. Tongeren 2I juni 2005, JHPM 2005, 979; Voorz. Kh. Antwerpen 6 april 2006, JHPM 2006, 553.

I27. J. Stuyck, 'L'effet réflexe du droit de la concurrence sur les normes de loyauté de la loi sur les pratiques de commerce', (noot onder Cass. 7 januari 2000), RCJB 200I, nr. I9, p. 262-263. 
tussen de afnemers te beperken, maar om een andere reden indruist tegen de eerlijke handelsgebruiken. ${ }^{\mathrm{I} 2} 8$

In een latere zaak, Iverlek, heeft het Hof van Cassatie geoordeeld dat 'een onderneming die geen dominante positie heeft op de betrokken markt door diensten te verkopen met verlies toch een inbreuk kan begaan op het verbod van oneerlijke handelspraktijken door onder omstandigheden diensten met verlies te verkopen; dat dit in het bijzonder het geval kan zijn wanneer de verkoop van diensten met verlies door een onderneming die geen dominante positie heeft, afgestemd is op de gedragingen van andere ondernemingen of van de overheid en een economisch ongeoorloofd doel nastreeft'. ${ }^{\text {I29 }}$

Dit arrest gaf aanleiding tot uiteenlopende interpretaties. Volgens bepaalde auteurs heeft het Hof van Cassatie met dit arrest de deur terug opengezet voor de theorie die de beperkende werking van het mededingingsrecht verwerpt en aanvaardt dat gedragingen die toegelaten zijn door het mededingingsrecht niettemin een schending kunnen inhouden van het verbod van oneerlijke handelsgebruiken. De ene auteur beoordeelt dit als een gunstige evolutie, ${ }^{130}$ de andere acht dit integendeel een onwenselijke evolutie. ${ }^{\text {3I }}$

Volgens een andere opvatting druist het standpunt van het Hof van Cassatie in het Iverlek arrest niet in tegen dat ingenomen in het arrest van 7 januari 2000, maar houdt het slechts een aanvulling en precisering daarvan in. ${ }^{132}$

Een auteur merkte terecht op dat elke handelspraktijk, zelfs indien zij in principe conform is aan de eerlijke handelsgebruiken, onrechtmatig wordt wanneer zij wordt verricht met de bedoeling om een ander te schaden. De auteur steunt deze opvatting op het adagium Fraus omnia corrumpit. ${ }^{133}$ Het uitoefenen van een recht met de bedoeling een ander te schaden makt ook rechtsmisbruik uit, een situatie waarin de sanctionering van een door het mededingingsrecht toegelaten mededingingsbeperkende gedraging ook door het cassatiearrest van 7 januari 2000 niet werd uitgesloten. ${ }^{134}$ Bovendien zou de verkoop met verlies ook geen geval zijn dat 'er in wezen uit-

I28. Vgl. J. Stuyck, o.c., RCJB 200I, nr. 26 e.v., p. 266 e.v.; D. Vandermeersch, 'Een door het mededingingsrecht toegelaten beperking van de mededinging strijdt op zich niet met de eerlijke handelspraktijken: De verkoopsweigering opnieuw bekeken', (noot onder Cass. 7 januari 2000), TBH 2000, 372-377.

I29. Cass. 25 oktober 200I, AJT 200I-02, 6I3, noot G. Ballon, Arr.Cass. 200I, I780, JHPM 200I, 393, noot H. De Bauw, RCJB 2004, afl. 2, I62, noot A. Puttemans en TBH 2002, afl. 5, 369, noot R. Steennot.

I30. A. De Streel, 'La liberté contractuelle à l'épreuve du droit de la concurrence' in Y. Poullet, P. Wéry en P. Wynants (eds.), Liber Amicorum Michel Coipel, Brussel, Kluwer, 2004, 275.

I3I. J. Stuyck, o.c., p. I63, nr. I97 en p. I76, noot I8I.

I32. A. Puttemans, 'La vente à perte de services comme acte de concurrence déloyale (ou: De 'l'effet limitatif' très limité du droit de la concurrence)', (noot onder Cass. 25 oktober 200I), RCJB 2004, 179-206.

I33. A. Puttemans, o.c., RCJB 2004, nr. 22, p. 202.

I34. Merk overigens op dat het verbod van bedrog/rechtsmisbruik ook in het gemeenschapsrecht is erkend, zie HvJ EG I2 mei I998, Kefalas e.a., zaak C-367/96, Jur. I998, I-I843; HvJ EG 2I februari 2006, Halifax, zaak C-255/02, Jur. 2006, I-I609. Zie hierover: W. Devroe, 'Impact van door het Europees Hof van Justitie ontwikkelde algemene beginselen op privaatrechtelijke verhoudingen' in De invloed van het Europese recht op het Nederlandse privaatrecht, nr. 58 e.v., p. I64 e.v. 
sluitend in bestaat de mededinging tussen de afnemers te beperken' en daarom niet onder de toepassing vallen van de regel van het cassatiearrest van 7 januari 2000. ${ }^{135}$

\subsection{Persoonlijkheidsrechten}

\subsubsection{Algemeen}

Het begrip 'persoonlijkheidsrechten' is in België geen wettelijk begrip. De rechtsleer definieert de persoonlijkheidsrechten als 'subjectieve rechten, die de titularis juridische zeggenschap verzekeren ten overstaan van derden over de bescherming en het gebruik van de intrinsieke bestanddelen of uitingen van de eigen persoonlijkheid'. ${ }^{13^{6}}$ De lijst van de erkende persoonlijkheidsrechten is dynamisch. Algemeen erkend zijn bijvoorbeeld wel het recht op leven, de fysieke integriteit, het recht op eer en goede naam, ... Sommige van deze rechten zoals het recht op eer en goede naam zijn ingeschreven in de (straf-)wet; andere zijn ontwikkeld door de rechtsleer en de rechtspraak. Sommige persoonlijkheidsrechten kunnen derhalve strafrechtelijk worden gehandhaafd; voor andere bestaat enkel de mogelijkheid van privaatrechtelijke handhaving.

\subsubsection{Schadevergoeding}

Over de invulling van de bewijslast in geval van schending van een persoonlijkheidsrecht, blijft betwisting bestaan. Volgens een eerste opvatting wijst de inbreuk op een subjectief recht niet automatisch op een fout in de zin van artikel 1382 B.W. L. Cornelis wijst erop dat subjectieve rechten steeds de weerspiegeling vormen van algemene en abstracte rechtsregels op een concrete rechtstoestand waarin het slachtoffer zich bevindt. Wanneer bijgevolg de inbreuk op een subjectief recht wordt gesanctioneerd aan de hand van artikel 1382 B.W., zal het slachtoffer de toepassingsvoorwaarden van deze aansprakelijkheidsregel moeten aantonen. Aldus behoort het slachtoffer fout, schade en causaal verband te bewijzen. ${ }^{\mathrm{I}}{ }^{37}$

Een tweede opvatting stelt terecht dat er wel ruimte is voor de reeds vermelde theorie van P. Leclerq. Uit de vaststelling dat een persoon beschikt over een subjectief recht, vloeit volgens $\mathrm{H}$. Bocken voort dat anderen de verplichting hebben om dat recht te respecteren. Er bestaan nu eenmaal rechten die meer bescherming verdienen dan andere, zodat zij ook op adequate wijze moeten worden beschermd. Wie inbreuk pleegt op andermans recht, overtreedt zo een gebodsnorm en handelt

I35. A. Puttemans, o.c., RCJB 2004, nr. I7, p. I97; R. Steennot, 'De verkoop met verlies en de eerlijke handelsgebruiken', (noot onder Cass. 25 oktober 200I), TBH 2002, nr. 8, p. 376.

I36. E. Guldix, De persoonlijkheidsrechten, de persoonlijke levenssfeer en het privéleven in hun onderling verband, proefschrift VUB, I986, nrs. I95-200; E. Guldix en A. Wylleman, 'De positie en de handhaving van persoonlijkheidsrechten in het Belgisch privaatrecht', TPR I999, nr. 3, p. I594.

I37. L. Cornelis, Beginselen van het Belgisch buitencontractueel aansprakelijkheidsrecht, Antwerpen, Maklu, I989, I50. 
onrechtmatig. ${ }^{13^{8}} \mathrm{H}$. Bocken beschouwt de inbreuk op recht als de overtreding van een rechtsplicht tot respect van andermans rechten of anders gezegd, als de schending van een norm die een bepaald gedrag verbiedt. De fout staat aldus vast door het bewijs van de rechtsinbreuk. Wel zal het slachtoffer nog zijn schade en het causaal verband moeten bewijzen. ${ }^{\text {I39 }}$

Volgens een derde opvatting moet de bescherming van de persoonlijkheidsrechten volledig losgekoppeld worden van artikel $1_{3} 82$ BW. E. Guldix heeft in haar proefschrift verdedigd dat aan de persoonlijkheidsrechten een eigen beschermende rechtsvordering verbonden moet zijn die, ingeval van rechtsinbreuk, aanleiding geeft tot een afzonderlijke handhavingsregeling voor een onafhankelijke rechter. Op deze wijze zou de fout niet moeten worden bewezen, maar evenmin de schade en het oorzakelijk verband. De rechter zou dan de krenking van het recht kunnen erkennen en bevestigen..$^{10}$ Een dergelijk afzonderlijk vorderingsrecht bestaat evenwel niet in ons recht ${ }^{\mathrm{I}}{ }^{\mathrm{I}}$ en is ons inziens ook niet noodzakelijk. Er wordt aan de slachtoffers reeds een voldoende rechtsbescherming geboden door de toepassing van artikel $\mathrm{I}_{3} 82 \mathrm{BW},{ }^{142}$ zeker nu kan worden aanvaard dat de inbreuk op een subjectief recht reeds een onrechtmatige daad kan vormen. Daarop is kritiek mogelijk in die zin dat het slachtoffer dan wel nog steeds schade en oorzakelijk verband moet kunnen bewijzen. Veelal zal het voor het slachtoffer dat de schending van een persoonlijkheidsrecht aanvoert, niettemin niet moeilijk zijn om zijn morele schade te bewijzen. Ook het bewijs van materiële schade is uiteraard toegelaten. ${ }^{143}$

Ook de rechtspraak is verdeeld, wat kan worden geilllustreerd met het recht op bescherming van de naam. De burgerlijke rechtbank te Gent oordeelde dat de loutere schending van het recht op naam, een fout oplevert. Het gebruik van de naam van een toptennisspeelster zonder haar toestemming leidt aldus tot de vaststelling van een fout. ${ }^{\mathrm{I} 44}$ Andere rechters vereisen een bijkomende zorgvuldigheidstoetsing. De voorzitter van het hof van beroep te Brussel oordeelde dat het gebruik van andermans naam enkel ingeval van verwarring een fout oplevert. Wanneer een bekend

138. H. Bocken, 'Nog iets over inbreuk op recht?', in Liber amicorum Walter Van Gerven, Mechelen, Kluwer, 2000, I88 e.v., die terecht opmerkt dat anders oordelen bovendien tot merkwaardige tegenstellingen tussen het aansprakelijkheidsrecht en zakenrecht zou leiden. Zakelijke rechten bezitten een sterk defensieve werking, die enkel door rechtsmisbruik of een wetsbepaling kan worden uitgeschakeld. Elke eigendomsaantasting kan worden bestreden met een zakelijke vordering. De analogie met de persoonlijkheidsrechten ligt voor de hand, zodat een minder verregaande bescherming niet wenselijk lijkt.

139. H. Bocken, o.c., in Liber amicorum van Walter van Gerven, I93. Ook in die zin: W. Van Gerven en S. Covemaeker, Verbintenissenrecht, Leuven, Acco, 2006, 366.

I40. E. Guldix, De persoonlijkheidsrechten, de persoonlijke levenssfeer en het privéleven in hun onderling verband, ro5 e.v. Voorts E. Guldix en A. Wylleman, 'De positie en de handhaving van persoonlijkheidsrechten in het Belgisch privaatrecht', TPR 2004, 44 e.v.

I4I. L. Cornelis, Beginselen van het Belgisch buitencontractueel aansprakelijkheidsrecht, I5O.

I42. Vgl. de bedenkingen van A. Van Oevelen, 'Schade en schadeloosstelling bij de schending van grondrechten door private personen', in K. Rimanque (ed.), De toepasselijkheid van grondrechten in private verhoudingen, Antwerpen, Kluwer, I982, 428; W. Van Gerven en S. Covemaeker, Verbintenissenrecht, 344-345.

I43. Zie A. Van Oevelen, o.c., in K. Rimarque (ed.), De toepasselijkheid van grondrechten in private verhoudingen, 428-429, die geen bezwaar heeft tegen het aanvaarden van een feitelijk vermoeden van morele schade ingeval van krenking van een subjectief recht.

I44. Rb. Gent I9 november 2003, AM 2004, 384. 
Vlaams acteur in een televisieprogramma een 'typetje' neerzet dat de naam draagt van een vroegere klasgenoot, vormt dat niet automatisch een fout. De rechter zal in concreto moeten oordelen of dit in strijd is met de algemene zorgvuldigheidsnorm. ${ }^{145}$

Inzake schadebegroting past de rechtspraak vooralsnog, althans in principe, op het aquilaanse model geschoeide regels toe. ${ }^{146}$ Hoewel morele schade in België van oudsher op gelijke voet met materiële schade als een vergoedbare schadepost wordt erkend, blijft de omvang van de toegekende schadevergoedingen bij schending van persoonlijkheidsrechten doorgaans beperkt. Over het algemeen kent men in een dergelijk geval, in het bijzonder bij schending van het recht op privacy slechts vergoedingen toe tussen 500 en I.250 euro. Bepaalde rechtspraak overweegt uitdrukkelijk dat de toekenning van een morele schadevergoeding geen manier mag zijn om de verantwoordelijke te straffen. ${ }^{\mathrm{I}}{ }^{7}$ Bepaalde rechtspraak kent, hoewel wordt overwogen dat degene die een persoonlijkheidsrecht schendt weliswaar niet mag worden gestraft, toch aanzienlijke schadevergoedingen toe omdat de morele schade van het slachtoffer op de meest volledige wijze moet worden vergoed. ${ }^{\mathrm{I} 48}$ Soms tracht de rechtspraak tevens een ruimere vergoeding toe te kennen door concrete (veelal slachtoffergebonden) elementen aan te duiden die een ruime begroting van de schade kunnen verantwoorden. ${ }^{149}$ Uitzonderlijk houdt de rechter openlijk rekening met de ernst van de fout van de dader. Zo hield de burgerlijke rechtbank te Brussel rekening met het feit dat het niet de eerste keer was dat een tijdschrift zich schuldig maakte aan een schending van het privéleven van derden ${ }^{150}$ en overwoog dezelfde rechtbank in een ander vonnis dat er bij de begroting van de morele schade rekening moest worden gehouden met de ernst van de fout van de dader. ${ }^{151}$

Schending van een persoonlijkheidsrecht kan ook aanleiding geven tot patrimoniale schade. Vooral bij bekende personen heeft hun afbeelding vermogenswaarde en houdt het niet-toegestaan en dus ook onbezoldigd gebruik van hun afbeelding een financieel verlies in. Deze financiële schade wordt in de rechtspraak echter zelden nauwkeurig begroot. Vaak wordt slechts één ex aequo et bono bepaald bedrag toegekend voor de patrimoniale en de morele schade. ${ }^{152}$

I45. Brussel Kort Ged. I2 januari i994, R.W. I994-95, 229.

I46. E. Guldix en A. Wylleman, o.c., TPR 1999, nr. 44, p. I653-I654.

I47. B. Weyts, o.c., RW 2005-06, nr. I3, p. I645 met verwijzing naar Rb. Gent 22 november I999, AM 2000, I48; Rb. Luik 2I september I999, AM 2000, I55, noot F. Jongen.

I48. Rb. Brussel 23 december I999, AM 2000 , I42.

I49. B. Weyts, o.c., RW 2005-06, nr. I5, p. I645. Zie bijv. Rb. Brussel 23 december I999, AM 2000, I38. Zie ook Rb. Antwerpen 12 juni 2008, AM 2008, 32I

I50. Rb. Brussel 30 april 2002, besproken door E. Montero en H. Jacquemin, 'La responsabilité civile des médias' in J.L. Fagnart (ed.), Responsabilités. Traité théorique et pratique, Brussel, Kluwer, 2003, 40 en B. Weyts, o.c., RW 2005-06, nr. 15, p. I646.

I5I. Rb. Brussel I6 november I999, AM 2000, I32.

I52. Brussel 4 oktober I989, RW I989-90, 65I, noot D. Voorhoof; Rb. Brussel I6 december I987, JT I988, 500; Rb. Brugge 3I januari I990, RW I99I-92, 234; E. Guldix en A. Wylleman, o.c., TPR I999, nr. 39 , p. 1650. 
Schadevergoeding hoeft echter niet steeds in geld te gebeuren, zij kan ook in natura geschieden en bijv. bestaan in de publicatie van het vonnis van veroordeling, ${ }^{153}$ of althans volgens een bepaalde opvatting het verbod van het (verder) verspreiden van publicaties die de schending een persoonlijkheidsrecht inhouden (zie hierna 2.5.4.).

In de rechtsleer wordt regelmatig een strengere handhaving door een vorm van punitive damages gesuggereerd. ${ }^{154}$

\subsubsection{Recht tot antwoord}

Wanneer een persoonlijkheidsrecht wordt geschonden door een publicatie in een periodiek tijdschrift, dan kan de titularis van dat persoonlijkheidsrecht krachtens artikel I van de wet van 23 juni i96I betreffende het recht van antwoord binnen drie maanden de kosteloze inlassing van een antwoord vorderen. De wetenschappelijke, artistieke of letterkundige kritiek levert echter slechts een recht van antwoord op indien dit ten doel heeft een zakelijk element recht te zetten of een aantasting van de eer af te weren.

Het antwoord mag niet meer bedragen dan duizend letters schrift of het dubbel van de ruimte ingenomen door de tekst die het recht tot antwoord rechtvaardigt. Wanneer het antwoord betrekking heeft op teksten die in verschillende opeenvolgende nummers zijn verschenen, mag het antwoord niet meer bedragen dan duizend letters schrift of het dubbel van de ruimte ingenomen door de langste van die teksten.

De vordering tot inlassing bevat de nauwkeurige opgaaf van de teksten, vermeldingen of aanhalingen waarop het antwoord betrekking heeft (art. 2).

De inlassing van een antwoord kan slechts geweigerd worden indien het niet onmiddellijk in verband staat met de bestreden tekst, beledigend is of in strijd met de wetten of de goede zeden, zonder noodzakelijkheid derden in de zaak betrekt of gesteld is in een andere taal dan die van het periodiek geschrift (art. 3).

Het antwoord moet in zijn geheel worden opgenomen zonder tussenvoeging, op dezelfde plaats en in dezelfde lettertekens als de tekst waarop het betrekking heeft in het eerste nummer dat verschijnt na afloop van een termijn van twee vrije dagen, de zondagen of feestdagen niet inbegrepen, en die ingaat op de dag waarop het antwoord ten kantore van het periodiek geschrift werd ingediend (art. 4).

Wanneer het antwoord niet of niet tijdig wordt gepubliceerd, staat strafrechtelijke vervolging open (art. 5).

Een vergelijkbaar recht op antwoord staat open voor de persoon of feitelijke vereniging wiens persoonlijkheidsrecht is geschonden door periodieke audiovisuele middelen. Het antwoord mag er dan wel slechts toe strekken één of meer onjuiste

I53. Rb. Brussel 7 november 2008, AM 2009, I77, noot; Rb. Mechelen 2 I juni 2005, AM 2005, 460; Rb. Brussel I6 december 1997, JLMB I998, 204; Rb. Brussel 22 november 1994, RGAR I995, nr. I2449; Rb. Brussel 22 november I994, RGAR I995, nr. I2450; E. Guldix en A. Wylleman, o.c., TPR I999, nr. 45 , p. 1655 .

I54. E. Guldix en A. Wylleman, o.c., TPR I999, nr. 44, p. I654-I655; B. Weyts, o.c., RW 2005-o6, nr. I5, p. 1646 . 
feiten die hem betreffen recht te zetten of om te antwoorden op één of meer feiten of verklaringen die van zodanige aard zijn dat zij de eer aantasten (art. 7 e.v. Wet 23 juni ig6r).

\subsubsection{Verbod of bevel}

Een 'echte' vordering tot staken van schendingen van persoonlijkheidsrechten is er niet. Wie een verbod wil laten uitspreken om een toekomstige schending van een persoonlijkheidsrecht te voorkomen of een voortdurende schending van een persoonlijkheidsrecht te doen ophouden, zal een beroep moeten doen op hetzij een vordering ten gronde op grond van buitencontractuele aansprakelijkheid of volgens sommigen een inherente vordering hetzij een gewone kortgedingprocedure.

Een vordering in kort geding vereist urgentie (art. 584 Ger.W.). Wanneer de verweerder op het punt staat een afbeelding of informatie uit de privésfeer openbaar te maken, wordt urgentie aanvaard. Wanneer de openbaarmaking reeds heeft plaatsgevonden, kan urgentie slechts worden aangenomen indien de beoogde maatregel de verdere verspreiding ervan nog kan tegengaan en de eisende partij niet al te zeer heeft gedraald om de maatregel te vragen. ${ }^{155}$

Een deel van de rechtsleer en de rechtspraak staat weigerachtig tegen het opleggen van een preventieve maatregelen die ertoe strekken of tot gevolg hebben dat bepaalde meningen om reden van hun inhoud niet kunnen worden geuit en verspreid. Dit zou resulteren in censuur. De handhaving van persoonlijkheidsrechten die in strijd komt met het recht op vrije meningsuiting zou daarom slechts a posteriori door een strafrechtelijke of civielrechtelijke veroordeling kunnen worden gerealiseerd. ${ }^{156}$

Andere rechtspraak en rechtsleer zijn van oordeel dat geen enkel recht, zelfs niet het recht op vrije meningsuiting zo absoluut kan zijn dat het buiten het bevoegdheidsdomein zou vallen van de kortgedingrechter die na afweging van conflicterende fundamentele rechten preventieve voorlopige maatregelen kan nemen ter bescherming van een ogenschijnlijk recht. ${ }^{157}$ Deze opvatting werd in 2006 bijgetreden door het Hof van Cassatie. ${ }^{58}$ De kortgedingrechter zal uiteraard wel slechts maatregelen met een voorlopig karakter kunnen treffen en hij zal moeten vermijden dat zijn beslissing naar de gevolgen toe van definitieve en onomkeerbare aard zou zijn zodat ze elke verdere beslissing ten gronde in de betreffende zaak haar

I55. Voorz. Antwerpen 6 november I998, JLMB I998, I750; Voorz. Rb. Tongeren 5 juni ig84, Limb. Rechtsl. I984, I43, noot J. Velaers; E. Guldix en A. Wylleman, o.c., TPR I999, nr. 34, p. I646.

I56. E. Brewaeys en D. Voorhoof, 'Het rechterlijk uitzendverbod van (een deel van) een TV-programma en de pers- en expressievrijheid', TBBR I99I, I99 e.v.; J. Ceuleers, 'Kan de rechter in kort geding preventief ingrijpen in een voorgenomen televisieuitzending?', (noot onder Voorz. Rb. Brussel I6 juni I993), RW I993-94, 620-62I; Voorz. Rb. Luik 29 januari I979, Jur. Liège I979, I87.

I57. Voorz. Rb. Brugge 6 november 2008, AM 2008, 496, noot; Voorz. Rb. Brussel 4 november 2008, AM 2008, 493; Voorz. Rb. Verviers 8 april 2008, AM 2008, 33I; Voorz. Rb. Brussel 29 februari 2008, AM 2008, 327.

I58. Cass. 2 juni 2006, AM 2006, afl. 4, 355, concl. P. De Koster, JLMB 2006, afl. 32, I403, noot F. Jongen, Pas. 2006, afl. 5-6, I302, concl. P. De Koster en Rev.trim.dr.fam. 2008, afl. I, 75. 
nut zou ontnemen. ${ }^{59} \mathrm{Om}$ het voorlopig karakter kracht bij te zetten wordt het publicatieverbod doorgaans voorwaardelijk geformuleerd en afhankelijk gemaakt van het inleiden van een procedure ten gronde binnen de maand na de beschikking in kort geding. ${ }^{160}$ Ook het Hof van Cassatie heeft erop gewezen dat in geval van een conflict tussen het recht op vrije meningsuiting en het recht op bescherming van het privé-leven een afweging moet worden gemaakt tussen deze rechten. ${ }^{16 \mathrm{I}}$

\subsubsection{Verklaring van recht}

Artikel I8 lid 2 Ger.W. maakt een rechtsvordering mogelijk tot het verkrijgen van een verklaring van recht indien zij ertoe strekt de schending van een ernstig bedreigd recht te voorkomen. Naast een ernstige bedreiging van een recht is vereist dat de gevorderde verklaring van recht van die aard is dat ze de eisende partij een concreet en bepaald nut kan bieden. Deze vordering is enkel zinvol indien de titularis van het recht verwacht dat de loutere rechterlijke vaststelling dat een bepaalde gedraging een inbreuk op een persoonlijkheidsrecht vormt, de wederpartij ervan zal weerhouden die inbreuk te plegen. Zij wordt weinig gebruikt. ${ }^{162}$

\subsection{Antidiscriminatie}

\subsubsection{Algemeen}

De discriminatieverboden in de Grondwet en de Internationale Verdragen buiten beschouwing gelaten, is de oudste Belgische antidiscriminatiewet de wet van 30 juli I98I tot bestraffing van bepaalde door racisme en xenofobie ingegeven daden. ${ }^{163}$ Zoals uit haar titel blijkt, opteerde deze wet voor een strafrechtelijke aanpak. Dat was ook het geval voor de wet van 7 mei 1999 op de gelijke behandeling van mannen en vrouwen ten aanzien van de arbeidsvoorwaarden, de toegang tot het arbeidsproces en de promotiekansen, de toegang tot een zelfstandig beroep en de aanvullende regelingen voor de sociale zekerheid. ${ }^{164}$ De strafrechtelijke aanpak bleek echter te leiden tot een rechtshandhavingstekort. Dit werd scherp in de verf gezet tijdens de parlementaire voorbereiding van de meer algemene discriminatiewet van 25 februari 2003. In een Nota betreffende de strijd tegen de discriminaties en betreffende het Centrum voor gelijkheid van kansen en voor racismebestrijding, aangenomen door de Ministerraad van 17 maart 2000 wordt erop gewezen dat '(b)epaalde praktische moeilijkheden (...) nog al te vaak de volle en noodzakelijke toepassing van de strafwet (verhinderen)'. Men denkt daarbij aan 'de moeilijkheden die ondervonden worden door de vreemdelingenbevolking om de initiële filters te doorbreken die de

I59. Brussel 26 oktober I989, TBBR I99I, 240; Voorz. Brussel I2 november I997, JLMB I998, 775.

I60. E. Guldix en A. Wylleman, 0.c., TPR I999, nr. 35, p. I647. Zie bijv. Voorz. Rb. Hasselt 30 januari I99I, Limb. Rechtsl. I997, I00; Voorz. Rb. Brussel I2 november I997, JLMB I998, 775.

I6I. Cass. I3 september I99I, Arr. Cass. I99I-92, 46 en RW I99I-92, 464.

I62. E. Guldix en A. Wylleman, o.c., TPR I999, nr. 3I, p. I644-I645.

I63. BS 8 augustus ig8r.

r64. BS r9 juni i999. 
politie en de rijkswacht soms vertegenwoordigen bij het registreren van klachten of het opstellen van processen-verbaal, de moeilijkheid om het bewijs aan te tonen van de racistische bedoeling van een reeks racistische daden, het gebrek aan doorzettingsvermogen dat men vindt bij sommige mensen die een klacht indienen en van wie de samenwerking vaak onmisbaar is, de terughoudendheid van sommige parketten, de quasi immuniteit die sommige racistische geschriften genieten met als enige reden dat ze gelijkgesteld werden met persmisdrijven'. ${ }^{165}$

Tussen I98I en I989, bleken I.266 klachten wegens racisme te zijn ingediend, waarvan er 987 zonder gevolg werden geklasseerd. Slechts drieënveertig dossiers gaven tijdens de betreffende periode aanleiding tot een gerechtelijke beslissing waarvan zestien veroordelingen, veertien vrijspraken en vier buitenvervolgingstellingen. In de loop van de laatste jaren voor de eeuwwisseling bleek het aantal gerechtelijke beslissingen met toepassing van de wet van 30 juli I98I weliswaar een sterke stijging te hebben gekend (alleen in de loop van 1998 werden elf gerechtelijke procedures afgerond!), maar toch achtte men het een feit dat te weinig veroordelingen, gesteund op de antiracismewet, werden uitgesproken in verhouding tot het aantal ingediende klachten. Ter remediëring van deze onwenselijke toestand werd onder meer voorgesteld burgerlijke sancties op te nemen in de Antiracismewet. ${ }^{\text {.66 }}$ De strafrechtelijke handhaving van het verbod van discriminatie tussen mannen en vrouwen met betrekking tot bepaalde beroeps- en sociale aangelegenheden, bleek nog minder efficiënt. ${ }^{167}$

In 2003 werd dan door een eerste wet van 20 januari, de bestaande strafwetgeving inzake antiracisme op een beperkt aantal punten versterkt door o.m. het opdracht geven tot discriminatie gelijk te stellen met discriminatie (art. I lid 2) en de straffen voor discriminatie jegens een persoon in de omstandigheden van artikel 2 bis van de wet ook te laten gelden voor discriminatie jegens een groep, een gemeenschap of de leden ervan. ${ }^{68}$ Een tweede wet van 25 februari 2003 voerde een meer algemeen verbod in tot discriminatie wegens het geslacht, de seksuele geaardheid, de burgerlijke staat, de geboorte, het fortuin, de leeftijd, het geloof of de levensbeschouwing, de huidige of toekomstige gezondheidstoestand, een handicap of een fysieke eigenschap. Dit discriminatieverbod werd in se evenwel niet strafrechtelijk, maar enkel burgerrechtelijk gehandhaafd. Wel werd het aanzetten en het openlijk zijn voornemen te kennen geven tot discriminatie evenals de discriminatie door bepaalde gezagsdragers strafbaar gesteld en werden strafverzwaringen ingevoerd voor bestaande misdrijven, voor het geval zij gepleegd worden uit haat gebaseerd op bepaalde door de wet vermelde discriminatiegronden (art. 7 tot I4). De belangrijk-

I65. Bijlage 3 bij het Verslag namens het adviescomité voor de gelijke kansen voor vrouwen en mannen uitgebracht door mevrouw Laloy bij het wetsvoorstel ter bestrijding van discriminatie en tot wijziging van de wet van 15 februari 1993 tot oprichting van een Centrum voor gelijkheid van kansen en voor racismebestrijding, Parl. St. Senaat, I999-2000, 2-12/3, 40.

I66. Ibidem, 40 e.v.

I67. Memorie van Toelichting bij het wetsontwerp van 26 oktober 2006 ter bestrijding van discriminatie tussen vrouwen en mannen, Parl. St. 2006-07, nr. 272I/oor, p. 25.

I68. Zie hierover nader D. De Prins, S. Sottiaux en J. Vrielink, Handboek discriminatierecht, Mechelen, Kluwer, 2005, nr. 743, p. 299-300. 
ste handhavingsmiddelen van de Antidiscriminatiewet waren van burgerrechtelijke aard: nietigheid van discriminerende bedingen, vordering tot staken, bijzondere bewijsregelen, bescherming van werknemers tegen represailleontslag. Bovendien konden, zoals dat overigens reeds vóór de Antidiscriminatiewet het geval was, bepaalde algemene leerstukken van het verbintenissenrecht worden aangewend om discriminatie te bestrijden. Zo makt een schending van een wettelijk gebod of verbod, zoals het grondwettelijke discriminatieverbod dat gedeeltelijk geconcretiseerd werd door de antidiscriminatiewetgeving, overeenkomstig het gemene buitencontractuele aansprakelijkheidsrecht een objectieve onrechtmatigheid uit, die mits de vereisten van schuldbekwaamheid en toerekenbaarheid evenals van schade en causaal verband vervuld zijn, aanleiding kon geven tot een verplichting tot schadevergoeding. Contracten met een discriminatoir voorwerp of een discriminatoire oorzaak zijn nietig op grond van de artikelen 6, II3I en II33 BW. In bepaalde omstandigheden kan een beroep worden gedaan op wilsgebreken, de verplichting tot uitvoering te goeder trouw, de verbindende kracht van het aanbod, ...

De Antidiscriminatiewet van 2003 was evenwel geen lang en gelukkig leven beschoren. Zij werd spoedig op een aantal punten vernietigd door het Arbitragehof (thans Grondwettelijk Hof genoemd) omdat zij zelf discriminerend werd bevonden en bleef ook niet vrij van kritiek vanwege de Europese Commissie op de wijze van omzetting van Richtlijn 2000/43/EG van de Raad van 29 juni 2000 houdende toepassing van het beginsel van gelijke behandeling van personen ongeacht ras of etnische afstamming. ${ }^{169}$ Bovendien werden in 2002 en 2004 op het niveau van de Europese Gemeenschap twee Richtlijnen aangenomen die een aanpassing van de Antidiscriminatiewet vereisten. ${ }^{170}$

Door drie wetten van Io mei 2007 werd de Belgische antidiscriminatiewetgeving dan ook hervormd. ${ }^{17 \mathrm{I}}$ De wet ter bestrijding van discriminatie is de meest algemene antidiscriminatiewet, die in zekere zin de Antidiscriminatiewet van 25 februari 2003 vervangt. De discriminatie tussen vrouwen en mannen werd uit deze algemene wet gelicht en ondergebracht in een afzonderlijke wet betreffende de discrimina-

I69. $\mathrm{Pb}$ L ig juli 2000, afl. I80, 22.

170. Richtlijn 2002/73/EG van het Europees Parlement en de Raad van 23 september 2002 tot wijziging van Richtlijn 76/207/EEG van de Raad betreffende de tenuitvoerlegging van het beginsel van gelijke behandeling van mannen en vrouwen ten aanzien van de toegang tot het arbeidsproces, de beroepsopleiding en de promotiekansen, en ten aanzien van de arbeidsvoorwaarden, $\mathrm{Pb} L 5$ oktober 2002, afl. 269, I5 en Richtlijn 2004/II3 EG van de Raad van I3 december 2004 houdende toepassing van het beginsel van gelijke behandeling van mannen en vrouwen bij de toegang tot en het aanbod van goederen en diensten, $\mathrm{Pb} \mathrm{L}$ 2I december 2004, afl. 373, 37.

I7I. Wet van Io mei 2007 ter bestrijding van bepaalde vormen van discriminatie, BS 30 mei 2007 (hierna : Antidiscriminatiewet); wet van ro mei 2007 tot wijziging van de wet van 30 juli I98I tot bestraffing van bepaalde door racisme of xenofobie ingegeven daden, BS 30 mei 2007 (hierna: Antiracismewet); wet van Io mei 2007 ter bestrijding van discriminatie tussen vrouwen en mannen, BS 30 mei 2007 (hierna: Genderwet). In feite is er nog een vierde wet van ro mei 2007 die het Gerechtelijk Wetboek aanpast aan de wetgeving ter bestrijding van discriminatie en tot bestrijding van door racisme of xenofobie ingegeven daden. 
tie tussen mannen en vrouwen. Een derde wet wijzigt de wet van 30 juni I98I tot bestraffing van bepaalde door racisme of xenofobie ingegeven daden. ${ }^{172}$

Centraal in zowel de Antidiscriminatie-, de Antiracisme- als de Genderwet staat een discriminatieverbod. ${ }^{173}$ De criteria op grond waarvan discriminatie verboden is door de Antidiscriminatiewet zijn: leeftijd, seksuele geaardheid, burgerlijke staat, geboorte, vermogen, geloof of levensbeschouwing, politieke overtuiging, taal, huidige of toekomstige gezondheidstoestand, een handicap, een fysieke of genetische eigenschap, sociale afkomst. ${ }^{174}$ De door de Antiracismewet beschermde criteria zijn: nationaliteit, een zogenaamd ras, huidskleur, afkomst of nationale of etnische afstamming. ${ }^{175}$ Het door de Genderwet beschermde criterium is uiteraard het geslacht.

Onder discriminatie verstaat men directe discriminatie, indirecte discriminatie en opdracht tot discriminatie. ${ }^{176}$ Directe discriminatie duidt op een direct onderscheid op grond van een beschermd criterium dat niet gerechtvaardigd kan worden op grond van de rechtvaardigingsgronden vermeld in de respectieve wetten. ${ }^{177}$ 'Direct onderscheid' wordt omschreven als 'de situatie die zich voordoet wanneer iemand ongunstiger wordt behandeld dan een ander in een vergelijkbare situatie wordt, is of zou worden behandeld op basis van één van de beschermde criteria'. ${ }^{78}$

Indirecte discriminatie duidt op een indirect onderscheid op grond van een beschermd criterium dat niet gerechtvaardigd kan worden op grond van de rechtvaardigingsgronden vermeld in de respectieve wetten. ${ }^{\text {I79 }}$ Indirect onderscheid wordt gedefinieerd als 'de situatie die zich voordoet wanneer een ogenschijnlijk neutrale bepaling, maatstaf of handelwijze personen gekenmerkt door een bepaald beschermd criterium, in vergelijking met andere personen bijzonder kan benadelen'. ${ }^{180}$

De opdracht tot discrimineren wordt omschreven als 'elke handelwijze die erin bestaat wie ook opdracht te geven een persoon, een groep, een gemeenschap of een van hun leden te discrimineren op grond van één van de beschermde criteria'. ${ }^{181}$

I72. De optie voor drie naast elkaar staande wetten is ingegeven door het feit dat het recht van de Europese Unie niet helemaal dezelfde regeling koppelt aan alle vormen van discriminatie, zodat het opstellen van één enkele wet die van toepassing zou zijn op alle vormen van discriminatie het gevaar zou inhouden dat niet alle regels van het Europees Gemeenschapsrecht correct zouden worden omgezet of dat een tekst zou worden opgesteld die zo complex zou zijn dat het voordeel van één enkele tekst verloren zou gaan, zie Verslag Commissie, I2.

173. De antidiscriminatiewetten hebben een zeer ruim toepassingsgebied, zie hierover de art. 5 Antidiscriminatiewet en de Antiracismewet en art. 6 Genderwet.

I74. Art. 4, $4^{\circ}$, Antidiscriminatiewet.

I75. Art. $4,4^{\circ}$, Antiracismewet.

176. Art. I2 Antiracismewet, art. I4 Antidiscriminatiewet en art. I9 Genderwet.

I77. Art. 4, $7^{\circ}$, Antiracismewet; art. 4, $7^{\circ}$, Antidiscriminatiewet ; Art. 5, 6º Genderwet. Zie hierover nader A. Van Oevelen en C. Cauffman, o.c. in Bijzondere overeenkomsten 2007-2008, XXXIVste postuniversitaire cyclus Willy Delva, Mechelen, Kluwer, 2008, 467 e.v.

I78. Art. 4, 60, Antiracismewet, art. 4, 6० Antidiscriminatiewet. Vgl. art. 5, $5^{\circ}$, Genderwet.

I79. Art. 4, $9^{\circ}$, Antiracismewet, art. 4, $9^{\circ}$, Antidiscriminatiewet en art. 5, $8^{\circ}$, Genderwet.

I80. Art. $4,8^{\circ}$, Antiracismewet, art. 4, $8^{\circ}$, Antidiscriminatiewet. Vgl. art. 5, $7^{\circ}$, Genderwet

I8I Art. $4, \mathrm{I}^{\circ}{ }^{\circ}$, Antiracismewet, art. $4, \mathrm{I} 3^{\circ}$, Antidiscriminatiewet. Vgl. art. 5, $12^{\circ}$ Genderwet. 
Binnen het toepassingsgebied van de algemene antidiscriminatiewet vormt ook het ontbreken van 'redelijke aanpassingen voor personen met een handicap' een verboden discriminatie. ${ }^{\mathrm{I} 82}$

Gezien de ervaring van de wetgever uitwees dat strafrechtelijke sancties ondoeltreffend waren, wat hij meer bepaald toeschrijft aan de onmogelijkheid van een omkering van de bewijslast in strafzaken, opteerde de wetgever bij de redactie van de nieuwe antidiscriminatiewetgeving, in de lijn van Antidiscriminatiewet van 2003, primair voor burgerrechtelijke sancties. Deze omvatten: de nietigheid van discriminatoire bepalingen, de bescherming tegen represailles binnen en buiten arbeidsverhoudingen, een forfaitaire schadevergoeding, een stakingsvordering en een omkering van de bewijslast. De strafrechtelijke bescherming blijft voor de criteria beschermd door de Genderwet en de Antidiscriminatiewet beperkt tot het aanzetten tot discriminerend gedrag, discriminatie door openbare ambtenaren en een strafverzwaring voor bepaalde misdrijven indien zij ingegeven zijn door verwerpelijke motieven en het zich niet voegen naar een stakingsbevel. Voor de racismewet wordt hieraan toegevoegd: het verspreiden van denkbeelden gegrond op rassuperioriteit of rassenhaat, de deelname aan organisaties die aanzetten tot discriminatie, discriminatie bij de toegang tot en het aanbod van goederen en diensten die publiekelijk beschikbaar zijn en in arbeidsbetrekkingen.

\subsubsection{Nietigheid}

Contractuele bedingen die in strijd zijn met de Antidiscriminatie-, de Antiracismeof de Genderwet of waarbij de partijen vooraf afzien van de bescherming van deze wetten, zijn nietig. ${ }^{183}$ De wet spreekt zich niet uit over de aard van de nietigheid. Er kan weinig twijfel over bestaan dat het om een absolute nietigheid gaat. Het discriminatieverbod vormt immers een fundamentele regel van ons rechtsbestel die, in de door het Hof van Cassatie gegeven omschrijving van een wet van openbare orde, een rechtsregel is die de essentiële belangen van de Staat of de gemeenschap raakt of die in het privaatrecht de juridische grondslagen vestigt waarop de morele orde van de maatschappij is gebaseerd. ${ }^{184}$

De wet beperkt de nietigheid tot het discriminerende beding. De wetgever wenst aldus de zwakkere partij te beschermen die niet noodzakelijk baat heeft bij de nietigheid van de volledige overeenkomst. ${ }^{185}$ Hiervoor vermelden wij reeds dat er in het arbeidsrecht precedenten zijn die de nietigheid beperken tot het discriminerende

I82. Art. $4, \mathrm{I}^{\circ}$, Antidiscriminatiewet.

I83. Art. I2 Antiracismewet; art. I5 Antidiscriminatiewet; art. 20 Genderwet.

I84. Zie de rechtspraak vermeld in voetnoot 18.

I85. In die zin m.b.t. de Antidiscriminatiewet van 2003: Parl. St. Senaat I999-2000, nr. 2-2I/I, p. 6; Parl. St. Senaat 200I-02, nr. 2-I2/I5, p. 9; I. Samoy en Y. Thiery, o.c., in Antidiscriminatiewet en contracten, p. Io, nr. I6; K. Vanderschot, 'De bestrijding van discriminatie in het gemeen contractenrecht', in Antidiscriminatiewet en contracten, p. 53, nr. 17. Vgl. P. Taelman, o.c., in De Wet Bestrijding Discriminatie in de praktijk, p. 206, nr. 7. 
deel van het beding, ${ }^{186}$ met als gevolg dat het slachtoffer van de discriminatie aanspraak kan maken op dezelfde voorwaarden als de groep ten aanzien van wie hij benadeeld werd, zelfs retroactief. ${ }^{187}$

\subsubsection{Schadevergoeding}

Het slachtoffer van een discriminatie kan een schadevergoeding vorderen met toepassing van de regels van het contractuele of buitencontractuele aansprakelijkheidsrecht.

Het slachtoffer heeft de keuze tussen het vorderen van de werkelijk geleden schade en het vorderen van een forfaitair door de wet bepaald bedrag. Kiest het slachtoffer voor de vergoeding van de werkelijke schade, dan moet het de omvang van de geleden schade bewijzen. ${ }^{\text {i }} 8$

Behoudens voor gevallen van discriminatie op het domein van het arbeidsrecht of de sociale zekerheid, bepalen de Antiracisme-, de Antidiscriminatie- en de Genderwet enkel een forfaitaire vergoeding voor morele schade. Deze is vastgesteld op 650 euro. Dat bedrag wordt verhoogd tot $\mathrm{I} .300$ euro indien de dader niet kan aantonen dat de betwiste ongunstige of nadelige behandeling ook op niet-discriminerende gronden getroffen zou zijn of op grond van andere omstandigheden, zoals de bijzondere ernst van de geleden morele schade. ${ }^{189}$

Deze nieuwe regeling strookt niet met de regel van het objectieve en integrale herstel, die het aansprakelijkheidsrecht in België beheerst. ${ }^{190}$ Normaliter mag de feitenrechter enkel rekening houden met de schade om de omvang van de schadevergoeding te bepalen. Andere elementen zijn niet van belang. ${ }^{191}$ De idee van een forfaitaire schadevergoeding is hier per definitie vreemd aan. In de parlementaire voorbereiding wordt aangegeven dat het slechts een schijnbare revolutie betreft omdat de evaluatie van morele schade altijd arbitrair is. ${ }^{192}$ Dit strookt niet volledig met de waarheid, nu de regel van het objectief herstel ook geldt bij de begroting van morele schade. Er kan evenwel niet worden ontkend dat de begroting van de morele schade veel moeilijker is dan die van de materiële schade. Om daaraan tegemoet te komen voorziet de Indicatieve Tabel in forfaitaire bedragen voor de vergoeding van de morele schade. Niettemin is dat slechts een leidraad voor de rechter, zodat hij daar nooit door gebonden is.

I86. Cass. 27 januari I994, Soc. Kron. I994, 75, noot J. Jacqmain; I. Samoy en Y. Thiery, o.c., in Antidiscriminatiewet en contracten, p. Io, nr. I6; I. Verhelst en I. De Wilde, o.c., NjW 2003, p. 448, nr. 32.

I87. Zie 2.I.5.

I88. Art. I6, § I, Antiracismewet; art. I8, § I, Antidiscriminatiewet; art. 23, § I, Genderwet.

I89. Art. I6, § 2, I, Antiracismewet; art. I8, § 2, I, Antidiscriminatiewet en art. 23, § 2, I, Genderwet.

I90. Vgl. de bedenkingen van J.F. Germain en C. Eyben, 'Les sanctions civiles. La nullité et les dommages et intérêts forfaitaires', in C. Bayart, S. Sottiaux en S. Van Drooghenbroeck (eds.), De nieuwe federale antidiscriminatiewetten, Brugge, die Keure, 2008, 349 e.v.

I9I. D. Simoens, Buitencontractuele aansprakelijkheid, deel II Schade en schadeloosstelling, in Beginselen van Belgisch privaatrecht, Gent, Story-scientia, I999, 2 I e.v.

192. Memorie van Toelichting, Parl.St.Kamer 2006-07, nr. 2722/00I, p. 27. 


\subsubsection{Vordering tot staken}

Op verzoek van het slachtoffer van de discriminatie, van het openbaar ministerie of van een door de wet vermelde instelling kan de voorzitter van de rechtbank van eerste aanleg het bestaan vaststellen van een zelfs onder het strafrecht vallende overtreding van de Antidiscriminatie-, Antiracisme- of Genderwet en kan hij de staking ervan bevelen. ${ }^{193}$ Op verzoek van het slachtoffer kan de voorzitter ook de door de wet bepaalde forfaitaire schadevergoeding aan het slachtoffer toekennen. ${ }^{\text {I94 Indien }}$ zulks ertoe kan bijdragen dat de gewraakte daad of de uitwerking ervan ophouden, kan de voorzitter van de rechtbank de aanplakking of publicatie bevelen van zijn beslissing of een samenvatting daarvan. ${ }^{195}$

De stakingsvordering wordt ingesteld en behandeld zoals in kort geding. ${ }^{196}$ Zodra bewezen is dat een einde is gemaakt aan de overtreding, kan de voorzitter van de rechtbank de opheffing van de staking bevelen. ${ }^{197}$ Wanneer een vordering tot staken van bij de strafrechter aanhangig gemaakte feiten ingesteld is, wordt over de strafvervolging pas uitspraak gedaan nadat over de vordering tot staken een in kracht van gewijsde getreden beslissing gewezen is. Tijdens de opschorting is de verjaring van de strafvordering geschorst. ${ }^{198}$

De stakingsvordering is er in wezen op gericht een bepaald verbod op te leggen. ${ }^{199}$ Veelal neemt men aan dat de rechter in het raam van een vordering tot staken enkel een positieve daad kan bevelen in zoverre deze een verbod inhoudt de gewraakte praktijk verder te zetten. ${ }^{200}$ De vordering tot staken vindt haar bevoorrecht toepassingsgebied dan ook in het beëindigen van patronen van discriminatie (bijv. het hanteren van een discriminatoir deurbeleid in dancings) en het beëindigen van het gebruik van discriminerende standaardvoorwaarden bij in de toekomst te sluiten contracten. ${ }^{20 I}$

De vordering tot staken staat niet enkel ter beschikking in de gevallen waarin een staking van de discriminerende praktijk nog kan leiden tot de creatie van een nietdiscriminatoire rechtsverhouding tussen de eiser en de verweerder. Zij staat ook ter

I93. Art. I8, § I, Antiracismewet; art. 20, § I, Antidiscriminatiewet; art. 25, § I, Genderwet.

I94. Art. I8, \ 2, Antiracismewet; art. 20, § 2, Antidiscriminatiewet; art. 23, § 2, Genderwet.

I95. Art. 20, § 3, Antiracismewet; art. 20, § 3, Antidiscriminatiewet; art. 25, § 3, Genderwet.

196. Art. I8, \$ 4, Antiracismewet en art. 20, \$ 4, eerste lid, Antidiscriminatiewet.

197. Art. 20, § I, tweede lid, Antidiscriminatiewet; art. 25, § I, tweede lid, Genderwet; art. I8, § I, tweede lid, Antiracismewet.

198. Art. I8, § 4, voorlaatste lid, Antiracismewet en art. 20, § 4, voorlaatste lid, Antidiscriminatiewet.

199. A. Van Oevelen en C. Cauffman, o.c. in Bijzondere overeenkomsten 2007-2008, nr. 77, p. 476. In die zin m.b.t. de Antidiscriminatiewet van 2003: P. Taelman, 0.c., NjW 2004, p. 508, nr. 4; -, o.c., in De Wet Bestrijding Discriminatie in de praktijk, p. 2II, nr. I3.

200. A. Van Oevelen en C. Cauffman, o.c. in Bijzondere overeenkomsten 2007-2008 nr. 77, p. 476. In die zin m.b.t. de Antidiscriminatiewet van 2003: P. Taelman, o.c., in De Wet Bestrijding Discriminatie in de praktijk, ibid.; -, o.c., NjW 2004, p. 508, nr. 4 .

20I. A. Van Oevelen en C. Cauffman, o.c. in Bijzondere overeenkomsten 2007-2008, nr. 77, p. 476. 
beschikking in de gevallen waarin een bepaalde discriminerende situatie definitief is geworden, bv. in de gevallen waarin een persoon de toegang tot een bepaalde dancing werd geweigerd of waarin het te huur gestelde goed reeds aan een derde is verhuurd. Het nut van de vordering tot staken is dan gelegen in het voorkomen van toekomstige discriminaties. ${ }^{202}$

De vraag rijst of het nut van de vordering tot staken beperkt is tot het voorkomen van toekomstige discriminaties dan wel of zij er ook toe kan leiden dat de gediscrimineerde contractpartij in een concreet geval verkrijgt wat zij in feite nastreefde, namelijk het sluiten van een concrete overeenkomst, op een niet-discriminatoire wijze en met een niet-discriminatoire inhoud. Schadevergoeding wegens het leed aangedaan door de oorspronkelijke discriminerende houding van de aanbieder kan de stakingsrechter alleszins al niet bieden. ${ }^{203}$ Maar, kan hij een verplichting opleggen om een bepaald contract te sluiten of zal een verbod om te discrimineren resulteren in een verplichting tot contractsluiting? Deze vraag wordt overwegend negatief beantwoord. Contractdwang wordt in beginsel immers niet tot de bevoegdheid van de stakingsrechter gerekend, en de Antidiscriminatiewet zou de 'zuivere' contractdwang evenmin hebben willen invoeren in het Belgische recht. ${ }^{204}$ Wanneer een contractpartij in strijd met de Antidiscriminatiewet weigert een bepaalde overeenkomst te sluiten, kan de stakingsrechter volgens de meerderheidsopvatting de weigerende partij derhalve niet dwingen de overeenkomst toch te sluiten. ${ }^{205}$ De stakingsrechter kan enkel het verbod opleggen om in de toekomst de overeenkomst met het discriminerende beding nog verder te gebruiken. ${ }^{206}$

Het Centrum voor Gelijke Kansen en Racismebestrijding meende onder de gelding van de vorige Antidiscriminatiewet dat de vordering tot staken wel soelaas kan bieden in individuele gevallen, al zal de stakingsrechter volgens het Centrum nooit iemand kunnen dwingen een bepaalde overeenkomst te sluiten of uit te voeren op een niet-discriminerende wijze. Hoogstens zal de rechter, aldus het Centrum, dit effect kunnen beogen via de dwangsom. ${ }^{207}$

202. Rb. Gent 3I december 2003, NjW 2004, 205, noot E. Brems, bevestigd door Gent 30 november 2005, RW 2006-07, I44, noot J. Kusters; C.G.K.R., Naar een uitbreiding: wees niet blind voor discriminatie. Jaarverslag 2003 (bijlagen), Brussel, CGKR, 2004, 30; D. De Prins, S. Sottiaux en J. Vrielink, o.c., p. 540 , nr. 1368 .

203. In die zin m.b.t. de Antidiscriminatiewet van 2003: P. Taelman, o.c., in De Wet Bestrijding Discriminatie in de praktijk, p. $2 \mathrm{I}_{2}$, nr. $\mathrm{I} 3$.

204. In die zin m.b.t. de Antidiscriminatiewet van 2003: A. De Boeck, 'Doorwerking van het gelijkheidsbeginsel in het contractenrecht, de contractvrijheid in het nauw gedreven?', in Vrijheid en gelijkheid. De horizontale werking van het gelijkheidsbeginsel en de nieuwe Antidiscriminatiewet, Antwerpen, Maklu, 2003, 437 en 439-440; M. Dambre, 'De Wet bestrijding discriminatie en het huurrecht', in De Wet Bestrijding Discriminatie in de praktijk, p. 342, nr. 44; P. Taelman, o.c., in De Wet Bestrijding Discriminatie in de praktijk, p. 2II-2I2, nr. I3; K. Vanderschot, o.c., in, Antidiscriminatiewet en contracten, p. 57-58, nr. 25 .

205. In die zin m.b.t. de Antidiscriminatiewet van 2003: D. De Prins, 'Stakingsvordering tegen individuele discriminatie', NjW 2004, p. 262, nrs. 8-9; P. Taelman, o.c., NjW 2004, p. 508, nr. 4; -, o.c., in De Wet Bestrijding Discriminatie in de praktijk, p. 2I2, nr. I3; K. Vanderschot, ibid.

206. P. Taelman, o.c., in M. De Vos en E. Brems (eds.), DeWet Bestrijding Discriminatie in de praktijk, p. 2II, nr. 13 .

207. C.G.K.R., Naar een uitbreiding. Jaarverslag 2003 (bijlagen), 29. 
Enkele auteurs menen dat het 'bevel tot staking van iets niet te doen' logischerwijze resulteert in de plicht om iets wel te doen en dat deze plicht in bepaalde omstandigheden vatbaar is voor uitvoering in natura. ${ }^{208}$ Dit zou bijvoorbeeld het geval zijn wanneer de positie van de verhuurder neigt naar een absolute machtspositie, wanneer de verhuurder een taak bekleedt gelijkwaardig aan die van de overheid of wanneer de wederzijdse onderhandelingen reeds in een zodanig stadium gevorderd waren dat bij de wederpartij het gewettigde vertrouwen was gewekt dat een contract zou worden gesloten, wat enkel onderbroken werd bij de veruitwendiging van een bepaald kenmerk (bv. nationaliteit) van de huurder. ${ }^{209}$ Ook bepaalde rechterlijke beslissingen hebben partijen tot contractsluiting gedwongen. ${ }^{210}$

\subsubsection{Dwangsom}

De rechter kan op verzoek van het slachtoffer van de discriminatie, van het Centrum, van een van de belangenverenigingen, of van het openbaar ministerie of het arbeidsauditoraat diegene die de discriminatie heeft gepleegd, veroordelen tot de betaling van een dwangsom wanneer aan die discriminatie geen einde is gemaakt. De rechter doet uitspraak overeenkomstig de artikelen 1385 bis tot 1385 nonies van het Gerechtelijk Wetboek.

Met betrekking tot de gelijksoortige bepaling in de vorige Antidiscriminatiewet werd aangenomen dat ook deze bepaling (wellicht) geen werkelijke contractdwang heeft willen mogelijk maken. ${ }^{211}$ Het opleggen van een dwangsom zou er eerder toe leiden dat de inhoud van het contract zal worden aangepast. ${ }^{212}$ Het belang van de mogelijkheid tot het opleggen van een dwangsom zou hoofdzakelijk gelegen zijn op het vlak van praktijken die inhouden dat (standaard)contracten worden aangeboden met discriminatoire voorwaarden. ${ }^{213}$

208. Vgl. J. Stuyck, I. Buelens en D. Counye, o.c., TBH I995, p. 800 e.v., nrs. 30 e.v.; J. Stuyck, 'De vordering tot staking : samenloopregels en uitvoering van het bevel tot staking', in J. Stuyck e.a. (ed.), Handelspraktijken anno 1996, Antwerpen, Kluwer, I996, p. 263-264, nrs. 75-76: de stakingsrechter kan de verplichting opleggen om met de afnemer een contract te sluiten waartoe hij vrijwillig niet bereid was, zij het slechts voorlopig en in afwachting van een uitspraak ten gronde. Contra: Brussel 3I mei I988, TBH I989, 7II, dat in het raam van de wet Handelspraktijken oordeelde dat de stakingsrechter door de staking te bevelen van een onrechtmatige verkoopsweigering de verweerder niet onrechtstreeks verplicht een contract aan te gaan; hij verbiedt enkel onrechtmatig te weigeren. Zijn bevel is m.a.w. geen bevel tot contracteren, maar een bevel om op de markt op te treden zonder discriminatie of willekeur of enige miskenning van een positieve norm.

209. J. Kusters, 'Discriminatie ten opzichte van allochtonen op de private huurmarkt', in Vrijheid en gelijkheid, 566-567. Zie ook : M. Dambre, o.c., De Wet Bestrijding Discriminatie in de praktijk, p. 346, nr. 58 .

2I0. Brussel I7 mei I990, JHPM I990, 220; Voorz. Kh. Luik 3 mei I990, JHPM I990, 346. Zie ook: Y. Thiery, 'De Antidiscriminatiewet : verzekeren over dezelfde kam?', TBH 2003, nr. 5I, p. 659.

2II. A. De Boeck, o.c., in Vrijheid en gelijkheid, 439-440; D. De Prins, o.c., NjW 2004, nrs. 7-9, p. 262; M. Dambre, o.c., in De Wet Bestrijding Discriminatie in de praktijk, nrs. 57 e.v., p. 346 e.v.; K. Vanderschot, o.c., in Antidiscriminatiewet en contracten, nr. 25, p. 57-58.

212. A. De Boeck, o.c., in Vrijheid en gelijkheid, 440; K. Vanderschot, o.c., in Antidiscriminatiewet en contracten, nr. 25, p. 58 . Zie ook over de dwangsom en contractweigering: M. Dambre, o.c., in De Wet Bestrijding Discriminatie in de praktijk, nrs. 57-6o, p. 346.

213. En dus niet zozeer bij (individuele gevallen van) contractweigering (A. De Boeck, o.c. in Vrijheid en gelijkheid, 439-440; K. Vanderschot, ibid. Zie ook: D. De Prins, o.c., NjW 2004, nrs. 7-9, p. 262). 


\subsubsection{Omkering van de bewijslast}

In het raam van alle gerechtelijke procedures, met uitzondering van de strafrechtelijke procedures, is voorzien in de mogelijkheid tot omkering van de bewijslast inzake discriminatie. ${ }^{214}$ Wanneer de eiser voor het bevoegde rechtscollege feiten aanvoert die het bestaan van een discriminatie op grond van een van de beschermde criteria kunnen doen vermoeden, dient de verweerder te bewijzen dat er geen discriminatie is geweest. ${ }^{215}$ De omkering van de bewijslast is m.a.w. geen automatisme; de eiser dient eerst feiten aan te voeren die het bestaan van discriminatie kunnen doen vermoeden. Dit bewijs, dat betrekking heeft op een rechtsfeit, mag met alle middelen van recht worden geleverd. ${ }^{216}$

Onder feiten die het bestaan van een directe discriminatie op grond van een beschermd criterium kunnen doen vermoeden, wordt onder meer, maar niet uitsluitend, begrepen:

$\mathrm{I}^{\circ}$ de gegevens waaruit een bepaald patroon van ongunstige behandeling blijkt ten aanzien van personen die drager zijn van een welbepaald beschermd criterium, onder meer verschillende, los van elkaar staande bij het Centrum voor Gelijke Kansen en Racismebestrijding, het Instituut voor gelijkheid van vrouwen en mannen of een van de belangenverenigingen gedane meldingen; of

$2^{\circ}$ de gegevens waaruit blijkt dat de situatie van het slachtoffer van de ongunstigere behandeling, vergelijkbaar is met de situatie van de referentiepersoon. ${ }^{217}$

Onder feiten die het bestaan van een indirecte discriminatie op grond van een beschermd criterium kunnen doen vermoeden, wordt onder andere, maar niet uitsluitend, begrepen :

$\mathrm{I}^{\circ}$ algemene statistieken over de situatie van de groep waartoe het slachtoffer van de discriminatie behoort of feiten van algemene bekendheid; of

$2^{\circ}$ het gebruik van een intrinsiek verdacht criterium van onderscheid; of

$3^{\circ}$ elementair statistisch materiaal waaruit een ongunstige behandeling blijkt. ${ }^{218}$

\subsubsection{Bescherming tegen represailles}

Wanneer een klacht wordt ingediend door of ten voordele van een persoon wegens een schending van de Antidiscriminatie-, Antiracisme of Genderwet op een ander terrein dan dat van de arbeidsbetrekkingen en de aanvullende regelingen voor sociale zekerheid, mogen zij tegen wie de klacht is ingediend geen nadelige maatregel treffen ten aanzien van de betrokkene, behalve om redenen die vreemd zijn aan de klacht.

Wanneer een nadelige maatregel wordt getroffen ten aanzien van de betrokkene binnen twaalf maanden na het indienen van de klacht, valt de bewijslast dat de

2I4. Art. 27-28 Antidiscriminatiewet; art. 29-30 Antiracismewet; art. 32-33 Genderwet.

215. Art. 28, § I, Antidiscriminatiewet; art. 30, § I, Antiracismewet; 33, § I, Genderwet.

2I6. In die zin voor de Antidiscriminatiewet van 25 februari 2003: P. Taelman, o.c., in De Wet Bestrijding Discriminatie in de praktijk, nr. 55, p. $25 \mathrm{I}$.

217. Art. 28, § 2, Antidiscriminatiewet; art. 30, § 2, Antiracismewet; art. 33, § 2, Genderwet.

218. Art. 28, § 3, Antidiscriminatiewet, art. 30, § 3, Antiracismewet; art. 33, § 3, Genderwet. 
nadelige maatregel werd getroffen om redenen die vreemd zijn aan de klacht, ten laste van diegene tegen wie de klacht is ingediend. Indien een rechtsvordering door of ten voordele van de betrokkene werd ingesteld, wordt de periode van 12 maanden verlengd tot drie maanden na de dag waarop de rechterlijke beslissing in kracht van gewijsde is getreden. Op vraag van de verweerder kan deze termijn evenwel ingekort worden.

Wanneer degene tegen wie een klacht is ingediend niettemin een nadelige maatregel neemt die niet vreemd is aan de klacht, moet hij die de maatregel genomen heeft, aan de betrokkene naar keuze van deze persoon hetzij een forfaitaire schadevergoeding betalen, hetzij een schadevergoeding die overeenstemt met de werkelijk door die persoon geleden schade. In laatstgenoemd geval moet de betrokkene de omvang van de geleden schade bewijzen.

Dezelfde bescherming geldt voor personen die als getuige optreden doordat zij in het kader van het onderzoek van een klacht, in een ondertekend en gedateerd document de feiten die zij zelf hebben gezien of gehoord en die betrekking hebben op de toestand die het voorwerp is van de klacht, ter kennis brengen van de persoon bij wie de klacht wordt ingediend, of doordat zij optreden als getuige in rechte (artikel I6 $§ 5$ Antidiscriminatiewet, art. I4 § 5 Genderwet, art. I4 § 5 Antiracismewet).

Voor klachten met betrekking tot discriminatie op het vlak van de arbeidsbetrekkingen en de aanvullende regelingen voor sociale zekerheid, geldt een gelijkaardige regeling (artikel 17 Antidiscriminatiewet, art. 22 Genderwet, art. I5 Antiracismewet).

\subsection{Milieurecht}

\subsubsection{Algemeen}

De milieuwetgeving in het Belgische recht is, zeker gelet op de federale staatsstructuur, erg complex en werd op vlak van de handhaving tot voor kort gekenmerkt door een grote diversiteit. De niet-naleving ervan werd in het verleden voornamelijk aangepakt via strafrechtelijke weg, waardoor de parketten in principe met zeer veel dossiers konden worden belast. De praktijk wees uit dat er de facto weinig strafrechtelijk werd opgetreden. ${ }^{219}$ De sanctionering was bovendien erg uiteenlopend, omdat er geen eenduidigheid bestond over de strafbaarstelling en de strafmaat. Milieumisdrijven werden voornamelijk aangepakt via sectorale wetten en decreten. Hierdoor verkreeg het handhavingsbeleid in het milieurecht een sterk casuïstisch karakter. ${ }^{220}$ Om deze reden werd de handhaving van de milieuwetgeving als een kernopdracht vermeld in het Vlaamse regeerakkoord van 2004. ${ }^{22 \mathrm{I}}$

2I9. C. Billiet en S. Rousseau, 'Zachte rechtshandhaving in het bestuurlijke handhavingsspoor: de inspectiebeslissing en het voortraject van bestuurlijke sancties. Een rechtseconomische analyse', TMR 2005, I7.

220. M. Faure, K. Deketelaere, J. Heyman, S. Ubachs, J. Vanheule, F. Verbruggen en M. Visser, Schets van een nieuw Vlaams milieustrafrecht, Brugge, die Keure, 2004, 58.

22I. Zie Persmededeling van het kabinet van minister Hilde Crevits, Vlaams minister van Openbare Werken, Energie, Leefmilieu en Natuur, I6 april 2009. 
Het Vlaams Parlement keurde op I2 december 2007 het Milieuhandhavingsdecreet $^{222}$ goed, dat op I mei 2009 in werking is getreden. In dit decreet komen twee belangrijke aspecten aan bod. Het eerste aspect betreft het beleid en de organisatie van de milieuhandhaving. ${ }^{223}$ Het tweede aspect omvat een verregaande harmonisatie van het toezicht, het handhavingsinstrumentarium en de veiligheidsmaatregelen.

Het Milieuhandhavingsdecreet heeft als uitgangspunt gekozen voor de publiekrechtelijke handhaving, waaraan de voorrang wordt gegeven boven de privaatrechtelijke handhaving. Niettemin blijven ook in het milieurecht elementen van privaatrechtelijke rechtshandhaving aanwezig. Zij komen hierna aan bod.

\subsubsection{Vordering tot staken}

Zoals in vele andere rechtsdomeinen voerde de Belgische wetgever ook in het milieurecht een stakingsvordering in. Dit geschiedde bij wet van I2 januari 1993 betreffende een vorderingsrecht inzake bescherming van het leefmilieu. ${ }^{224}$ De wet kent aan milieuverenigingen, administratieve overheden en de procureurs des Konings een vorderingsrecht recht toe om staking te bekomen van handelingen die een kennelijke inbreuk zijn of een ernstige dreiging vormen voor inbreuken op wetgeving betreffende de bescherming van het leefmilieu. Het verzoek wordt overeenkomstig artikel I van de wet gericht aan de Voorzitter van de rechtbank van eerste aanleg, die de inbreuk of de dreiging kan vaststellen. Vervolgens kan hij de staking van de handeling bevelen of maatregelen opleggen ter preventie van de uitvoering ervan of ter voorkoming van schade ${ }^{225}$ aan het leefmilieu.

De in de wet uitgewerkte procedure is er aldus niet op gericht schadevergoeding toe te kennen. ${ }^{226}$ Het betreft daarentegen een procedure zoals in kort geding die er in hoofdzaak toe strekt de staking te verkrijgen van kennelijke inbreuken op de milieuwetgeving of de ernstige dreiging daarvan.

Op I april $2007^{227}$ werd in de Senaat een wetsvoorstel ${ }^{228}$ ingediend tot wijziging van de wet van 12 januari 1993 , dat evenwel geen wet is geworden.

Ook particulieren hebben via de wet van 12 januari 1993 de mogelijkheid om een stakingsvordering in te stellen in milieuaangelegenheden. Artikel 27I § I N.Gem.W.

222. Decr.Vl. 2I december 2007 tot aanvulling van het decreet van 5 april I995 houdende algemene bepalingen inzake milieubeleid met een titel XVI 'Toezicht, handhaving en veiligheidsmaatregelen', BS 29 februari 2008.

223. Zie J. Heyman en K. Deketelaere, 'Het Vlaams decreet betreffende milieuhandhaving', in K. Deketelaere (ed.), Jaarboek milieurecht 2007, Brugge, die Keure, 2008, 225 e.v.

224. BS ig februari i993.

225. Zoals bevestigd door het Hof van Cassatie: Cass. 8 november I996, TMR I99I, 30, noot J. Van Den Berghe.

226. I. Demuynck, 'Rechtshandhaving door de stakingsrechter in milieuaangelegenheden', RW 200I-02, I487.

227. Parl. St. Senaat 2006-2007, nr. 3-2442/I.

228. Voor een bespreking ervan, zie M. Melis, 'Recente ontwikkelingen inzake toegang tot milieuinformatie, participatie bij milieubesluitvorming en toegang tot de rechter in milieuzaken', in Jaarboek milieurecht 2007, 2 Io e.v. 
bepaalt dat wanneer het college van Burgemeester en Schepenen, naliet in rechte op te treden, een of meer bewoners namens de gemeente in rechte konden optreden, mits zij onder zekerheidsstelling aanboden persoonlijk de kosten van het geding te dragen en in te staan voor eventuele veroordelingen. Dit artikel werd opgeheven ${ }^{229}$ maar overgenomen door artikel 194 van het Gemeentedecreet. De gemeente is een administratieve overheid, wat betekent dat zij een stakingsvordering kan instellen conform de wet van I2 januari I993. Wanneer de gemeente dat nalaat, kunnen inwoners van de gemeente dat in haar plaats doen. ${ }^{230}$

Het Arbitragehof heeft in een arrest van 26 april 2007 voorts bepaald dat een gemeente die een vergunning of een gunstig advies verleend heeft, niettemin toch een stakingsvordering kan instellen tegen een handeling die daarmee in overeenstemming is. De aanleiding was het aangevoerde verschil in behandeling tussen twee inwoners van de gemeente, die beiden op grond van artikel 27 I $§$ I N.Gem.W. een vordering instelden. De ene klaagde een handeling aan die strijdig was met een door de gemeente verleende vergunning of advies en de andere kwam op tegen een handeling die in overeenstemming was met die vergunning of dat advies. De inwoner van de gemeente die dus in naam van de gemeente opkomt tegen een handeling conform de door die gemeente verleende vergunning of advies, heeft daartoe het vereiste belang. ${ }^{23 \mathrm{I}}$

\subsubsection{Burenhinder}

In het Kanaal- en Schoorsteenarrest van 6 april I96o oordeelde het Hof van Cassatie dat de eigenaar van een onroerend goed die door een niet-foutief feit aan een naburige eigenaar een stoornis oplegt die de maat van de gewone buurschapsnadelen overschrijdt, hem een rechtmatige en passende compensatie verschuldigd is waardoor het evenwicht wordt hersteld. ${ }^{232}$ Het bewijs van een fout is aldus niet vereist, ${ }^{233}$ maar wel van een bovenmatige hinder. Het slachtoffer zal overlast moeten aantonen, wat per definitie een subjectief begrip is. De inhoud zal voornamelijk afhankelijk zijn van de plaats en het moment van de schadeverwekkende feiten. ${ }^{234}$ De sanctie omvat geen integrale schadevergoeding, maar wel een passende compensatie. Dat zal meestal ook een schadevergoeding zijn ter compensatie van het leed, maar kan ook ruimer zijn. ${ }^{235}$ Zo oordeelde het hof van beroep te Brussel dat de uitbater van een plantenkwekerij het slachtoffer was geworden van burenhinder, doordat verschillende cementfabrieken zich in zijn buurt hadden gevestigd. Door de

229. Door art. 302, I67 van het Vlaamse Gemeentedecreet van I5 juli 2005, BS 3I augustus 2005.

230. Cass. I4 februari 2002, RW 200I-02, 1503.

23I. Arbitragehof nr. 70/2007 26 april 2007, www.grondwettelijkhof.be, bevestigd door Grondwettelijk Hof nr. I2I/2007, Ig september 2007, www.grondwettelijkhof.be. Zie M. Melis, o.c., in Jaarboek milieurecht 2007, 214-2I7.

232. Cass. 6 april ig6o, Arr.Cass. i960, 722.

233. V. Sagaert, 'Verantwoordelijkheid en eigendom: het aansprakelijkheidsrecht op zijn kop?', in UALS (ed.), Verantwoordelijkheid en recht, Mechelen, Kluwer, 2008, 74.

234. H. Bocken, 'Aansprakelijkheid en milieubescherming', R.W. I974, II42.

235. S. Stijns en H. Vuye, Beginselen van Belgisch privaat recht, Zakenrecht, Boek IV Burenhinder, Gent, Story Scientia, 2000, 500 e.v. 
vervuiling die deze industrie met zich meebracht, was hij genoodzaakt te verhuizen. Het hof oordeelde dat de verhuiskosten ook ten laste kwamen van de vervuilers. ${ }^{236}$

\subsubsection{Milieuaansprakelijkheid}

Vanuit theoretisch oogpunt omvat de foutaansprakelijkheid een efficiënt instrument tegen de verstoring van het leefmilieu. Wanneer de benadeelde de fout, de schade en het causaal verband tussen beide bewijst, moet de schade integraal worden vergoed. Niettemin moet worden gewezen op enkele beperkingen. ${ }^{237}$ Zo is de bewijslast van het slachtoffer erg zwaar. Wanneer bijvoorbeeld een bedrijf de vereiste vergunningen heeft voor haar activiteiten, zal het aantonen van de fout niet eenvoudig zijn. ${ }^{238}$ Uiteindelijk behoort de feitenrechter voornamelijk een waardeoordeel te maken. ${ }^{239}$ Ook het bewijzen van het causaal verband is erg moeilijk. Wie bijvoorbeeld beweert gezondheidsschade te lijden door een bepaald product of activiteit, zal vaak precies op dit vlak falen. Veelal zal de schade immers ook andere oorzaken kunnen hebben. Hoe kan je immers daadwerkelijk aantonen dat je bijvoorbeeld kanker hebt gekregen door de nabijheid van een verbrandingsoven? ${ }^{240}$

In een aantal domeinen werd de positie van het slachtoffer verbeterd door het invoeren van objectieve aansprakelijkheden. Een voorbeeld betreft de wet van 22 juli $1985^{24 \mathrm{I}}$ betreffende de wettelijke aansprakelijkheid op het gebied van kernenergie, ${ }^{242}$ zoals gewijzigd door de wet van II juli 2000. ${ }^{243}$ Deze wet voorziet in een objectieve aansprakelijkheid van de exploitant van een nucleaire installatie voor de door een kernongeval veroorzaakte schade. De slachtoffers moeten geen foutbewijs leveren. Deze aansprakelijkheid is gekoppeld aan een verzekeringsplicht en een korte verjaringstermijn. ${ }^{244}$ Een dergelijke verzekeringsplicht is in elk geval noodzakelijk om de objectieve aansprakelijkheden financieel beheersbaar te houden.

236. Brussel 26 mei ig6r, Ann.not.Ebr. I96r, 239, noot J. Haulot.

237. Zie H. Bocken, o.c., RW I974, II26.

238. H. Bocken, Preventie, toerekening en herstel van schade door milieuverontreiniging, Deventer, Kluwer, I983, 48 .

239. H. Bocken, 'Santions de droit civil contra la pollution', T.Aann. 1975, 70.

240. Hierover: S. Lierman, o.c., 2004, 428 e.v.

24I. BS 3 I augustus I985, err. BS 4 oktober 2000.

242. Voor een volledige analyse van de aansprakelijkheid door kernongevallen, zie T. Vanden Borre, Efficiënte preventie en compensatie van catastroferisico's. Het voorbeeld van schade door kernongevallen, Antwerpen, Intersentia, 200I, XXIV +835 p.

243. BS. 4 oktober 2000.

244. S. Lierman, Voorzorg, preventie en aansprakelijkheid, 256 e.v. 
Tot slot moet erop worden gewezen dat de Richtlijn Milieuschade 2004/35 245 door het Vlaamse $\mathrm{e}^{246}$ en Waalse $\mathrm{e}^{247}$ Milieuschadedecreet werd omgezet in het Belgische recht. Het uitgangspunt van de richtlijn is het principe 'de vervuiler betaalt'. Dit vormt de leidraad bij de regeling inzake het voorkomen en herstellen van de milieuschade, met de klemtoon op de schade die veroorzaakt wordt door beroepsactiviteiten. Meer bepaald zal de exploitant bij milieuschade of dreigende milieuschade verplicht zijn om op zijn kosten herstelacties of preventieve acties uit te voeren. ${ }^{248}$

\subsection{Intellectuele rechten}

\subsubsection{Wetgeving}

De titel van Richtlijn 2004/48/EG van 29 april 2004 is veelzeggend. Zij betreft 'de handhaving van intellectueleeigendomsrechten'. Uit de preambule van de richtlijn blijkt duidelijk dat met de bedoelde 'handhaving' niet louter privaatrechtelijke belangen worden nagestreefd. Reeds in de eerste inleidende overweging wordt erop gewezen dat '[d]e bescherming van de intellectuele eigendom' niet alleen van belang is 'voor het bevorderen van innovatie en creativiteit, maar ook voor de ontwikkeling van de werkgelegenheid en de verbetering van het concurrentievermogen'. 'Afhankelijk van het geval en zo de omstandigheden het rechtvaardigen, moeten de vast te stellen maatregelen, procedures en rechtsmiddelen' aldus overweging 24 van de preambule 'verbodsmaatregelen omvatten ter voorkoming van nieuwe inbreuken op intellectueleeigendomsrechten'. De te nemen maatregelen dienen dus (o.m.) een preventief doel. De te nemen maatregelen dienen overeenkomstig artikel 3 Richtlijn 'doeltreffend, evenredig en afschrikkend zijn'. De door de richtlijn beoogde maatregelen zijn voornamelijk van civielrechtelijke aard en betreffen o.m. de bewijsgaring, het stakingsbevel en schadevergoeding. Het strafrechtelijk luik dat deel uitmaakte van de ontwerprichtlijn werd op advies van het Europees parlement geschrapt. ${ }^{249}$

245. Richtlijn 2004/35 van 2I april 2004 betreffende milieuaansprakelijkheid met betrekking tot het voorkomen en herstellen van milieuschade, $\mathrm{Pb} \mathrm{L} 30$ april 2004 gewijzigd bij richtlijn 2006/2I/ EG van 15 maart 2006 betreffende het beheer van afval van winningsindustrieën en houdende wijziging van Richtlijn 2004/35, Pb L II april 2006.

246. Decreet van 2I december 2007 tot aanvulling van het decreet van 5 april 1995 houdende algemene bepalingen inzake milieubeleid met een titel XVI 'Milieuschade', BS 2I februari 2008.

247. Decreet van 22 november 2007 tot wijziging van Boek I van het Milieuwetboek met betrekking tot het voorkomen en herstellen van milieuschade, BS ig december 2007.

248. Zie voor Vlaanderen H. Deschamps, 'De implementatie van de Europese Milieuschaderichtlijn door de federale en gewestelijke overheden in België', in Jaarboek milieurecht 2007, 68 e.v. en voor Wallonië: M. Boodts, 'Recente ontwikkelingen in het Waals en Brussels milieurecht', in Jaarboek milieurecht 2007, I25 e.v.

249. Verslag van 5 december 2003 over het voorstel voor een richtlijn van het Europees Parlement en de Raad betreffende de maatregelen en procedures om de handhaving van intellectueleeigendomsrechten te waarborgen (COM(2003)46 - C5-0055/2003-2003/0024(COD)) www.europarl. europa.eu/sides/getDoc.do?type $=$ REPORT\&reference $=A 5-2003-0468 \&$ format $=X M L \&$ language $=$ NL; Debatten van het Europees Parlement van dinsdag 9 maart 2004, www. europarl.europa.eu/sides/getDoc.do?type $=$ CRE\&reference $=20040309 \&$ secondRef $=I T E M-$ $003 \&$ format $=$ XML\&language $=$ NL. 
De Handhavingsrichtlijn ${ }^{25} \mathrm{nr} .2004 / 48^{25 \mathrm{I}}$ werd in het Belgische recht omgezet door drie recente wetten:

- de wet van 9 mei 2007 betreffende de burgerrechtelijke aspecten van de bescherming van de intellectuele eigendomsrechten

- de wet van Io mei 2007 betreffende de aspecten van gerechtelijk recht van de bescherming van intellectuele eigendomsrechten

- de wet van 15 mei 2007 betreffende de bestraffing van namaak en piraterij van intellectuele eigendomsrechten

De rode draad doorheen deze wetten is het nastreven van harmonisatie in het volledige domein van de intellectuele rechten op verschillende gebieden: de concentratie van bevoegdheden van de rechtbanken, de harmonisatie van de rechtshandhaving en de sancties en het wegwerken van procedurele hindernissen die voortvloeiden uit het samenspel tussen de intellectuele rechten onderling en het gemeen recht inzake onrechtmatige mededinging. ${ }^{252}$ De keuze voor de privaatrechtelijke handhaving valt daarbij op, hoewel de wetgever ook strafrechtelijke sancties heeft behouden tot de handhaving van intellectuele rechten. Daartoe werd de vermelde wet van i5 mei 2007 uitgevaardigd, die de harmonisatie beoogt van de strafrechtelijke aanpak van intellectuele eigendomsrechtinbreuken. ${ }^{253}$ In wat volgt zal evenwel de privaatrechtelijke handhaving van de intellectuele rechten worden bekeken.

\subsubsection{Vordering tot beschrijuing en/of beslag van de namaak}

Deze civielrechtelijke procedure bestaat reeds lang in het Belgische recht, nu zowel de Octrooiwet van I854 als de Auteurswet van I886 deze procedure voorzien. Meer bepaald vormde ze een onderdeel van de regels inzake het conservatoir beslag, waarbij artikel I484 Ger. W. op limitatieve wijze opsomde welke personen gerechtigd waren om een dergelijke procedure in te stellen. Het ging meer bepaald over de houders van octrooien, de houders van een aanvullend beschermingscertificaat, de houders en aanvragers van kwekerscertificaten, hun rechthebbenden, de houders van het auteursrecht en de houders van een naburig recht, met inbegrip van de producenten van databanken. Deze limitatieve opsomming was het voorwerp van kritiek in de rechtsleer, ${ }^{254}$ maar ook in de rechtspraak van het Arbitragehof. Dat hof

250. Zie o.a. A. Puttemans, 'Les droits intellectuels en action(s)', in P. Jadoul en A. Strowel (eds.), Les droits intellectuels : développements récents, Brussel, Larcier, 2004, 7 e.v.; de bijdragen verschenen in M.C Janssens (ed.), Beteugeling van inbreuken op intellectuele rechten, Brussel, Bruylant, 2004, $\mathrm{VI}+2 \mathrm{I} 3 \mathrm{p}$.

25I. Europese Richtlijn nr. 2004/48/EG van 29 april 2004 betreffende de handhaving van intellectuele eigendomsrechten, $\mathrm{Pb} \mathrm{L} 30$ april 2004.

252. B. Michaux en E. De Gryse, 'De handhaving van intellectuele rechten gereorganiseerd', TBH 2007, 624 .

253. Zie J. Deene, 'De bestrijding van namaak en piraterij', IR DI 2007, 346 e.v.; B. Michaux en E. De Gryse, o.c., TBH 2007, 643 e.v.; M.C. Janssens, 'Drie wetten inzake handhaving van intellectuele rechten openen nieuwe horizonten in de strijd tegen namaak en piraterij', RW 2007-08, 942 e.v.

254. Zie hierover: K. Roox, 'De nieuwe bevoegdheidsregeling in het intellectueel eigendomsrecht (deel II)', IR DI 2008, io e.v. 
oordeelde dat de uitsluiting van merkhouders uit het toepassingsgebied van artikel I48I Ger.W. niet redelijk verantwoord was, in de mate dat aan de houders van het merkrecht een doeltreffend middel wordt ontzegd om hun rechten te vrijwaren. ${ }^{255}$

De wet van Io mei 2007 is tegemoet gekomen aan deze kritiek: de procedure werd geplaatst in een afzonderlijke titel 'beslag inzake namaak' van het Ger.W. (art. I48I e.v.) en tevens opengesteld voor alle houders van intellectuele rechten..$^{256}$

De doelstelling van deze procedure is voornamelijk bewijsrechtelijk van aard. Het beslag inzake namaak strekt er hoofdzakelijk toe het bewijs van namaak te verkrijgen en niet zozeer - zoals de titel doet vermoeden - een beslag tot stand te brengen. ${ }^{257}$ Namaak mag weliswaar worden bewezen met alle middelen van recht, maar dat neemt niet weg dat er in de praktijk vaak bewijsproblemen ontstaan. Deze procedure moet het leveren van het bewijs vereenvoudigen en bestaat erin dat de verzoeker aan de voorzitter van de rechtbank van koophandel of de voorzitter van de rechtbank van eerste aanleg via een eenzijdig verzoekschrift de toestemming vraagt om door een of meer deskundigen die de voorzitter aanstelt, over te gaan tot de beschrijuing van alle voorwerpen, elementen, documenten of werkwijzen die van aard zijn de beweerde namaak, alsook de oorsprong, de bestemming en de omvang ervan aan te tonen (art. I36gbis/I, § I Ger.W.). ${ }^{25}{ }^{8}$ Deze lijst is niet limitatief. Alle elementen die van die aard zijn om het bestaan, de herkomst, de bestemming en de omvang van de namaak te kunnen aantonen, kunnen worden beschreven door de deskundigen. ${ }^{259}$

De memorie van toelichting beklemtoont inderdaad dat deze beschrijving het hoofddoel is van deze procedure, ${ }^{260}$ hoewel de verzoeker ook het beslag kan vorderen. De voorwaarden ${ }^{26 \mathrm{I}}$ voor de toekenning van enerzijds de beschrijvende maatregelen en anderzijds de beslagmaatregelen zijn verschillend. De voorzitter zal de beschrijving toestaan wanneer het ingeroepen intellectueel eigendomsrecht ogenschijnlijk geldig is en als er aanwijzingen bestaan van een inbreuk of een dreiging van een inbreuk. De toekenning van beslagmaatregelen onderstelt bijkomend dat de voorzitter vaststelt dat de inbreuk niet redelijkerwijze kan worden betwist en dat de gevraagde maatregel redelijk voorkomt.

De wetgever gaat er terecht van uit dat de rol van de deskundige belangrijk is. In het verleden gebeurde het meer dan eens dat de procedure werd misbruikt om aan vertrouwelijke informatie te geraken over de tegenpartij. Bijgevolg is het noodzakelijk dat de deskundige objectief is, dat zijn taak nauwkeurig wordt omschreven door de

255. Arbitragehof nr. 53/2004, 24 maart 2004, BS 29 juni 2004, JT 2004, 615, noot P. Peters en TBH 2004, 530, noot A. Puttemans. Zie in dezelfde zin met betrekking tot het modellenrecht: Arbitragehof nr. 97/2007 27 juni 2007, BS 2 augustus 2007.

256. M.C. Janssens, 'Wie kan de vordering(en) tot handhaving van intellectuele rechten instellen?', in F. Brison (ed.), Sancties en procedures in intellectuele rechten, Brussel, Larcier, 2008, 60-62.

257. K. Roox, o.c., IR DI 2008, 8.

258. B. Michaux en E. De Gryse, o.c., TBH $2007,629$.

259. Parl.St. Kamer 2006-07, nr. 5I-2943/0oI en nr. 5I-2944/00I.

260. Parl.St. Kamer 2006-07, nr. 5I-2943/0or en nr. 5I-2944/0oI.

26r. Zie o.a. F. De Visscher, 'La preuve des atteintes aux droits de propriété intellectuelle - Réforme de la saisie-description (articles 6 à 8 de la directive 2004/48)', in Sancties en procedures in intellectuele rechten, I6r e.v. 
voorzitter en dat hij de nodige verantwoordelijkheid in acht neemt bij de uitvoering van zijn taak. ${ }^{262}$

De procedure wordt steeds gekenmerkt door haar eenzijdig karakter en beantwoordt zo aan de finaliteit ervan. ${ }^{263}$ Het betreft hoofdzakelijk een bewijsmaatregel zodat er een zeker verrassingseffect moet kunnen spelen. Anders zou het risico bestaan dat er reeds bewijselementen zouden 'verdwenen' zijn vooraleer de procedure uitwerking zou kunnen krijgen. ${ }^{264}$

De wetgever heeft niettemin dit eenzijdige karakter afgezwakt door in artikel I36gbis § 4 tweede lid Ger.W. de mogelijkheid te voorzien om de tegenpartij te horen. Deze mogelijkheid bestaat enkel wanneer beslag wordt gevraagd en dus niet wanneer uitsluitend een beschrijving wordt gevorderd. Het horen van de tegenpartij zal plaatsvinden in de raadkamer in aanwezigheid van de verzoeker. In de rechtsleer werden vragen gesteld bij deze 'hoormogelijkheid' omdat hiermee het verrassingseffect uiteraard teniet wordt gedaan. De vraag rijst of de procedure in zo'n geval dan nog wel zin heeft, wat de wetgever lijkt in te zien. ${ }^{26}$ Voorafgaandelijk aan de beslissing tot verhoor zal de verzoeker hierover immers worden ingelicht en heeft hij de mogelijkheid om eventueel zijn vraag tot beslag in te trekken. Bepaalde auteurs stellen andere oplossingen voor, zoals de invoering van een voorwaardelijk effectief beslag. ${ }^{266}$ Niettemin valt er ook wel iets te zeggen voor deze mogelijkheid om de tegenpartij te horen. Het mag immers niet de bedoeling zijn dat de procedure wordt gebruikt om de concurrentie als het ware uit te schakelen in plaats van als effectieve bewijsmaatregel.

\subsubsection{Vordering tot staken}

De vordering tot staken ${ }^{267}$ is erop gericht de inbreuk op een intellectueel eigendomsrecht stop te zetten. Het valt op dat een verzoeker via verschillende wegen de staking kan laten bevelen, hetzij via een procedure ten gronde hetzij via een procedure zoals in kort geding. ${ }^{268}$

Via de procedure ten gronde kan de vordering inzake namaak worden ingesteld. Om op dit vlak uniformiteit te creëren, heeft de wetgever in alle wetten inzake intellectuele eigendom een zelfde bepaling ingelast. ${ }^{269}$ Deze luidt dat 'de rechter tegenover elke inbreukmaker de staking van de inbreuk beveelt wanneer de rechter een inbreuk op (...) vaststelt'. De procedurele regels die het Ger.W. voorschrijft voor de procedures ten gronde, zullen van toepassing zijn.

262. B. Michaux en E. De Gryse, o.c., ТВH $2007,628$.

263. F. De Visscher, o.c., in Sancties en procedures in intellectuele rechten, 173.

264. M.C. Janssens, o.c., RW 2007-08, 936-937.

265. M.C. Janssens, o.c., RW 2007-08, 937.

266. Zie o.a. K. Roox, o.c., IR DI 2008, I2 e.v.

267. Zie over de relevante bepalingen terzake in de Handhavingsrichtlijn de bespreking van C. De Meyer, 'Het bevel tot staken naar Belgisch recht', in Sancties en procedures in intellectuele rechten, I94 e.v.

268. M.C. Janssens, o.c. in Sancties en procedures in intellectuele rechten, 47.

269. Zie de bedenkingen van C. De Meyer, o.c., Sancties en procedures in intellectuele rechten, 205-206. 
Daarnaast ${ }^{270}$ heeft elke houder van een intellectueel recht de mogelijkheid om een stakingsvordering zoals in kort geding in te stellen. De procedure wordt gevoerd voor de voorzitter van de rechtbank van koophandel met de voordelen die inherent zijn aan een kort geding procedure, zijnde een snelle behandeling van de zaak en de uitvoerbaarheid bij voorraad van de beslissing. ${ }^{271}$ De voorzitter zal niettemin een eindbeslissing nemen over de namaak en de staking en spreekt zich dus ten gronde uit, zodat de nadelen van het kort geding worden vermeden. ${ }^{272}$

De stakingsvordering zoals in kort geding werd door de wet van Io mei 2007 opgenomen in het gewijzigde artikel 96 s I WHPC. Het vroeger artikel 96 WHPC sloot de mogelijkheid uit om op grond van artikel 95 WHPC een vordering tot staken in te stellen wegens inbreuken op intellectuele rechten. ${ }^{273}$ In de praktijk werd die bepaling evenwel vaak omzeild door bijvoorbeeld artikel 93 WHPC in te roepen in het raam van een procedure ten gronde, als een toepassing van het leerstuk van de onrechtmatige daad. ${ }^{274}$ Ook het Grondwettelijk Hof oordeelde dat het kennelijk overdreven was om een efficiënt middel zoals de vordering tot staken te onthouden aan de rechthebbenden voor bepaalde soorten van inbreuken. ${ }^{275}$ Het wekt dan ook geen verbazing dat de wetgever in 2007 gekozen heeft om het verbod op samenloop tussen de intellectueelrechtelijke vorderingen en een vordering op grond van de WHPC op te heffen. De stakingsvordering vormt een belangrijk instrument inzake een efficiënte en tevens snelle handhaving van de intellectuele rechten.

Het nieuwe artikel 96 § I WHPC geeft de voorzitter van de rechtbank van koophandel de mogelijkheid om in het raam van een stakingsvordering kennis te nemen van elke inbreuk op een intellectueel eigendomsrecht zonder dat hij zich moet beroepen op een bepaling van de WHPC, met uitzondering van de geschillen inzake het auteursrecht, de naburige rechten, en de databankenrechten. Deze uitzondering is evenwel niet absoluut. ${ }^{276}$

Artikel 98 lid rbis WHPC bepaalt wie de vordering tot staken op grond van artikel 96 § I WHPC kan instellen: alle personen die volgens de bijzonder wetten betreffende het betrokken intellectueel eigendomsrecht de vordering inzake namaak kan instellen. Hierdoor is de wetgever afgeweken van de algemene regel in de WHPC

270. In de parlementaire voorbereiding wordt gesproken over een 'volwaardig alternatief'. Zie Parl. St., Kamer 2006-07, nr. 5I-2943/00I.

27I. B. Michaux en E. De Gryse, o.c., TBH 2007, 633; K. Roox, o.c., TBH 2007, 343.

272. B. Michaux en E. De Gryse, o.c., TBH $2007,633$.

273. Deze mogelijkheid bestond wel voor inbreuken op het auteursrecht en de naburige rechten en het recht van producenten van databanken.

274. Hierover: K. Roox, o.c., IR DI 2007, 343.

275. Grondwettelijk Hof nr. 97/2007, 27 juni 2007. Zie A. Puttemans, 'Action en cessation, Cour d'Arbitrage et droits intellectuels: d'où venons-nous, où en sommes-nous, où allons nous?', TBH 2002, 8I2.

276. De uitzondering is te wijten aan het feit dat voor de wijziging van art. 96 WHPC, zoals gezegd, de stakingsvordering reeds bestond voor deze rechten, maar die moest ingesteld worden voor de Voorzitter van de rechtbank van eerste aanleg. Niettemin moet rekening worden gehouden met de reeds geschetste wijziging in de bevoegdheidsverdeling, waardoor inbreuken op de Auteurswet voortaan toch soms voor de Voorzitter van de rechtbank van koophandel zullen komen. 
die bepaalt dat elke belanghebbende wiens belangen geschaad zijn, een vordering wegens schending van de eerlijke handelspraktijken kan instellen. ${ }^{277}$

De stakingsrechter kan het bestaan van de inbreuk vaststellen en de staking ervan bevelen. Meer nog, de stakingsrechter is daartoe verplicht van zodra hij vaststelt dat de inbreuk bestaat. Hij geniet in dit verband niet van enige beoordelingsmarge. ${ }^{278}$

Voorts kan de stakingsrechter op grond van artikel $96 \$ 3$ WHPC bijkomende maatregelen opleggen zoals het recht op informatie. Ook corrigerende maatregelen ${ }^{279}$ kunnen worden bevolen wanneer deze kunnen bijdragen tot de stopzetting van de vastgestelde inbreuk of van de gevolgen ervan, met uitzondering van de maatregelen tot herstel van de schade die door deze inbreuk wordt berokkend. Uit de wetten van 9 en ro mei 2007 blijkt het te gaan over de volgende maatregelen: de terugroeping uit het handelsverkeer, de definitieve verwijdering uit het handelsverkeer of de vernietiging van de inbreukmakende goederen, alsmede in passend geval, van de materialen en werktuigen die voornamelijk gebruikt worden bij het scheppen of vervaardigen van deze goederen. ${ }^{28 \circ}$ Bij het bevelen van dergelijke maatregelen laat de Europese wetgever wel marge voor een zekere opportuniteitscontrole. Hij zal volgens artikel Io $\S 3$ van de Richtlijn nr. 2004/48 rekening moeten houden met de evenredigheid tussen de ernst van de inbreuk en de corrigerende maatregelen, alsmede met het belang van derden.

De stakingsrechter kan onder dezelfde voorwaarden als bij de corrigerende maatregelen ook de bekendmaking van zijn beslissing bevelen. Hij kan voorts een dwangsom koppelen aan zijn stakingsbevel.

\subsubsection{Vordering tot schadevergoeding}

De wet van Io mei 2007 voorziet dat elke benadeelde van een inbreuk op een intellectueel eigendomsrecht het recht heeft om schadevergoeding te vorderen. Dit is uitdrukkelijk voorzien in alle intellectuele eigendomswetten ${ }^{28 \mathrm{r}}$ en is een toepassing van artikel $1_{3} 82 \mathrm{BW}$. Eenieder die op foutieve wijze aan een derde schade berokkent, moet die schade integraal vergoeden. De toepassing van artikel I382 BW onderstelt het bewijs van de fout van de aangesprokene, de schade en het oorzakelijk verband.

Wat het foutbewijs betreft, is er enige verwarring ontstaan in de rechtsleer. Recent werd nog verdedigd dat er sprake is van een objectieve aansprakelijkheid van de inbreukmaker, omdat hij noch door het bewijs van goede trouw noch door het bewijs van zorgvuldig gedrag aan aansprakelijkheid kan ontkomen. ${ }^{282}$ Dit strookt niet met de invulling die het Hof van Cassatie geeft aan de buitencontractuele fout, die

277. M.C. Janssens, o.c., in Sancties en procedures in intellectuele rechten, 48-49.

278. Conform art. II Richtlijn nr. 2004/48.

279. B. Van Reepinghen en L. Van Reepinghen, o.c., JT 2008, I59.

280. Hierover: B. Michaux en E. De Gryse, o.c., TBH 2007, 634.

28I. Art. 52 \$ 4 Octrooiwet, art. 86bis § I Auteurswet, art. 2.2I en 3.I7 BVIE, art. I2 quarter § I Databankenwet, art. 36 § I Kwekerswet, art. I3 § I Wet Topografieën en art. 2 Ibis § I WHPC.

282. In die zin: C. Ronse, 'De andere herstelmaatregelen en in het bijzonder de schadevergoeding', in Sancties en procedures in intellectuele rechten, 228-229. 
- zoals reeds uiteengezet - een subjectief element en een objectief element omvat. Het objectieve element betekent dat de schadeverwekker een onrechtmatige daad moet hebben begaan, door de schending van de algemene zorgvuldigheidsnorm of door de schending van een norm die een bepaalde gedragsregel bevat, hetzij een gebod, hetzij een verbod. Wanneer aldus een norm een bepaald gedrag gebiedt of verbiedt, is de loutere overtreding van die norm een buitencontractuele fout, ${ }^{283}$ op voorwaarde dat de schending wetens en willens gebeurde. ${ }^{284}$ Het Hof van Cassatie heeft dit principe onder meer bevestigd in een arrest van 3 oktober 1994 door te overwegen dat 'de materiële overtreding van een wets- of verordeningsbepaling op zichzelf een fout uitmaakt die leidt tot strafrechtelijke en burgerrechtelijke aansprakelijkheid van de dader, mits die overtreding wetens en willens is begaan'. ${ }^{285}$ Deze omschrijving werd letterlijk overgenomen door de wetgever. ${ }^{286}$ De loutere schending van een intellectuele eigendomswet maakt aldus een buitencontractuele fout uit, zonder dat er nog een zorgvuldigheidstoetsing moet gebeuren. ${ }^{287}$ Dit principe wordt toegepast in de rechtspraak. De rechtbank van eerste aanleg te Gent moest zich in het vonnis van Io januari 2007 uitspreken over de betwisting tussen twee producenten van kinderstoelen. Stokke bezit in België de auteursrechten op de zogenoemde Tripp Trapp-stoel, maar sinds 1994 verdeelde producent New Valmar onder dezelfde benaming kinderstoelen in de Benelux. Overeenkomstig artikel I Auteurswet heeft alleen de auteur van een werk van letterkunde of kunst het recht om zijn werk te reproduceren of om een derde te machtigen. De rechtbank stelde vast dat Stokke een dergelijke machtiging niet had verleend aan New Valmar, zodat de fout van laatstgenoemde vaststond door de loutere schending van deze wetsbepaling. ${ }^{288}$

Ook de schadebegroting kan tot discussie leiden. De Richtlijn nr. 2004/48 spreekt over een 'passend herstel', ${ }^{289}$ terwijl in het Belgische recht de regel van de integrale schadeloosstelling wordt toegepast. De rechtbank kan een reële schadevergoeding toekennen, ${ }^{290}$ zodat rekening zal worden gehouden met de winstderving door de houder van het recht of met de onrechtmatige winsten die werden gerealiseerd door de inbreukmaker. De beoordeling daarvan gebeurt in concreto. In het zonet besproken vonnis hield de rechtbank bij de berekening van de gederfde winst rekening met het feit dat Stokke wellicht niet alle door New Valmar verkochte stoelen had kunnen verkopen, gelet op het feit dat er op de Belgische markt enkele alternatieven bestaan voor de Tripp Trapp-stoel. De winstderving werd berekend op de helft van de door

\footnotetext{
283. R.O. Dalcq, Traité de la responsabilitécivile, I78; L. Cornelis, Beginselen van het Belgische buitencontractuele aansprakelijkheidsrecht, I, De onrechtmatige daad, Antwerpen, Maklu, I989, 59 e.v.

284. Cass. 3 oktober 1994, Arr.Cass. I994, 807; Cass. I7 november 2006, TRV 207, I38.

285. Cass. 3 oktober I994, Arr.Cass. I994, 807, JT I995, 26 en RW I996-97, I227, noot.

286. Parl.St. Kamer 2006-07, nr. 5I-2943/0oI en nr. 5I-2944/ooI.

287. B. Michaux en E. De Gryse, o.c., TBH 2007, 640; M.C. Janssens, o.c., RW 2007-08, 938.

288. Rb. Gent Io januari 2007, IR DI 2007, I3, noot F. Petillon.

289. Hierover: C. Ronse, o.c., in Sancties en procedures in intellectuele rechten, 235.

290. Zie M. Buydens, 'La réparation du dommage en droit de la propriété industrielle', TBH ı994, 448 e.v.
} 
New Valmar verkochte stoelen. Ook een forfaitaire schadevergoeding is mogelijk wanneer de schadevergoeding niet op een andere wijze kan worden gerealiseerd. ${ }^{29 I}$

\subsubsection{Alternatieve herstelmaatregelen}

De Belgische wetgever heeft niet stilgezeten. Naast de reeds geschetste mogelijkheden voor de benadeelde van een inbreuk op een intellectueel recht, werden voorts voor alle intellectuele rechten een aantal nieuwe maatregelen uitgewerkt. Soms betreft het een reeds voor een bepaald intellectueel recht bestaande maatregel, die uitgebreid werd tot alle intellectuele rechten.

De rechter kan de afgifte van de goederen bevelen, de goederen terugroepen uit het handelsverkeer en of bevelen dat zijn beslissing wordt gepubliceerd. Ook aan de informatieverstrekking heeft de Belgische wetgever bijzonder aandacht besteed, ervan uitgaande dat een inbreuk kan worden bestreden wanneer men over correcte informatie beschikt over de herkomst van de nagemaakte goederen en als men kan achterhalen wie betrokken was bij de productie ervan. ${ }^{292}$ Zo kan onder meer worden gevorderd dat de inbreukmaker de informatie met betrekking tot de herkomst van de goederen en alle daarop betrekking hebbende documenten meedeelt. ${ }^{293}$

Voorts werden enkele bijkomende burgerlijke sancties voorzien die enkel gelden wanneer er sprake is van kwade trouw. Dit is bijvoorbeeld het geval bij piraterij. In een dergelijk geval kan een vordering tor afdracht van de winst worden ingesteld. De winst die de inbreukmaker heeft genoten, moet bij wijze van schadevergoeding worden betaald en wordt daarop ook aangerekend. De rechter kan dan zelfs de burgerlijke verbeurdverklaring van de inbreukmakende goederen uitspreken, en in passend geval van de materialen en de werktuigen die bij de vervaardiging van die goederen zijn gebruikt en die nog in het bezit zijn van de verweerder.

\section{Mogelijkheden en grenzen van privaatrechtelijke handhaving}

\section{I Alomtegenwoordige klassiekers met een open karakter: nietigheid en onrechtmatige daad}

Het privaatrecht kent van oudsher bepalingen die strekken tot handhaving van 'de openbare orde en de goede zeden' evenals bepalingen die ertoe strekken om de zwakkere partijen bij het stellen van rechtshandelingen te beschermen (bepalingen van dwingend recht). Het aantal bepalingen van de laatste categorie is de afgelopen decennia toegenomen onder invloed van de maatschappelijke opvattingen die

29I. M.C. Janssens, o.c., RW 2007-08, 938.

292. M.C. Janssens, o.c., RW 2007-08, 938.

293. Art. 53 \ 3 Octrooiwet, art. 86ter $\S 3$ Auteurswet, art. I2quinquies $\S 3$ Databankenwet, art. 36 § 6 Kwekerswet, art. I4 § 3 Wet Topografieën en art. 2rbis § I WHPC. 
'nieuwe ongelijkheden' onderkennen, in het bijzonder in de verhouding tussen professionelen en consumenten, en deze wensen te compenseren door de zwakkere partij wettelijke rechten toe te kennen waarvan contractueel niet kan worden afgeweken (alleszins niet voor het betreffende recht opeisbaar is).

Contractuele afspraken die in strijd zijn met bepalingen van openbare orde of van dwingend recht zijn nietig. Aangezien de civiele sanctie van de nietigheid alle contractuele afspraken treft die in strijd zijn met de openbare orde en het dwingend recht, heeft zij een heel wijd toepassingsgebied dat zich uitstrekt over alle rechtstakken.

Een andere klassieke civielrechtelijke sanctie met een heel wijd toepassingsgebied is de onrechtmatige daad. Op deze grondslag kan eenieder vergoeding vorderen voor de schade die hij geleden heeft door de aan een ander toerekenbare inbreuk op om het even welke wettelijke bepaling die een bepaald gebod of verbod oplegt en zelfs voor elke overtreding van de zorgvuldigheidsnorm. De Schutznormtheorie is inderdaad vreemd aan het Belgische recht. Het aansprakelijkheidsrecht heeft weliswaar in de eerste plaats een compensatoir doel, maar het heeft tevens een preventieve, reglementerende of normatieve functie. Het zorgt enerzijds voor het afdwingen van de naleving van bestaande rechtsregels en leidt anderzijds tot het uitwerken van nieuwe gedragsregels.

Een belangrijk voordeel van deze twee meest klassieke privaatrechtelijke handhavingsmechanismen is dat zij door hun 'open karakter' kunnen worden aangewend om in te spelen op nieuwe sociale noden, zelfs voordat hieromtrent specifieke wetgeving is tot stand gekomen.

\subsection{Uitbreiding van het privaatrechtelijk sanctiearsenaal}

In bepaalde rechtsdomeinen heeft de wetgever evenwel een verdergaande privaatrechtelijke handhaving ingevoerd. Enerzijds heeft hij het privaatrecht meer bewust aangewend tot handhaving van bepaalde rechts- en/of gedragsnormen en anderzijds heeft hij het privaatrechtelijke sanctieapparaat versterkt door uitbreiding met nieuwe privaatrechtelijke sancties.

\subsubsection{Waarom kiezen voor bijkomende privaatrechtelijke rechtshandhaving?}

Een mooi voorbeeld van het meer bewust aanwenden van het privaatrecht als handhavingsmechanisme vinden we in het antidiscriminatierecht, waar de wetgever zich bij zijn keuze voor een uitbreiding van het privaatrechtelijke sanctiearsenaal liet leiden door de ontoereikendheid van de bestaande strafrechtelijke handhavingsmechanismen.

In andere rechtstakken neemt de Europese Unie het voortouw voor de versterking van het privaatrechtelijk sanctiearsenaal. Op het domein van de intellectuele eigendomsrechten lijken de Europese regels inzake bevoegdheden ertoe te hebben geleid dat in eerste instantie het privaatrechtelijk luik van het 'handhavingsplan' werd aangenomen. Het oorspronkelijke strafrechtelijke luik blijkt immers te zijn geschrapt 
nadat het Europees parlement erop wees dat dit tot de zoegenoemde 'derde pijler' behoorde.

Ook op het gebied van het mededingingsrecht is het de Europese Unie, en dan voornamelijk de Europese Commissie, die aanstuurt op een sterkere privaatrechtelijke handhaving. De houding van de Commissie lijkt in dit geval ingegeven te zijn, niet alleen door haar bekommernis om de schadelijders compensatie te bezorgen, maar ook door het bewustzijn dat zij over onvoldoende middelen beschikt om op eigen kracht te voorzien een optimaal handhavingsniveau.

\subsubsection{Welk type privaatrechtelijke handhavingsmechanismen?}

De vordering tot staking die voor het eerst werd ingevoerd in het recht inzake onrechtmatige mededinging bleek daar zeer succesvol en werd nadien uitgebreid tot tal van andere rechtsdomeinen, zoals het antidiscriminatierecht en de intellectuele rechten.

De wetgever is vaak ook bereid om de positie van de benadeelde te versterken door bijvoorbeeld te voorzien in een bescherming tegen represailles, zoals die is voorzien in de antidiscriminatiewetgeving, of door het invoeren van bijzondere regels die de bewijsvoering vergemakkelijken. Dit laatste geschiedde zowel in het antidiscriminatie- en handelspraktijkenrecht (omkering van de bewijslast) als in het recht inzake intellectuele eigendom (uitbreiding van de vordering tot beschrijven of het beslag van de namaak).

Om het slachtoffer dat moeite heeft om zijn schade te begroten tegemoet te komen, werd zowel in de antidiscriminatiewetgeving als in het recht inzake intellectuele eigendom voorzien in de mogelijkheid van een forfaitaire schadevergoeding. Hiermee wordt enigszins afgestapt van het zuiver compensatoire denken.

Een nog meer spectaculaire afwijking van het compensatoire denken vond evenwel reeds plaats met de invoering bij wet van $3 \mathrm{I}$ januari 1980 van de dwangsom in

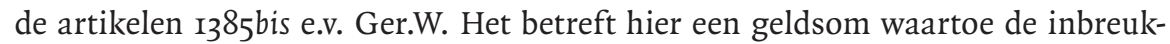
pleger op verzoek van de benadeelde kan worden veroordeeld voor het geval aan de hoofdveroordeling niet wordt voldaan. Eenmaal verbeurd, komt zij toe aan degene op wiens verzoek ze werd opgelegd (art. 1385quater BW). Het betreft dus een privaat dwangmiddel tot nakoming van de gerechtelijke veroordeling. ${ }^{294}$ De dwangsom heeft op grond van haar regeling in het gerechtelijk wetboek reeds een ruim toepassingsgebied. Haar toepasselijkheid werd in de antidiscriminatiewetten nog eens uitdrukkelijk bevestigd en uitgebreid.

Bijzonder drastisch is ook de sanctie van artikel 94/I4 \$ 2, lid 2 WHPC dat de consument die het slachtoffer is geworden van bepaalde ernstige oneerlijke handelspraktijken, zoals het beweren dat een product het winnen bij kansspelen kan vergemakkelijken, het recht geeft om, binnen een redelijke termijn vanaf het moment dat hij kennis had of hoorde te hebben van het bestaan ervan, de terugbetaling te eisen

294. In deze zin K. Wagner, Dwangsom, Mechelen, E. Story-scientia, 2003, nr. I5, p. I7. 
van de betaalde sommen zonder dat hij verplicht is tot teruggave van het reeds geleverde product of de reeds geleverde dienst. ${ }^{295}$ Ook wanneer de consument slachtoffer is geworden van andere oneerlijke handelspraktijken, kan de rechter overigens, indien hij dit passend acht, op grond van artikel 94/I4 $§ 2$ lid 3 WHPC de terugbetaling bevelen van reeds door de consument betaalde sommen, zonder de consument tot teruggave van het reeds geleverde product of de reeds geleverde dienst te verplichten.

Een andere illustratie van het verlaten van het louter compensatoire denken vindt men in de mogelijkheid tot het bevelen van afdracht van winst of van de burgerlijke verbeurdverklaring, die zijn ingevoerd in het recht inzake de intellectuele eigendom. Voor andere specifieke sancties in verband met intellectuele eigendom verwijzen wij naar onze uiteenzetting hierboven.

Regelmatig treft men ook de mogelijkheid aan om de publicatie van het vonnis te vorderen, met name in het recht inzake handelspraktijken en de intellectuele eigendom.

\subsection{Doelmatigheid van privaatrechtelijke handhaving}

Privaatrechtelijke handhaving functioneert goed waar het gaat om schendingen van rechten tussen min of meer gelijke partijen, bijv. concurrenten. Aangezien concurrenten of professionelen in het algemeen, repeat players zijn, en zij ook in de toekomst met gelijkaardige problemen geconfronteerd dreigen te worden, is de stakingsvordering in dit soort verhoudingen zeer geliefd. De stakingsvordering leidt immers tot het opleggen van een verbod om een bepaalde rechtsschending te laten voortduren of opnieuw te plegen in de toekomst, eventueel op straffe van verbeurte van een dwangsom. De nietigheid van bedingen die in strijd zijn met wetsbepalingen van openbare orde of van dwingend recht wordt voornamelijk gebruikt als verweermiddel in een tegen een contractspartij ingestelde procedure. Buitencontractuele vorderingen tot schadevergoeding wegens schendingen van het mededingingsrecht komen niet frequent voor. Andere buitencontractuele vorderingen zijn uiteraard wel talrijk, en vooral de buitencontractuele vordering wegens medeplichtigheid aan andermans contractbreuk komt tussen concurrenten regelmatig voor. De vordering tot staking is echter zeker zo populair als de vordering tot schadevergoeding.

Indien een sterkere partij de rechten schendt van een zwakkere partij, ligt privaatrechtelijke handhaving moeilijker. Zwakkere partijen zijn vaak niet zo goed op de hoogte van hun rechten, of zien af van gerechtelijke stappen omdat de waarde van de zaak niet opweegt tegen de kosten van de procedure. Aan de ongelijke positie van de consument in zijn verhouding tot de professioneel wordt deels tegemoet door de rechter de bevoegdheid te verlenen de nietigheid van bedingen die indruisen tegen de consumentenwetgeving ambtshalve op te werpen, of door aan belangenorganisaties of overheidsinstanties een vorderingsrecht te verlenen. Aangezien consumenten

295. Dit geldt ook voor consumenten die het slachtoffer worden van de handelspraktijken bedoeld in art. $98 / 8, \mathrm{I}^{\circ}$ en $94 / \mathrm{II}, 2^{\circ}$ en $7^{\circ} \mathrm{WHPC}$. 
of privépersonen veelal geen repeat players zijn, in die zin dat zij maar eenmaal een bepaald contract (willen) sluiten met een bepaalde wederpartij is de vordering tot staken voor hen veelal niet zo geschikt. ${ }^{296}$ Het ligt meer voor de hand dat zij wordt ingesteld door een consumentenorganisatie die een bepaald laakbaar gedrag in de verhouding tot andere consumenten in de toekomst wil voorkomen. Consumenten zelf zijn meer gediend met een vordering tot schadevergoeding. ${ }^{297}$ Schadevergoeding kan in beginsel evenwel slechts worden gevorderd in een klassieke procedure ten gronde. In het antidiscriminatierecht werd echter aan de stakingsrechter het recht toegekend om in een procedure zoals in kort geding een (beperkte) forfaitaire schadevergoeding toe te kennen. Bepaalde ernstige schendingen van de rechten van zwakkere partijen zijn bovendien strafrechtelijk gesanctioneerd (o.a. in het antidiscriminatie- en consumentenrecht).

\subsection{Inconsistenties tussen de schadevergoedingsfunctie en de handhavingsfunctie?}

Kunnen vorderingen tot schadevergoeding geen nadelige impact hebben op de (publieke) rechtshandhaving? Men kan argumenteren dat de overheid die een effectieve handhaving van de door haar opgelegde regels beoogt, op grond van een economische analyse dient te voorzien in sancties die, rekening houdende met de pak- en veroordelingskans, voldoende ontradend werken. Om ontradend te werken, dient de sanctie in principe zo te worden bepaald dat zij minstens gelijk is aan het omgekeerde van de pak- en veroordelingskans vermenigvuldigd met de door de wetsovertreding beoogde winst. Voor onopzettelijke handelingen zal het optimale niveau van zorgvuldigheid door de potentiële wetsovertreder worden bereikt indien de sanctie gelijk is aan het omgekeerde van de pakkans vermenigvuldigd met de door de wetsovertreding beoogde winst. Indien de wetsovertreder bijkomend schadevergoedingen moet betalen, dan wordt hij aangespoord om een hoger dan efficiënt niveau van zorgvuldigheid na te streven, hetgeen betekent dat hij kosten zal maken die buiten verhouding zijn tot het welvaartssurplus dat zij opleveren. ${ }^{298} \mathrm{De}$ oplossing van dit conflict lijkt in de regel echter niet te moeten worden gezocht in het ontzeggen aan de rechtsonderhorigen van hun recht op schadevergoeding, maar in het verrekenen van de te verwachten schadevorderingen bij het bepalen van de door de overheid op te leggen sanctie.

296. De consument blijkt inderdaad slechts uiterst zelden gebruik te maken van de stakingsvordering, zie I. Demuynck, 'Rechtshandhaving door de stakingsrechter', RW 200I-02, nr. 37, p. I245. Zie ook M. Dambre, 'De individuele consument en de vordering tot staken voor inbreuken op de Wet Consumentenkrediet', (noot onder Vz. Kh. Brussel 4 november I997), JHPM I997, 55I; P. Devroede, Y. Merchiers en I. Demuynck, 'Overzicht van rechtspraak. Algemeen handelsrecht, handelspraktijken en consumentenbescherming (I992-I997), TPR I999, nr. 633, p. 5II.

297. I. Demuynck, 0.c., RW 200I-02, nr. 37, p. I245.

298. Vgl. A.M. Mitchell Polinski en S. Shavell, 'Punitive Damages: an Economic Analysis', Harvard Law Journal i998, 870 e.v. 
In het mededingingsrecht stelt zich bovendien het probleem dat een toenemende privaatrechtelijke rechtshandhaving door middel van vorderingen tot schadevergoeding het clementiebeleid van de Commissie en de nationale mededingingsautoriteiten kan doorkruisen. ${ }^{299}$ Omdat kartels bijzonder moeilijk op te sporen zijn zolang alle bij de verboden mededingingsrechtelijke afspraak betrokken partijen het zwijgen bewaren, trachten de Europese Commissie en de Belgische mededingingsautoriteiten de bij een kartel betrokken partijen te verleiden om het kartel aan te geven bij de bevoegde nationale mededingingsautoriteit. ${ }^{300}$ Daartoe beloven de betrokken mededingingsautoriteiten clementie, vrijstelling van boetes aan de bij een kartel betrokken partij die als eerste informatie en bewijsmateriaal met betrekking tot het kartel verschaft aan de bevoegde mededingingsautoriteit. Ook aan latere clementieverzoekers kan een, eventueel gedeeltelijke, vrijstelling van boetes worden verleend indien zij belangrijk bijkomend bewijsmateriaal verschaffen omtrent het kartel. ${ }^{301}$

In de huidige stand van het recht, zijn de gevolgen van het verkrijgen van clementie inderdaad beperkt tot een gehele of gedeeltelijke vrijstelling van boetes. De mededingingsautoriteit kan de partij die om clementie verzoekt geen vrijstelling verlenen van haar aansprakelijkheid tot het betalen van (haar aandeel in) de veroorzaakte schade. ${ }^{302}$ Vooralsnog was het risico op een schadeclaim jegens een clementieverzoeker beperkt. Wanneer het risico op schadeclaims toeneemt ten gevolge van de promotie van privaatrechtelijke afdwinging van het mededingingsrecht bestaat evenwel het risico dat bij een kartel betrokken partijen minder snel een verzoek tot clementie zullen indienen, hetgeen de opsporing en bestraffing van kartels zou bemoeilijken. De vraag rijst of men de clementieverzoeker, ter vrijwaring van het succes van de clementieprocedure, een vrijstelling van aansprakelijkheid jegens de schadelijders dient te verlenen. ${ }^{303}$ Een mogelijke oplossing van dit conflict voor België zou erin kunnen bestaan om de clementieverzoeker vrij te stellen van zijn aansprakelijkheid in de onderlinge verhouding tussen de bij het kartel betrokken partijen. Jegens het slachtoffer, dat geen partij is bij het kartel, kunnen alle deelnemers aan het kartel in solidum gehouden blijven. Een verdergaande stap zou erin kunnen bestaan te bepalen dat het aandeel van de clementieverzoeker in de schade verdeeld wordt over de andere bij het kartel betrokken partijen én dat de benadeelden geen

299. Bepaalde auteurs achten clementie en private handhaving onverzoenbaar, zo bijv. C. Hodges, 'Competition enforcement, regulation and civil justice: what is the case?', CMLRev. 2006, I390. Zie ook E. Combes, 'A la recherche de la sanction optimale', Concurrences 2006, I4.

300. Mededeling van de Commissie betreffende immuniteit tegen geldboeten en vermindering van geldboeten in kartelzaken, $\mathrm{Pb} C 8$ december 2006, afl. 298, p. I7, nr. 3; art. 49 WBEM, Mededeling van de Raad voor de Mededinging betreffende volledige of gedeeltelijke vrijstelling van geldboeten in kartelzaken, BS 22 oktober 2007, nr. 3.

30I. Mededeling van de Commissie inzake clementie, nr. 8 e.v. en 23 e.v.; Mededeling van de Raad voor de Mededinging inzake clementie, nr. I5 e.v.

302. Mededeling van de Commissie inzake clementie, nr. 39; Mededeling van de Raad voor de Mededinging, nr. $9 .$.

303. Zie ook opties 28-30 Groenboek; Witboek, II-I2; T. Eilmansberger, 'The green paper on damages actions for breach of the EC antitrust rules and beyond: Reflections on the utility and feasibility stimulating private enforcement through legislative action', CMLRev. 2007, 435 e.v.; A.P. Komninos, 'The EU White Paper for damages actions: A first appraisal, Concurrences 2008, nr. 26 e.v., p. 89 e.v. 
vordering mogen instellen tegen de clementieverzoeker in de mate waarin hij de namen bekend maakt van andere bij het kartel betrokken partijen die voldoende solvabel zijn.

\section{Conclusie}

De 'rechtshandhavingsfunctie' van het privaatrecht is de laatste jaren vooral onder de aandacht gebracht door de Europese Commissie die de privaatrechtelijke handhaving van het mededingingsrecht wil aanmoedigen. In de mededingingsrechtelijke doctrine wordt hieromtrent uitvoerig gedebatteerd. In Nederland, werd deze discussie uitgebreid tot de vraag die het privaatrecht in het algemeen kan spelen bij de rechtshandhaving. In de Belgische privaatrechtelijke doctrine was deze vraag in haar algemeenheid nog niet aan bod gekomen. Dit is op zich reeds een merkwaardige vaststelling.

Bij nader onderzoek blijkt evenwel dat de wetgever zich in een aantal sociaaleconomische domeinen wel degelijk de vraag heeft gesteld naar de effectiviteit van het privaatrecht als handhavingsmechanisme. In bepaalde van deze domeinen heeft de wetgever ook bewust ingezet op een sterkere privaatrechtelijke handhaving omdat de publiekrechtelijke, vaak strafrechtelijke handhaving ondoeltreffend (antidiscriminatierecht) of overbodig (handelspraktijkenrecht in de verhouding tussen concurrenten) bleek. Uit de parlementaire voorbereiding van de antidiscriminatiewetgeving blijkt dat de handhavingsfunctie van het privaatrecht niet louter als een nevenwerking werd beschouwd, maar dat het privaatrecht bewust werd ingeschakeld met het ook op een hoger niveau van rechtshandhaving. Dit lijkt ook het geval te zijn op het gebied van de intellectuele rechten. Ook de handhaving van het consumenten- en handelspraktijkenrecht geschiedt voornamelijk via privaatrechtelijke weg.

Tot de privaatrechtelijke handhavingsmechanismen behoren de nietigheid, de klassieke contractuele remedies (nakoming, ontbinding, schadevergoeding, exceptio non adimpleti contractus) en de buitencontractuele aansprakelijkheid leidend tot een schadevergoeding in geld of in natura. Ook andere privaatrechtelijke leerstukken zoals het verbod van rechtsmisbruik en de burenhinder kunnen een rol spelen bij de rechtshandhaving. Een uiterst belangrijk middel van privaatrechtelijke rechtshandhaving is verder de vordering tot staking, die haar oorsprong vindt in het recht inzake de oneerlijke handelspraktijken, maar thans in tal van andere rechtsdomeinen is ingevoerd. Een veroordeling door de burgerlijke of handelsrechtbanken kan bovendien kracht worden bijgezet door het opleggen van een dwangsom. In bepaalde rechtsdomeinen werden verder nog specifieke privaatrechtelijke handhavingsmechanismen ingevoerd, zoals het recht van antwoord in verband met persoonlijkheidsrechten en publicatie van het vonnis in het recht inzake handelspraktijken en intellectuele rechten en de vordering tot winstafdracht of de burgerlijke verbeurdverklaring bij inbreuken op intellectuele rechten. Regelmatig werd ook de positie van het slachtoffer, de eisende partij versterkt. Zo werkt men in het antidiscriminatierecht met een omkering van de bewijslast en wordt de bewijsvoering in 
zaken betreffende intellectuele rechten vergemakkelijkt door de bijzondere procedure van de vordering tot beschrijving/het beslag van de namaak. In het antidiscriminatierecht werd bovendien zowel voor het slachtoffer als voor de getuigen voorzien in een bescherming tegen represailles.

Hoe valt de inschakeling van het privaatrecht als handhavingsmechanisme te beoordelen? In se lijkt het verstandig om de privaatrechtelijke rechtspersonen die nadeel ondervinden van onrechtmatig handelen op een actieve wijze bij de handhaving te betrekken en hen de middelen in handen te geven om zelf het initiatief te kunnen nemen om het onrechtmatig handelen te doen ophouden of zelfs te voorkomen. Hierbij dient er uiteraard wel zorg voor te worden gedragen dat de rechten van de verdediging worden gerespecteerd. Aangezien de effectieve afdwinging van de in deze bijdrage bedoelde privaatrechtelijke handhaving berust op een tussenkomst van de gewone rechtbanken lijkt dit in principe te zijn gegarandeerd. Blijvende waakzaamheid is evenwel geboden, bijvoorbeeld in het kader van de eventuele invoering van collectieve acties voor het verkrijgen van schadevergoeding.

Privaatrechtelijke rechtshandhaving blijkt beter te werken in relaties tussen gelijken, in het bijzonder professionelen dan in relaties tussen een sterkere en een zwakkere partij, al stelt men vast dat het recht de zwakkere partij soms ter hulp komt door de rechter de mogelijkheid te bieden om een zelfs relatieve nietigheid ambtshalve op te werpen, door het slachtoffer en de getuigen een bescherming te bieden tegen represailles of door een vorderingsrecht toe te kennen aan belangenorganisaties.

In bepaalde gevallen, bijvoorbeeld in het mededingingsrecht, zullen zelfs professionele partijen niet over voldoende opsporingsmogelijkheden of incentives beschikken om op zichzelf in een afdoende handhaving te voorzien.

In andere gevallen, bijvoorbeeld in het milieurecht, zal het gewenste zorgvuldigheids of beschermingsniveau beter bereikt kunnen worden via specifieke administratiefrechtelijke regulering bijv. inzake vergunningen dan via de dreiging met schadevergoedingsacties en andere gemeenrechtelijke privaatrechtelijke leerstukken.

De overheid blijft overigens verantwoordelijk voor de bescherming van het algemeen belang. Waar de privaatrechtelijke rechtshandhaving ontoereikend blijkt om het gewenste beschermingsniveau te bereiken, dient de overheid in te grijpen, hetzij om een meer effectieve privaatrechtelijke rechtshandhaving mogelijk te maken, hetzij door deze aan te vullen met publiekrechtelijke rechtshandhaving.

Privaatrechtelijke rechtshandhaving lijkt derhalve een goede aanvulling te kunnen vormen op, maar niet geheel in de plaats te kunnen treden van publiekrechtelijke rechtshandhaving. 